MONOGRAPHIAE B O T A N I A E Vol. 69, 1986

WIESŁAW FAŁTYNOWICZ

\title{
THE DYNAMICS AND ROLE OF LICHENS IN A MANAGED CLADONIA-SCOTCH PINE FOREST (CLADONIO-PINETUM)
}
Dynamika i rola porostów w zagospodarowanym borze chrobotkowym (Cladonio-Pinetum)

Redaktor: Romuald Olaczek

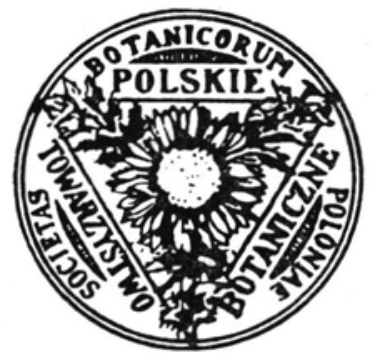




\section{Wydano z pomocą finansową}

Polskiej Akademii Nauk

\section{KOMITET REDAKCYJNY}

R. Olaczek (Łódź), E. Sidorkiewicz (Warszawa)

\section{RADA REDAKCYJNA}

W. Matuszkiewicz (Warszawa), Z. Podbielkowski (Warszawa), E. Sidorkiewicz (Warszawa), R. Olaczek (Łódź), H. Piotrowska (Gdańsk), K. Rostański (Katowice), W. Żukowski (Poznań)

ADRES REDAKCJI: Al. Ujazdowskie 4, 00-478 Warszawa

Copyright by Państwowe Wydawnictwo Naukowe Warszawa 1986

ISBN 83-01-06168-5

ISSN 0077-0655

\section{PANSTWOWE WYDAWNICTWO NAUKOWE}

Nakład $390+90$ egz. Ark. wyd. 8,25. Ark. druk. 6,0+wkl. Papier druk. sat. kl. III, 80 g. $70 \times 100 \mathrm{~cm}$. Oddano do składania we wrześniu $1985 \mathrm{r}$. Podpisano do druku w czerwcu $1986 \mathrm{r}$. Druk ukończono w lipcu 1986 r. Zam. 3403/85. Cena zl 160,- 


\section{CONTENTS}

1. INTRODUCTION . . . . . . . . . . . . . . . . . 5

2. GENERAL COMMENTS ON THE METHODS USED . . . . . . $\quad 7$

3. CHARACTERISTICS OF THE STUDIED AREA . . . . . . . . $\quad 8$

3.1. Location, geomorphology and soils . . . . . . . . . . . . 8

3.2. Water regime and climate . . . . . . . . . . . . . 11

3.3. Vegetation . . . . . . . . . . . . . . . . . . . . . . 12

4. THE NATURE AND GENERAL EFFECTS OF ANTHROPOPRESSURE 13

4.1. Man's influence in the past . . . . . . . . . . . . . 13

4.2. Present-day methods of forest management and their significance in habitat formation , . . . . . . . . . . . . . 16

4.2.1. Traditional cultivation methods . . . . . . . . . . . 16

4.2.2. Hylomelioration . . . . . . . . . . . . . . . . . . . $\quad . \quad 20$

5. CHARACTERISTICS OF THE LICHEN FLORA . . . . . . . . 22

5.1. The distribution of species . . . . . . . . . . . . . . . . 22

5.2. Habitat groups . . . . . . . . . . . . . . . . . 23

5.2.1. Terricolous lichens . . . . . . . . . . . . . . . 23

5.2.2. Epiphytic lichens and decaying wood . . . . . . . 24

5.2.3. Epilithic lichens . . . . . . . . . . . . . . . $\quad 25$

6. COMMUNITIES CONTAINING LICHENS . . . . . . . . . . . . . $\quad 25$

6.1. Cladonio-Pinetum . . . . . . . . . . . . . . . . . . . . . . . . .

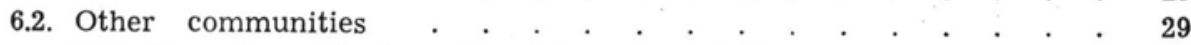

6.2.1. Leucobryo-Pinetum, Vaccinio uliginosi-Pinetum and raised bogs 29

6.2.2. Heaths and psammophilous swards . . . . . . . . . . . 52

7. CHANGES IN THE LICHEN FLORA BROUGHT ABOUT BY NATURAL AND ANTHROPOGENIC FACTORS . . . . . . . . . . . . . . 36

7.1. Changes taking place with the growth of pine stands . . . . $\quad 36$

7.1.1. Terricolous lichens . . . . . . . . . . . . . . 36

7.1.2. Epiphytic lichens on Pinus silvestris . . . . . . . . 43

7.1.3. Lichens of decaying pine stumps . . . . . . . . . . . . 49

7.2. Changes in the lichen flora resulting from mineral fertilization 64

7.2.1. Floristic relationships in the Cladonia-pine forest phytocenosis 64

7.2.2. The biomass of the herb and moss-lichen layers . . . . 74

7.3. Changes in the lichen flora under the influence of other anthropogenic factors . . . . . . . . . . . . . . . . . . 76

7.3.1. The introduction of underbrush . . . . . . . . . . 76

7.3.2. Litter-raking and grazing . . . . . . . . . . . . . . . . $\quad . \quad 79$

8. SUMMARY AND CONCLUSIONS . . . . . . . . . . . . . . . . $\quad . \quad 81$

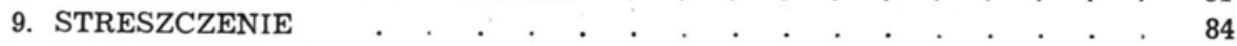

10. REFERENCES 


\begin{abstract}
Wiesław Faltynowicz. The dynamics and role of lichens in a managed Cladonia-Scotch pine forest (Cladonio-Pinetum). Monogr. Bot., vol. 69, 1986

The Cladonia-Scotch pine forest is a community seriously endangered by man's influence. Secondary succession in the Cladonio-Pinetum habitat is discussed and four stages of succession are distinguished. These are correlated with the succession of cryptogamous plants, mainly lichens, on decaying pine stumps and on pine trunks. The effects of the most common methods in forest management on the floristic composition, the phytocenotic structure and the biomass of the Cladonio-Pinetum herb and moss-lichen layers have been investigated. The include mineral fertilization, introduction of underbrush, grazing and litter-raking. These methods are shown to have on adverse effect on lichen growth. Also presented is an analysis of the lichen flora and the characteristics of the more important plant communities containing lichens in the north-western part to the Bory Tucholskie woodland (northern Poland).
\end{abstract}

Key words: lichens ecology, Cladonia-Scotch pine forest, succession, mineral fertilization, man's influence. 


\section{INTRODUCTION}

Forests are the most diverse land ecosystems; they are particularly abundant in living organisms and habitats, and under natural conditions make up a complex, self-regulating "mechanism". As opposed to such anthropogenic systems as meadows or tilled fields, forest climax ecosystems in the temperate zone require no artificial energy input for their continued existence (E 1 l e n berg 1978). Nevertheless, for some considerable time now, man's influence on all ecosystems has been so great that it is taking on a superorganic aspect.

For many hundreds of years, and during the 19th and 20th centuries in particular, natural forests have been degraded and transformed. The last forty or fifty years have seen the rapid expansion of man's activities in forests, among these the application of more intensive methods of cultivation. These restrict the self-sufficiency of forest ecosystems and frequently make the biological balance dependent on man's interference.

The majority of Cladonia-pine forests in Poland are the result of changes which took place after the degeneration of the forest ecosystem, a situation which was not remedied by any compensatory action on the part of man. The changeover from extensive to intensive forest managment has meant an increasing variety of cultivatory and hylomelioration measures in dry pine forest habitats. These measures have often brought about unforseen, adverse changes in forest ecosystems which could have been avoided, had they been preceded by rigorous, wideranging studies. It is a common opinion in forestry that the content and structure of the tree stand and perhaps the underbrush are of greatest if not exclusive importance to the forest and its habitat $(\mathrm{Obminski}$ 1977). Meanwhile, the vegetation of the "forest floor" frequently plays a no less important role as co-partner in the forest-forming process.

In dry pine forests, lichens are spatially and biologically dominant in most patches of the ground cover and are responsible for the characteristic appearance of the ground layer. Communities with large numbers of lichens have been studied in detail especially in areas where they

Received: January 24, 1983. Accepted: April 6, 1984. 
are widespread and of economic importance, such as the tundra of Europe and North America (cf. W i elgolaski (ed.) 1975, Tieszen (ed.) 1978 and others), and as the taiga (cf. A hti, Hepburn 1967).

In Poland, the number of lichens and their diagnostic usefulness in mature Cladonia-pine forest phytocenoses are well known, thanks mainly to the work of Tobolewski (1963), Wojterski (1964), Zi.elińska (1967), C zerwiński (1970), Sokołowski (1970a), C i eśliński (1979), but also to many other floristic and phytosociological papers (cf. Fałtynowicz 1983). There is, however, very little information on the numbers and changes in the lichen flora during the particular stages of the secondary succession leading up to Cladonia-pine forest, not to mention the lack of studies on the effect of various cultivatory measures on the lichen flora. This thesis is therefore an attempt to at last partially fill this gap.

The primary aim of this work was to present the numbers of lichens and their succession in the consecutive stages of the development of a Cladonia-pine forest, from tree-felling through pine plantations up to mature coniferous woodland phytocenoses. The ground, epiphytic and epixylic flora was analysed. During the study, careful attention was paid to the effect of traditional methods of cultivation in plantations, boskets and tree stands on the qualitative and quantitative relationships obtaining among the vegetation of the herb and moss-lichen layers, pine bark and decaying pine stumps. The use of intensive methods in forest husbandry, such as mineral fertilization and the introduction of undergrowths, provided an important incentive to study the effect of such measures on the lichen flora in Cladonia-pine forests. The results of preliminary investigations indicate changes resulting from primitive forest utilization, such as cattle grazing and the raking of forest litter, and these are included in order to demonstrate the influence of all the more important methods of cultivation on the vegetation in dry pine forests.

The study area, that is the north-western part of the Bory Tucholskie woodland, was eminently suitable for the realization of the aims mentioned above. Dry pine forests, which cover the larger part of this area, are a fairly simple forest ecosystem; this fact considerably facilitates this kind of study. There are a large number of lichen species and they play a significant part in this ecosystem. The extensive homogeneous surface enables many repetitions to be made. Apart from this, it is an area typical of most pine woodland in Poland as regards forest management principles and methods of cultivation, so the results of this study are representative of the dry pine forest phytocenoses which are so widespread on the Polish lowlands (about $8 \%$ of the total forest cover - Z a rę b a 1976).

Lichenological studies of the north-western part of the Bory Tuchol- 
skie, and also, in fact, the whole of this extensive woodland area are very few. This thesis contains the first detailed floristic material from this region of Western Pomerania.

It is my pleasant duty to express my gratitude to all those people who helped me during the collection and analysis of the material. I am particulary indebted to Prof. Hanna Piotrowska for her continued help and guidance throughout the compilation of this thesis; to Prof. Zygmunt Tobolewski for checking the accuracy of identification of most of the lichen species and for identifying some of the taxons; to Prof. Jerzy $\mathrm{F} \mathrm{abiszew} \mathrm{ski} \mathrm{for} \mathrm{his} \mathrm{valuable} \mathrm{comments} \mathrm{and} \mathrm{for} \mathrm{making}$ available to me his extensive library; to Prof. Zbigniew Prusinkiewicz for enabling me to carry out some of my research under his guidance and for his encouragement to take up and continue research into new topics; to Prof. Jan Bystrek for checking the accuracy of identification of all the taxons from the genera Bryopogon and Usnea and for identifying some of them; to $\mathrm{Dr}$ Józef $\mathrm{Szmeja}$ for his very helpful comments during the analysis of the material; to Dr Jacek H e rbi ch for taking some of the photographs; to Dr Ryszard Markow$\mathrm{ski}$ for making his phytosociological records of heaths available to me; and to Mrs Joanna Picinska-Fałtynowicz for drawing the figures.

\section{GENERAL COMMENTS ON THE METHODS USED}

As this thesis covers quite a wide range of topics, nearly all of which require different study methods, these will be discussed in detail in the appropriate chapters. At this point, I shall limit myself to a few general comments.

The studies were carried out from 1974 to 1980. A number of problems were worked out in cooperation with the Department of Soil Science of the Nicholas Copernicus University in Torun as part of their research project No. WE-09.10.01.02.05., coordinated by the Forestry Research Institute.

Phytosociological records of Cladonia-pine forest, moist pine forest, turf and heath phytocenoses were made according to the Braun-Blanquet method ( $\mathrm{Paw}$ a ow ski 1972). Each record in the dry pine forest habitat covered an area of $150 \mathrm{~m}^{2}$, in other communities the areas varied. About 400 records were made during the whole research period, most of which have been used in this thesis. The phytosociological tables were compiled according to the usual methods (S c a m on i 1967; P a w łow$\mathrm{ski}$ 1972). In the tables, sporadic species are those which occurred in one record only. Forest districts and other places are indicated in the tables by the following abbreviations: 


$\begin{array}{ll}\mathrm{A} & \text { - Antoniewo } \\ \mathrm{Db} & \text { - Dąbrowa } \\ \mathrm{L} & \text { - Laska } \\ \text { Leg } & \text { - Legbąd } \\ \text { Leś } & \text { - Leśno } \\ \text { Lub } & \text { - Lubnia } \\ \mathrm{P} & \text { - Parzyn }\end{array}$

Pop - Popówka
Prz $\quad$ - Przymuszewo
Sz $\quad$ - Szumiąca
W $\quad$ - Widno
WK - Wdzydze Kiszewskie
WT - Wdzydze Tucholskie

Vascular plants have been named according to the key in "Rośliny polskie" by Szafer et al. (1969), bryophytes according to Reyment-Grochowska (1950a) and Ochyra and Szmajda (1978). The nomenclature of lichens is as in the papers by Motyka (1960, 1962, 1964), and Nowak and Tobolewski (1975), with the exception of the genus Bryopogon (B ystrek, Górzyńska 1976) and Physcia s.l. (M o b e r g 1977).

The phytosociological records and herbarium specimens of lichens referred to in this thesis are to be found at the Department of Plant Ecology and Nature Protection of the University of Gdańsk.

\section{CHARACTERISTICS OF THE STUDIED AREA}

\subsection{LOCATION, GEOMORPHOLOGY AND SOILS}

The Bory Tucholskie are one of the largest tracts of woodland in Poland and the most extensive in Western Pomerania. Their overall area is around $1170 \mathrm{~km}^{2}$ (K o n dracki 1981). Their geobotanical, geomorphological and geological separateness, also the large area of this woodland, were the reasons for distinguishing the Bory Tucholskie in the geobotanical division of Poland as a District belonging to the Pomeranian Southern Transitional Zone ( $\mathrm{Sz}$ a f e $\mathrm{r}$ 1972). In the physicogeographical division of the country, the section of the Bory Tucholskie studied is part of the Charzykowo Plain mesoregion (Kondracki 1981).

The Przymuszewo Forestry Inspectorate (F.I.) is the most northwestern part of the Bory Tucholskie. It lies along the borders of three voivodships: Bydgoszcz, Gdańsk and Słupsk. The studied area is bounded to the west by the river Kłoniecznica and Brda, to the south by the rivers Brda and Niechwaszcz, to the east by the river Wda, and to the north by the channel of Lake Młosino Duże, the edge of the moraine upland near the village of Radun and Lakes Sumińskie and Kielskie (Figs. 1, 2), a total of some $200 \mathrm{~km}^{2}$.

The studied area, as indeed nearly all of the Bory Tucholskie, is situated on an outwash plain formed during the Pomeranian stage of the Baltic glaciation in a terminal moraine outwash area. The outwash plain is traversed by numerous lake channels. A significant feature of the landscape are moraine uplands with stretches of terminal moraine, e.g. 


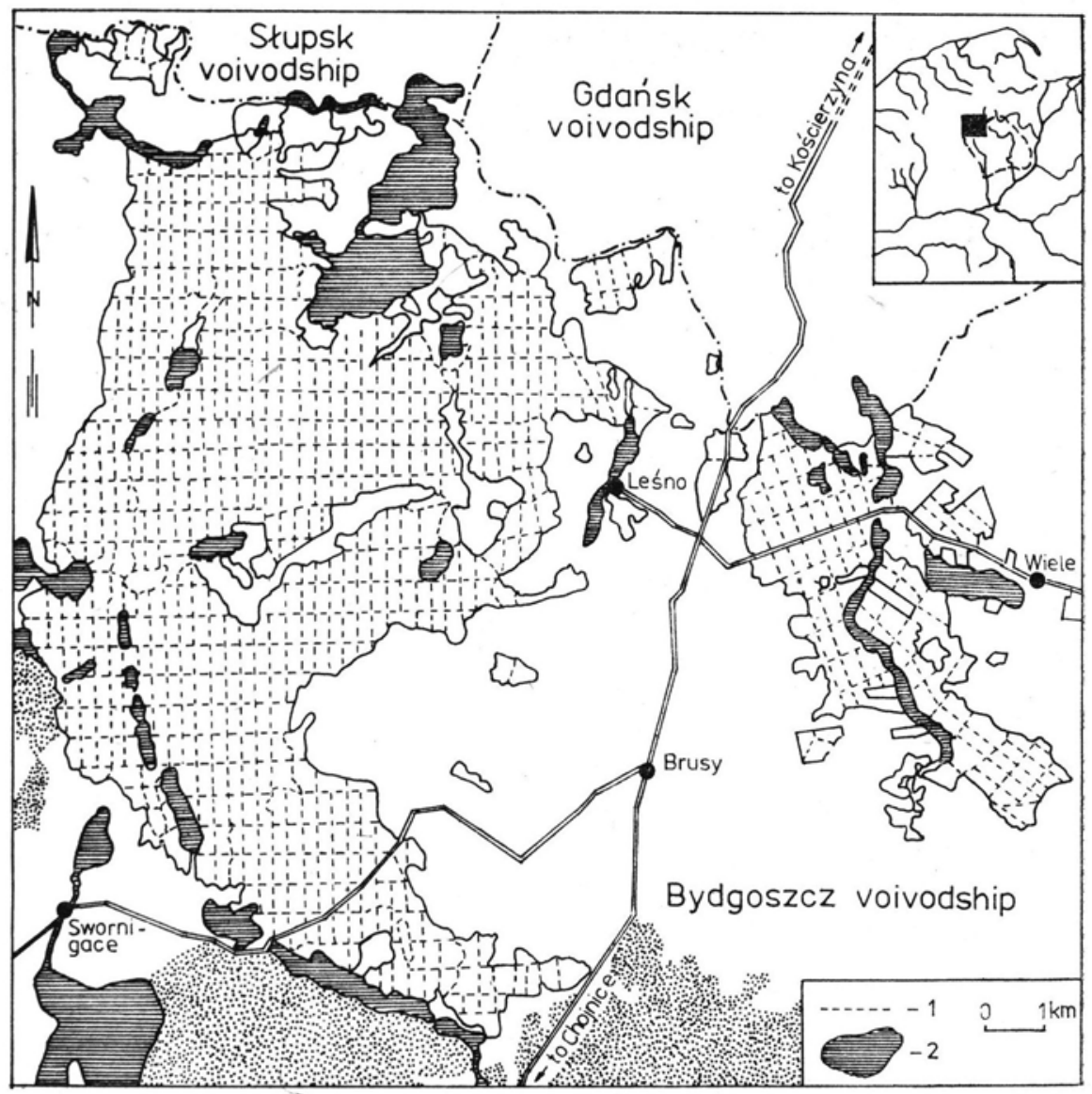

Fig. 1. Map of the studied area

1 - boundaries of the forest sections, $2-$ lakes

Ryc. 1. Mapa badanego terenu

1 - granice oddziałów leśnych, 2 - jeziora

the Bruska Upland. Lake hollows without any in- or outflow containing small lakes, transition or raised bogs are also numerous. Relative heights differ by no more than 20-30 m (G a lo n 1953) (Fig. 2).

The outwash plains in this part of Pomerania. were formed from fluvioglacial sands deposited here by the ice-sheet while it was stationary over the present Kashubian Lakeland area. Coarser, often gravelly sands were deposited in the studied area, which is adjacent to the line of terminal moraines. According to Prusinkiewicz (1973), the soils overlying these sands are slightly podsolized, although podsolization has proceeded further in the areas covered by forest. Prusinkiew i c z (1973) classifies most of the soils here as rusty soils or sand rankers. The former are to be found mainly under moist pine forest com- 


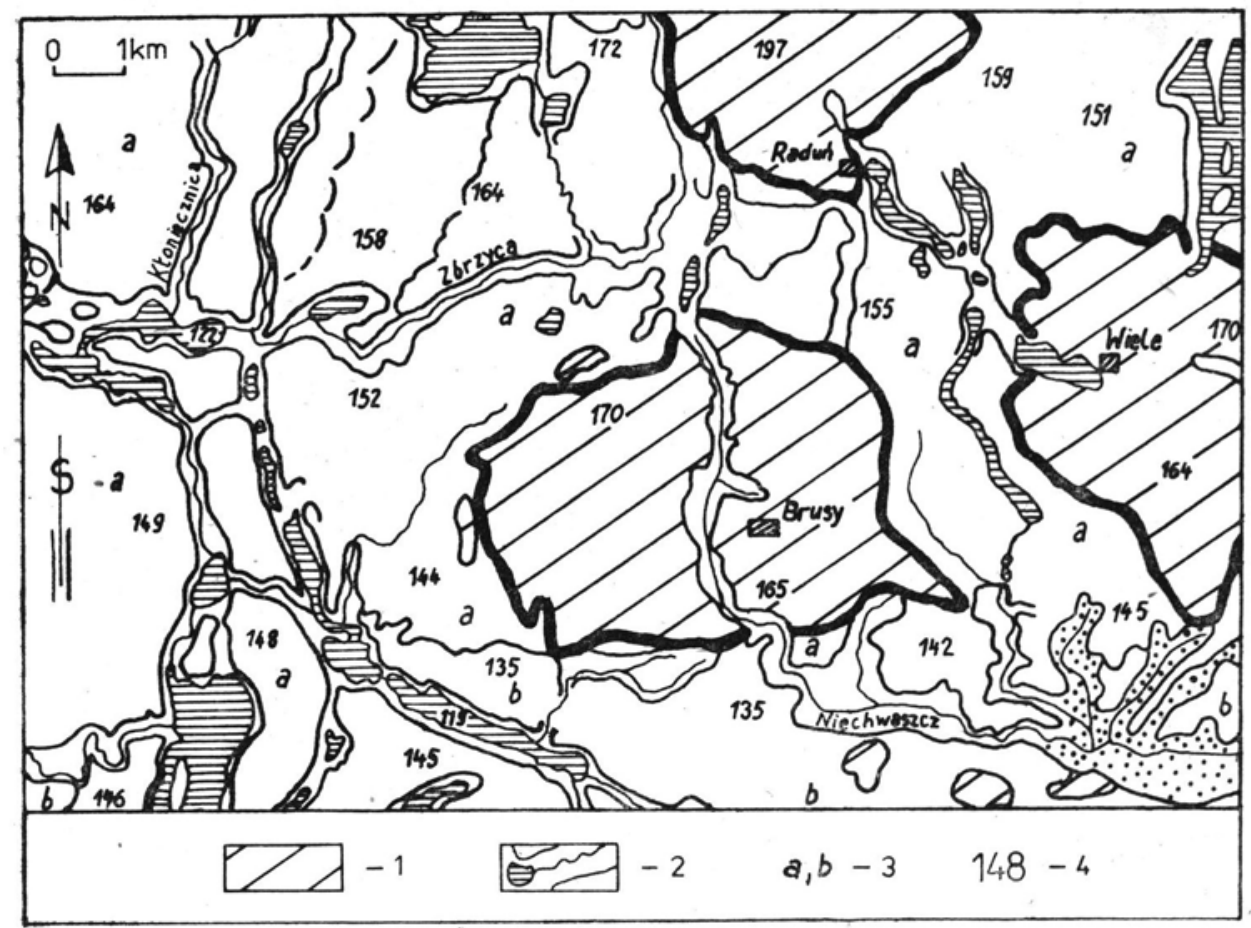

Fig. 2. Geomorphological map of the studied area (after Galon 1953, part) 1 - moraine upland, 2 - river valleys and lake channels, 3 - (a) older and (b) younger outwash plains, $4-$ absolute height above sea level

Ryc. 2. Mapa geomorfologiczna terenu badań (wg Galon a 1953, fragment)

1 - wysoczyzny morenowe, 2 - doliny rzeczne 1 rynny jeziorne, 3 - powierzchnie sandrowe starsze (a) i młodsze (b), 4 - wysokość bezwzględna (n.p.m.)

A

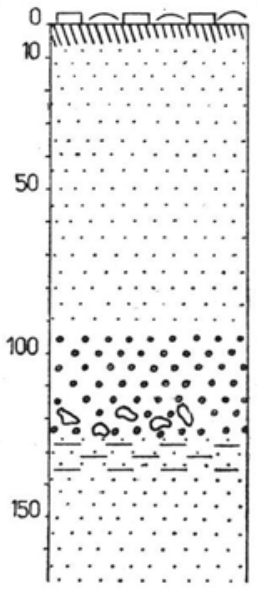

B

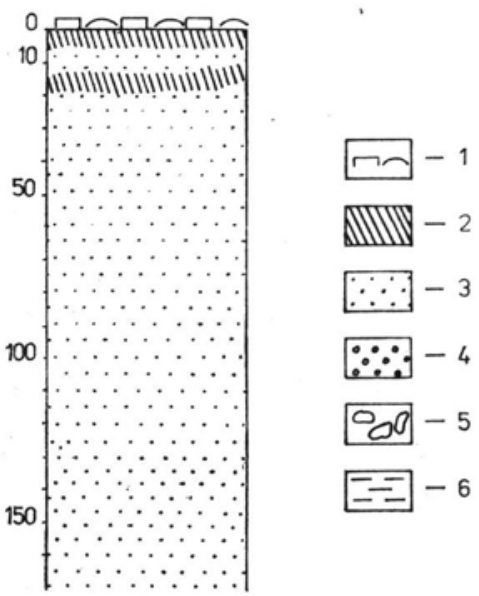

Fig. 3. Soil profiles of the Cladonio-Pinetum phytocenosis (scheme).

1 - litter, 2 - humus, 3 - loose sand, 4 - gravel, 5 - stones, 6 - brown inclusions

Ryc. 3. Profile glebowe $\mathrm{w}$ fitocenozach Cladonio-Pinetum (schemat)

1 - ściółka, 2 - próchnica, 3 - piasek luźny, 4 - żwir, 5 - kamienie, 6 - brunatne wkładki 
munities whereas the latter are characteristic of dry pine forest habitats.

Examples of soil profiles taken from the Cladonia-pine forest phytocenoses studied will be found in Fig. 3. Genetic horizons are weakly developed. The average $\mathrm{pH}$ of the contact area between the humus and mineral horizons is 4.8. In some forest subsections one finds a layer of tilth top-soil, showing that this land was cultivated in the past. Now, however, these soils are poor in nutrients and so are rarely used for agricultural purposes. Only on the moraine uplands (in the vicinity of Brusy, Wiele and Raduń) and in the river valleys where light clayey sands and low peats respectively are dominant (Prusinkiewicz 1973), have arable land or meadows taken over from forest.

\subsection{WATER REGIME AND CLIMATE}

Apart from precipitation, lakes and peat lands exert the greatest influence on the water regime in this area. There are a great number of lakes in the Przymuszewo F.I., the largest being Lakes Wielewskie, Skąpe, Młosino Duże, Leśno, Parzyn, Ḱruszyńskie, Milachowo, Gardliczno, Laska and Płęsno. The largest peat bogs include the Lake Stawek bog, and the peat bogs by Lake Zmarłe near Laska, by Lake Zmarłe near Wiele and by Lake Kły.

The forestry area is drained by the rivers Zbrzyca and its tributary, the Kulawa, and the Kłoniecznica, which flows into Lake Laska these rivers are part of the Brda catchment basin. Further drainage is effected by the river Niechwaszcz, a tributary of the Wda. All these rivers flow in valleys which have cut deeply into the outwash plains and the Bruska Upland (Fig. 2).

The Przymuszewo F.I. is situated on the boundaries of the Bytow and Człuchów climatic areas, within the lake district climatic regions
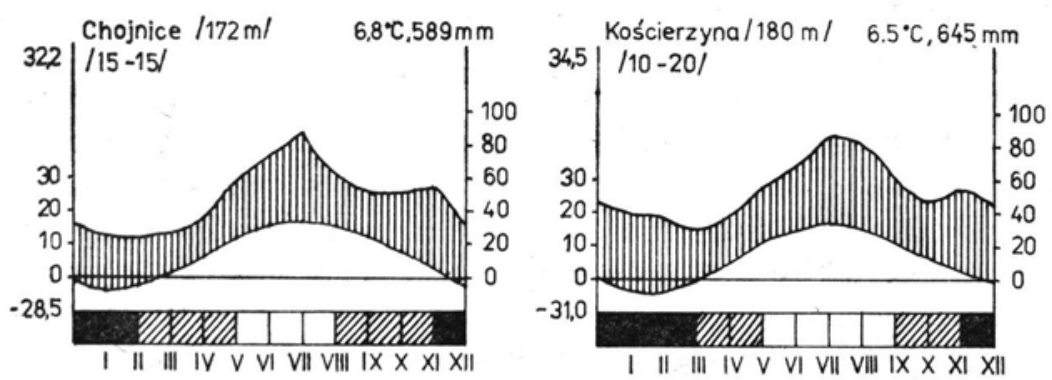

Fig. 4. Climatic diagrams for stations situated closest to the studied area, drawn according to the Gaussen-Walter metod (W a lter 1955)

Ryc. 4. Diagramy klimatyczne dla stacji położonych najbliżej badanego terenu, wykonane metodą Ga us en a-Waltera (Walter 1955) 
(R o m e r 1949). The chief climatic features of this area are shown diagramatically in Fig. 4 on the basis of data obtained from the nearest meteorological stations at Chojnice and Kościerzyna. The remaining data used in this chapter come from the same sources.

The mean annual rainfall is not high (Fig. 4) although in different years significant deviations from the mean have been recorded. For example, only $416 \mathrm{~mm}$ of rain fell in Chojnice in 1964, but as much as $829 \mathrm{~mm}$ in 1970; $412 \mathrm{~mm}$ fell in Kościerzyna in 1964, but $910 \mathrm{~mm}$ in 1967. On average, there are 225 days with rain per annum in Chojnice, and 170 in Kościerzyna. Snow lies on the ground for an average of 175 days during the year.

The climate of the north-western Bory Tucholskie is more continental than that of the neighbouring Kashubian Lake District (K wiecien 1979 ), and this is reflected by the vegetation (see chapter 3.3. and 6).

\subsection{VEGETATION}

The vascular flora of this area is relatively rich, despite the apparent monotony of the landscape and poverty of habitats. The author's own records and many others ( ski 1965; Lisowski et al. 1965, 1966a-1970; Ceynowa, Rejewski 1969; Boiński, Gugnacka-Fiedor 1977; Fałtynowicz 1978; Fałtynowicz, Szmeja 1978) indicate the presence of over 600 species of vascular plants in the Przymuszewo F.I. Many of them are rare or very rare in Poland. These include: Carex chordorrhiza, Lycopodium tristachyum, Cladium mariscus, Orchis ustulata, Isoëtes lacustris, Oxycoccus microcarpus, Liparis loeselii, Saxifraga hirculus, Lobelia dortmanna and Utricularia ochroleuca.

The Bory Tucholskie lie in the zone of contact between the suboceanic and subcontinental climatic types. This is demonstrated by, among others, the presence in this area of many subcontinental species, also of western range type. The interesting phenomenon of biotope change has been observed in many of these species as they move towards their range boundaries. Subcontinental species such as Anthericum ramosum, Arctostaphylos uva-ursi, Dianthus arenarius, Gypsophila fastigiata, Peucedanum oreoselinum, and among the lichens - Cetraria crispa and C. islandica, are found in this area exclusively on waysides, treeless slopes and heaths, and only very rarely in woodland interiors ( $\mathrm{F}$ a $1-$ t y n o w i c z 1978). On the other hand, east of the river Vistula, they are woodland plants characteristic or indicative of Peucedano-Pinetum (M at uszkiewicz, Matuszkiewicz 1973).

There are numerous peat-lands in the Przymuszewo F.I., especially transition bogs and raised bogs. In some of them rare vascular plants (see above) and bryophytes are to be found, e.g. Campthotecium nitens, 
Cinclidium stygium, Helodium lanatum, $\cdot$ Meesea triquetra, Paludella squarrosa, Scorpidium scorpioides, Sphagnum obtusum, Sph. papillosum, Sph. warnstorfii (Lis ow ski et. al 1965, 1966b, 1967b).

The large number of lakes in this area show great typological diversity, and have long since been of interest to botanists ( $\mathrm{E}$ a w ry nowicz 1964, 1965; Ceynowa, Rejewski 1969; Fałtynowicz, Szmeja 1978; Rejewski 1981). The so-called Lobelia-lakes are particulary worthy of notice as, apart from such species as Elisma natans, Isoëtes lacustris, Littorella uniflora, Lobelia dortmanna and Sparganium affine, interesting species and communities of algae have been found here (L uścińska 1979).

The most widespread woodland community in the studied area is Cladonio-Pinetum (see 6.1.). Large tracts, mostly along the rides, are poor, dry heathland (see 6.2.2.); but the Leucobryo-Pinetum association is also be found here (see 6.2.1). Vaccinio uliginosi-Pinetum (see 6.2.1.) grows on organic soils. Patches of this are never large, but they do occur on many of the peat-lands. Deciduous woodland communities such as Luzulo pilosae-Fagetum, Stellario-Alnetum, Circaeo-Alnetum, Galio silvatici-Carpinetum and Carici elongatae-Alnetum (Sokołow ski 1965) have been formed, often incompletely, on lakesides, river terraces and lake channel slopes. In comparison with pine forests, their numbers here are very small and still decreasing - most stands of Luzulo-Fagetum and Galio silvatici-Carpinetum have already been felled and pine planted in their place.

\section{THE NATURE AND GENERAL EFFECTS OF ANTHROPOPRESSURE}

\subsection{MAN'S INFLUENCE IN THE PAST}

From the Boreal period onwards, the chief constituent of woodlands on the extensive outwash plains to the south of the Pomeranian moraine belt was the Scotch pine (Pinus silvestris). Other tree species occurred as an admixture or else formed their own stands on the more fertile soils of the moraine uplands and river and lake channels (Tobolski 1975/1976). The pine is predominant in the Bory Tucholskie as a result of the more continental climatic conditions $(\mathrm{Czubinski}$ 1950 ) and the poor soil, to mention but two factors. Man has also contributed significantly to the enlargement of the area of pine stands.

The first traces of settlement in this area (near Swornigace) are from the end of the Paleolithic and Mesolithic Age (Boiński 1976). Settlement expanded during the Iron Age, and later, in the early Middle Ages ( $\mathrm{Slaski} 1951)$. At that time, the activities of the settlers did not go beyond the most fertile areas, that is, river valleys and lake channels. The 10th century A.D. may be taken as the time when the de- 
struction of the woodland vegetation began. It was then that settlement deep in the forests was initiated, and the total felling and plundering of timber, burning of woodland, swine and cattle grazing, removal of forest litter all intensified.

The area of Pomerania under forest decreased by about $3500 \mathrm{~km}^{2}$ from the 10 th to the 15 th centuries ( $\mathrm{Z}$ a b k o-Potopowicz 1954). Excessive tree-felling gradually reduced the fertility of the forest soils. Swine and cattle'grazing were also responsible for habitat impoverishment. According to information from archives, such grazing took place on a very large scale. For example, in the mid-17th century, flocks of sheep put out to graze in the forests near Brusy and Kosobudy often comprised up to 1500 animals. On abandoned fallow land and burnt areas self-seeding of heliophilous trees such as pine, birch and aspen took place. This led to soil degradation in those habitats from which oak, beech and hornbeam had been outsted.

Most harmful for the Bory Tucholskie was the intensive forest management introduced by the Prussians at the end of the 18th century, after the first partition of Poland. By planting all the cutting areas with the easily renewable and quick-growing pine, the tree stands of varying age and, in some places, of different species, were replaced by pine monocultures. Furthermore, pine was planted on disused land and sterile fields. It is true that this increased the woodland cover of this area to a considerable extent (Table 1), but it also increased the number of lower-grade tree stands.

Table 1 - Tabela 1

The tree cover of the former district of Chojnice ${ }^{1}$

Lesistość byłego powiatu chojnickiego ${ }^{1}$

\begin{tabular}{|c|c|c|c|c|c|}
\hline $\begin{array}{c}\text { Years } \\
\text { Lata }\end{array}$ & 1913 & 1921 & 1937 & 1960 & 1975 \\
\cline { 1 - 2 } $\begin{array}{c}\text { Tree cover (in \%) } \\
\text { Lesistość (w \%) }\end{array}$ & 33.6 & 34.5 & 40.2 & $42.8^{2}$ & 49.0 \\
\hline
\end{tabular}

1 Data from Przymuszewo F.I.; dane $\mathrm{z}$ nadleśnictwa Przymuszewo. 2 After S. B a c and S. Ostrowski (1969); według S. B a c a i S. Ostrow$\mathrm{s}$ k i e g o (1969).

The introduction of pine monocultures on to such poor habitats made the stands more susceptible to disease and pests. As a result of great invasions of insects (Panolis flammea Schiff. in 1924; Diprion spp., Lymantria monacha L. and Panolis flammea at the present time), many thousand of hectares of woodland have been destroyed (Koehler 1971; Fudała 1980). This, and frequent felling are the reasons for the relative newness of the stands; in the Przymuszewo F.I. woods with 


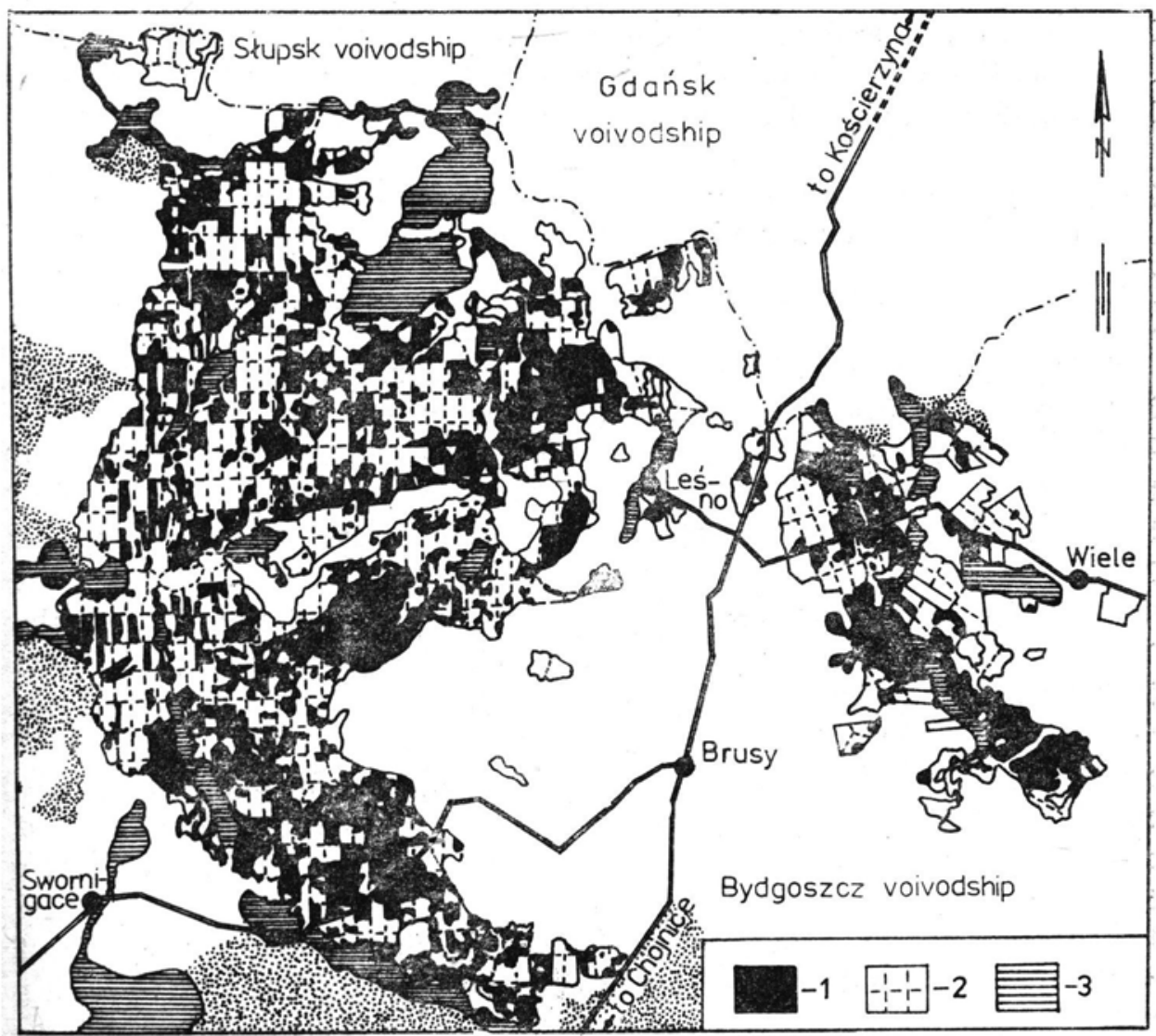

Fig. 5. Tree stands with 50-year old pines and older in the Przymuszewo F.I. (state for 1976)

1 - stands with pines over 50-year old, 2 - boundaries of the forest sections, 3 - lakes Ryc. 5. Drzewostany z sosną 50-letnią i starszą w nadleśnictwie Przymuszewo (stan na 1976 rok)

1 - drzewostany z sosną mającą powyżej 50 lat, 2 - granice oddziałów leśnych, 3 - jeziora

50 -year old and older pines make up less than half of the total woodland (Fig. 5). It is exceptional to find stands over 100-year old.

Man's activities over many years have brought about great changes in the pine-forest phytocenoses although, as regards the appearance of species which are geographically and habitat-foreign, synanthropization here has been minimal. Because of the extreme soil and water conditions, the pine forest communities, especially the dry pine forest, are relatively closed systems. Thus the number of synanthropic species here is much smaller than on more varied and richer land. These plants are to be found only alongside forest paths, in cutting areas and on tilled land within the forests. Only now that in recent years undergrowths 
have been introduced and boskets of deciduous shrubs planted on a wider scale has the penetration and domination of the pine-wood phytocenoses by habitat-foreign species become more likely (see 7.3.1.).

\subsection{PRESENT-DAY METHODS OF FOREST MANAGEMENT AND THEIR SIGNIFICANCE IN HABITAT FORMATION}

\subsubsection{TRADITIONAL CULTIVATION METHODS}

Forest management includes a number of procedures, each of which has a profound influence on the forest ecosystem. These include treefelling, planting, tending of plantations, boskets and tree-stands. All these operations are to create "tree-stands which are top-grade from both the biological and production points of view" (Leibundgut 1972; T r a m ple r 1979).

The most frequent mode of felling in Poland, and thus also in the forests studied here, is clear-cutting of standardized sections of forest $60-80$-metre wide and up to 6 ha in area. Less often, narrower areas of up to 4 ha and $40-60 \mathrm{~m}$ in width are clear-cut. At present, $80 \%$ of forests in Poland are managed by clear-cutting. In pine forest habitats, timber is obtained in this way only. Clear-cutting is the cause of much controversy among foresters (see $\mathrm{Fischer} 1978$; K reutzer 1979 , and others). It is used mainly because of the ease of planting (especially pine) and the possibilities of applying intensive methods of cultivation and land reclamation (I l m użyński 1969; Trampler 1979).

Clear-felling is an ecological disaster for the biological system within the affected area. An entirely new biocenosis comes into existence with a different microclimate, soil structure, flora and fauna.

Clear-felling over a large area brings about a change in the local climate which from all aspects differs significantly from that which exists in the forest (Sokołowski 1961, 1970b; Włoczewski 1968; Puchalski, Prusinkiewicz 1975, and others). According to Sokołowski (1961), the greatest differences between the forest and the felled area are found in the ground layer of air (up to $5 \mathrm{~cm}$ ), which is of tremendous importance to pine saplings, vascular plants, bryophytes, lichens and small animals. In the felled area," average maximum temperatures are $6-9^{\circ} \mathrm{C}$ higher and minimal several degrees lower than in the forest. Diurnal temperature amplitudes increase. Ever greater differences are to be found in the soil temperature - in the felled area at a depth of $5 \mathrm{~cm}$ it is $10-15^{\circ} \mathrm{C}$ higher than in the forest. The higher temperatures are responsible for a much greater deficiency of humidity in the air. Evaporation in the soil also increase: in summer it is 9 times greater than in the shelter of trees. After felling, the wind velocity increases over the exposed area. Some compensation for the 
worse conditions of humidity is the greater precipitation. $100 \%$ of the precipitation reaches the soil in a felled area, whereas in a pine forest of age class IV this value decreases to $38 \%$ according to Krečmer and Fojt (quoted by $\mathrm{Obminski} 1970$ ), but to $76 \%$ according to $\mathrm{Toma-}$ n e k (1955).

After felling a dry pine forest habitat, the ground water level may rise somewhat, as happens in a moist pine forest (Kosturkiew-ic z 1964). This, however, is of no importance to the plants as its roots cannot in any case reach the water.

The use of heavy equipment for removing logs and clearing the felled area, and later, for ploughing furrows for young pine plants adversely affects the soil structure and mixes its upper layers (G latzel 1979; Kreutzer 1979). For a short time the soil acidity decreases while mineralization accelerates. The surface of the soil dries out (W ł oczewski 1968; Puchalski, Prusinkiewicz 1975). The soil fauna undergoes enormous changes: forest species cease to exist there for up to twenty years and are replaced by eurytopic and thermophilous forms ( $\mathrm{S} \mathrm{z} \mathrm{u} \mathrm{jecki} \mathrm{1976).} \mathrm{The} \mathrm{regeneration} \mathrm{of} \mathrm{the} \mathrm{forest} \mathrm{soil} \mathrm{entomo-}$ fauna takes about twenty years.

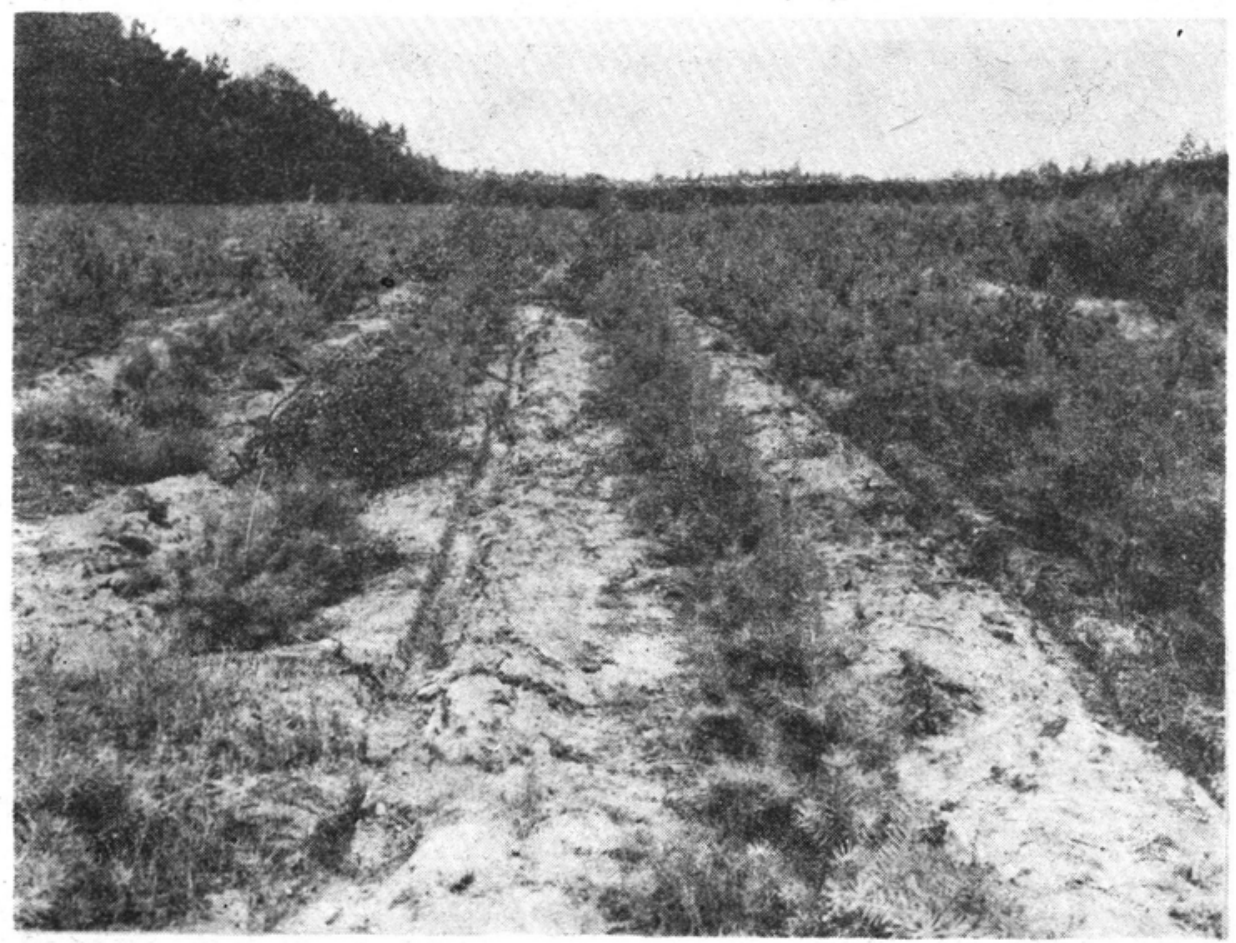

Fig. 6. 6-year old pine plantation with ploughed furrows (Photo J. Herbich)

Ryc. 6. 6-letnia uprawa sosnowa z wyoranymi bruzdami (fot. J. Herbich) 

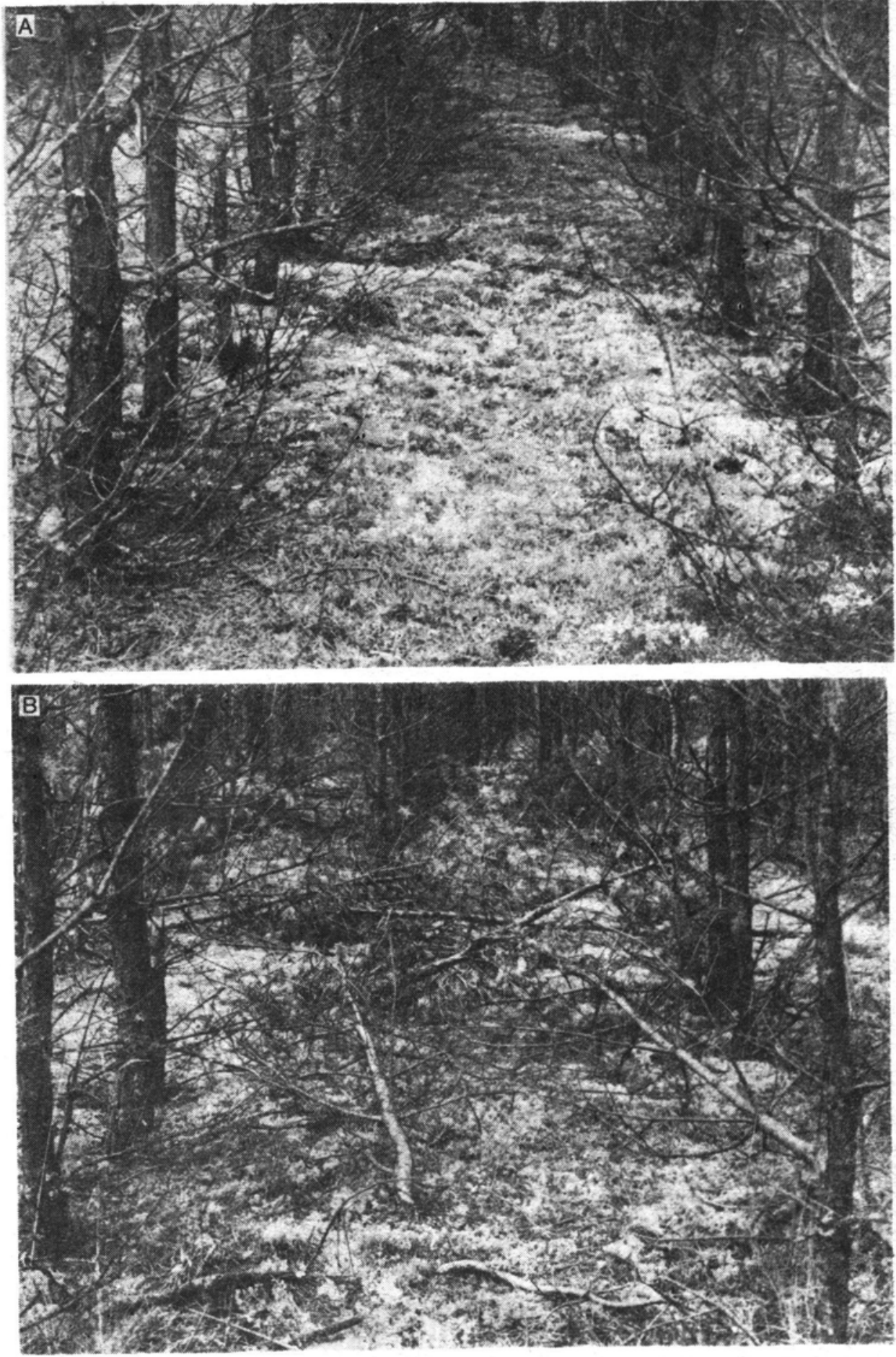

Fig. 7. Pine bosket before (A) and after (B) thinning (Photo J. Herbich) Ryc. 7. Młodnik sosnowy przed (A) i po (B) czyszczeniu (fot. J. Herbich) 
As compared with the original woodland, the species composition of small mammals also changes after felling ( $\mathrm{Grodzinski} 1958$ ).

Furthermore, radical changes take place in the flora after felling (see e.g. Sokołowski 1961, 1970b, 1972; Fijałkowski 1971; M a rkowski 1971, 1974, 1982). In the studied area, forest species have all but disappeared from the dry pine-forest habitat. They have been replaced by eutrophic and heliophilous species characteristic of sward associations from the class Sedo-Scleranthetea, heathland and the dry margins of coniferous woodland. Where larger quantities of decaying humus have accumulated, one may find nitrophilous plants such as Senecio silvaticus (see 7.2.1.). The undergrowth of a felled forest perishes as a result of the rapid change in habitat conditions; it is also destroyed mechanically during felling and clearing (Sosnowski 1977) and while preparing the surface for reafforestation. The destruction of the surface layer of soil and the undergrowth in a dry pine-forest is as a rule so great that both soil regeneration and secondary succession start practically from scratch.

A pine plantation is started in the same year as felling or one year later. The young trees are planted in furrows at intervals of $1.2 \mathrm{~m}$ (1417 thousand trees per hectare). While tending the plantation, the ridges between the furrows should be ploughed up at least once (Fig. 6). This causes significant alternations in the floristic content - the quantitative relationship between the components of the initial stages of the secondary succession is broken up.

At the plantation stage the young pines are very small, their branches do not interlace and their effect on the habitat is minimal. Even in 10-year old plantations most of the sunlight reaches the soil (W 1 oczewski 1968). After having grown above the ground cover and formed a canopy of bosket, the trees influence the environment to a much greater extent. The ground cover is now in shade; this is reflected by its floristic composition (see 7.1.). The boskets are thinned every three to five years (Figs. 7A, B). The next stages of development are thickets - trees with a d.b.h. of up to $20 \mathrm{~cm}$. Now the pines begin to grow more rapidly, weaker individuals die off, and branches fall from the lower parts of the trunk. Stands which have attained the thicket stage exert a considerable influence on the microclimate, soil and undergrowth; as a rule the density exceeds $75 \%$. Hardly any sunlight penetrates directly to the forest floor, and the average intensity of dispersed light is about $40 \%$ of that in an open space (O b m in ski 1970). In comparison with plantations, boskets and older stands, the humidity of air and soil has reached its maximum value. At the same time however, the nutrient deficiency has become acute since the quickly growing pines require large quantities of mineral salts. After the selective thinning (Fig. 8) which is normally done at this stage (I l m u- 
żyński 1969; Leibundgut 1972; Obmiński 1977), another significant change in the habitat conditions follows. The tree-canopy is less dense with the result that the floor of the forest is now better illuminated. The temperature relationships change here, e.g. the soil temperature in summer is higher and in winter lower than in unthinned stands. The soil humidity alters as well (Puchalski, Prusin$\mathrm{ki}$ ewicz 1975). After thinning a dry pine forest habitat, there remain about 600 to 800 trees per hectare.

Maturing and mature tree-stands (age classes III and IV) represent a typical Cladonia-pine phytocenosis.

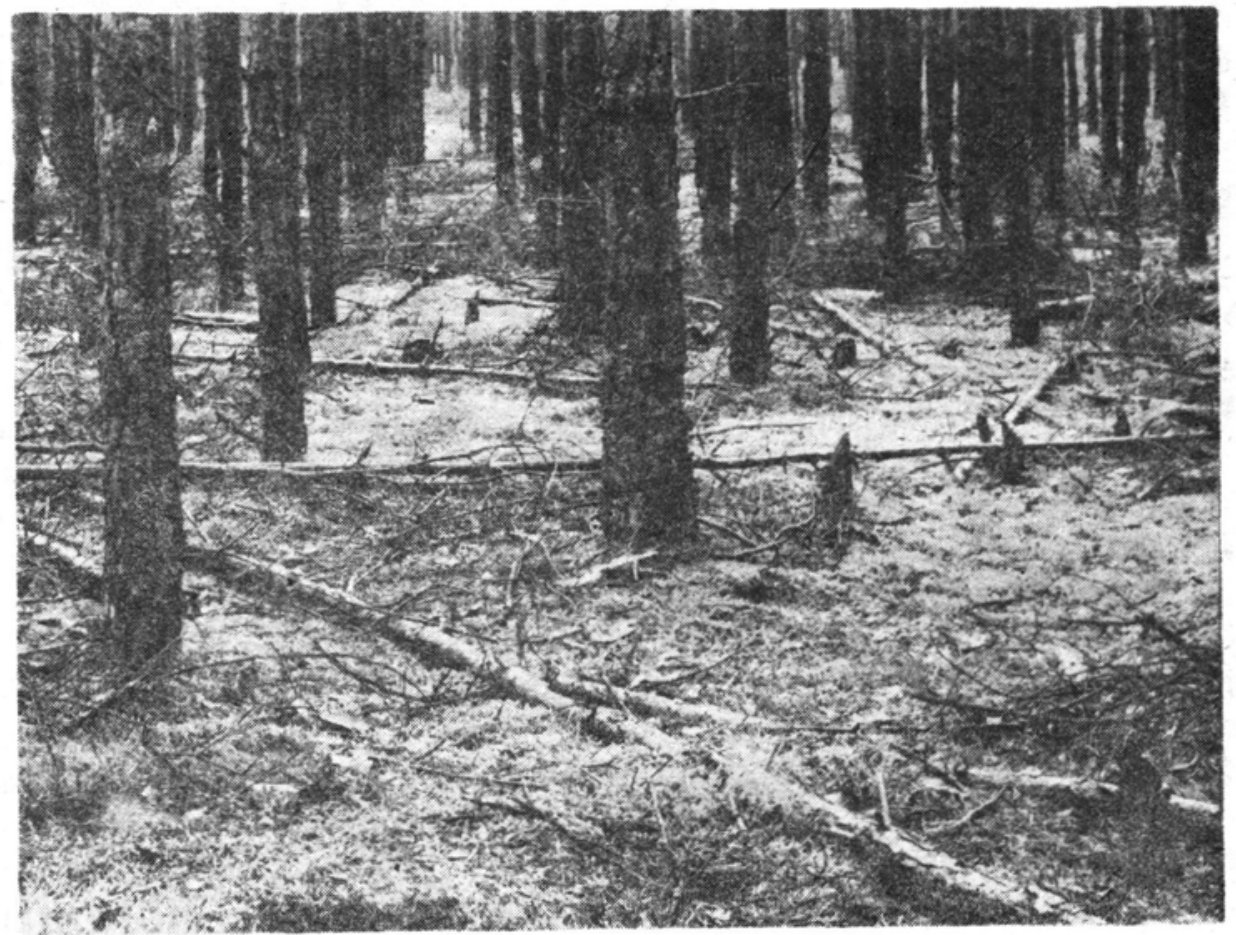

Fig. 8. Pine stand after thinning (Photo J. Herbich)

Ryc. 8. Drzewostan sosnowy po trzebieży (fot. J. Herbich)

\subsubsection{HYLOMELIORATION}

The production potential of a dry pine forest is very low. In order to increase it, various methods which may be grouped under the general heading of hylomelioration are used. This term implies procedures whose aim is to improve the habitat conditions, especially: "- the improvement of the soil in forests and non-forest areas which are to be renewed or afforestated [...], in particular, the enrichment of the soil with nutrients and the intensification of its biological activity; the increase in production capacity of soils on arable land and in older 
tree stands where growth and development have become retarded" (Krzyszkow ski 1974).

In the study area, the hylomelioration procedures mainly applied are mineral fertilization and the seeding of underbrush.

At present, mineral fertilization is in many countries one of the basic procedures used to raise soil productivity (cf. Holmen 1978; R ydin 1978). Foresters are of the opinion that this procedure should be more widely applied for the following reasons:

- there is little likelihood of an increase in the area covered by woodland;

- the constantly rising demand for timber;

- the large number of forests on pooi and degraded soils (over 1 million ha in Poland (Krzyszkow ski 1974) of which nearly $70 \%$ is dry pine forest ( $\mathrm{Z}$ a $\mathrm{r}$ ę b a 1976));

- the worsening of the already considerable nutrient deficit in most forest soils by the removal of large quantities of organic matter in the form of wood. According to Kreutzer (1979), the quantities of nutrient elements in pine stands as a result of felling decrease as follows (kg/ha): N $-430-800, \mathrm{P}-50-80, \mathrm{~K}-260-420, \mathrm{Ca}-290-480, \mathrm{Mg}-$ 50-105.

From the economic standpoint, mineral fertilization appears to be justified on degraded and very poor habitats. It gives a fairly good increase in tree growth, provided the procedure is repeated many times on the same area ( $\mathrm{Zimny} \mathrm{1966;} \mathrm{B} \mathrm{a} \mathrm{u} \mathrm{le,} \mathrm{Fricker} \mathrm{1973;} \mathrm{G} \mathrm{a} \mathrm{lo} \mathrm{ux}$ 1979). In addition, fertilization makes the pines more resistant to low temperatures, industrial pollutants, insect pests and parasitic fungi (K ow a lk ow ski 1979).

The studies carried out so far on the effect of mineral fertilization in forests are very one-sided. Their authors were primarily interested in the trees. Now mineral fertilization gives rise to a whole range of interactions in forest biocenoses, affecting not only the vegetation but the animals, microorganisms and soil as well. The direct and indirect results of fertilization have not yet been fully and reliably assessed, so such drastic interference in forest ecosystems must understandably arouse many fears and suspicions. The lack of scientific control has led to much neglect in forest management and to errors whose extent and effects are at present impossible to assess fully and which may take several ten of years to reveal themselves entirely (cf. O l a c z e k 1972; O bmiński 1977). Even so, despite our insufficient knowledge of how mineral fertilizers affect woodland communities, the consumption of fertilizers in forestry and the areas fertilized are continually rising ( $\mathrm{K}$ ajak, Prończuk 1979).

Large-scale mineral fertilization was usual in the north-western Bory 
Tucholskie. Its influence on the vegetation of Cladonia-pine forest is described in detail in 7.2.

The other hylomelioration procedure which has found favour in the forests studied, but whose effects are nowhere nearly as farreaching as those of fertilization, is the seeding of underbrush. Various species of trees and deciduous shrubs, more rarely spruce, are used for this purpose. Certain aspects of the introduction of such plants into the Cladonio-Rinetum habitat are discussed in greater detail in 7.3.1.

\section{CHARACTERISTICS OF THE LICHEN FLORA}

\subsection{THE DISTRIBUTION OF SPECIES}

In the north-western Bory Tucholskie 157 lichen species and 74 lower taxa have been found. A list of these species was included in a separate paper (F a 1 t y n ow i c z 1980). The largest number of species are from the genera: Cladonia (34), Lecanora (18), Lecidea (9), Pertusaria and Usnea (8 each), Bryopogon and Cetraria (7 each) and Parmelia (6). Twothirds of all the taxons are from these genera. Worthy of note is the large number of Bryopogon and Usnea species, also the widespread distribution and abundance of many of them. This is exceptional in Poland and proves inter alia that the air in this part of Pomerania is very clean.

Out of the total of 157 taxons, 30 are very rare, i.e. occurring in only one locality. These are very interesting lichens, rare on the lowland or in the whole of Poland, and include Bryopogon implexus, B. tatarkiewiczii, Calicium abietinum, Cyphelium caliciforme, Sterocaulon paschale, Umbilicaria deusta, Usnea glauca, U. laricina, U. perplectans, U. wasmuthii; also species rare only in the studied area, e.g. Calcium viride, Caloplaca murorum, Cladonia foliacea, Cl. grayi, Parmelia pulla. Cetraria nivalis was also found in one locality. This is one of two such localities of this arctic-alpine lichen in lowland Poland and the sixth in lowland Central Europe (F a łtynowicz, Tobolewski 1980; F a ł ty nowicz, Budzbon 1982).

40 species are rare (2-5 localities) and 47 are quite frequent (6-15 localities). 23 species are frequently found in the studied area (16-25 localities), while 17 common species were found in over 25 localities. The latter are exclusively lichens connected with various stages of succession in the Cladonio-Pinetum habitat, and pine and birch epiphytes: Cetraria sepincola, Cladonia chlorophaea, Cl. bacillaris, Cl. cornuta, Cl. gracilis, Cl. mitis, Cl. rangiferina, Cl. sylvatica, Cl. uncialis, Hypogymnia physodes, Lecanora conizaea, Lecidea granulosa, L. scalaris, Lepraria aeruginosa, Parmeliopsis ambigua, Pseudevernia furfuracea and Cornicularia aculeata.

The number of lichens found in the Przymuszewo F.I. is approxi- 
Table 2 - Tabela 2

A comparison of the lichen flora of three forest complexes in lowland Poland

Porównanie flor porostów trzech kompleksów leśnych Polski niżowej

\begin{tabular}{|l|r|r|r|}
\hline & \multicolumn{3}{|c|}{$\begin{array}{c}\text { Number of species } \\
\end{array}$} \\
\cline { 2 - 4 } & 1 & 2 & 3 \\
\hline Cladoniaceae & 37 & 34 & 37 \\
Parmeliaceae & 19 & 18 & 19 \\
Usneaceae & 20 & 9 & 16 \\
Lecanoraceae & 18 & 20 & 12 \\
Lecideaceae & 12 & 14 & 11 \\
Pertusariaceae & 9 & 13 & 7 \\
Physciaceae & 10 & 8 & 9 \\
Caliciaceae & 7 & 9 & 2 \\
Other families & 25 & 29 & 33 \\
Inne rodziny & & & \\
\hline Total & 157 & 154 & 146 \\
Ogólem & & & \\
\hline
\end{tabular}

1 - Przymuszewo F. I.; nadleśnictwo Przymu5zewo. 2 - Smolarz F. I. (I z y d or e k 1978); nadleśnictwo Smolarz (I z y d or e k 1978). 3 - Kampinos Forest (Z i e líńs k a 1967); Puszcza Kampinoska (Z i elíńs k a 1967).

mately the same as that found in lowland areas with similar vegetation such as the Kampinos Forest (Puszcza Kampinoska) (Zielinska 1967) and the Smolarz F.I. in the voivodship of Gorzów Wlkp. (I z ydorek 1978) (Table 2). These three areas have many species in common, the number of the particular taxonomic groups is also similar.

\subsection{HABITAT GROUPS}

In the flora studied, epiphytes are most numerous with 103 species, 56 of which grew only on tree bark. 58 taxons were found on decaying wood, 5 of them were exclusive to this habitat (Calicium abietinum, Cladonia botrytes, Cyphelium caliciforme, Lecanora varia and Lepraria candelaris). 51 species occurred on the ground, and 18 of these were not found elsewhere. Only 30 epilithic lichen species were found, and most of them (20) grew exclusively on a rocky substrate.

\subsubsection{TERRICOLOUS LICHENS}

In the studied area, terricolous lichens are the most widespread and important as regards the structure of higher plant phytocenoses. Cladonia species predominate, mainly $\mathrm{Cl}$. chlorophaea, Cl. furcata, Cl. gracilis, 
Cl. mitis, Cl. rangiferina, Cl. sylvatica and Cl. uncialis. Apart from these, Lecidea granulosa, L. humosa, L. uliginosa, Cladonia bacillaris, Cl. cornuta and $\mathrm{Cl}$. deformis are abundant, especially in young pine plantations and in the initial stages of sward and heathland. The rarer but none the less interesting species of terricolous lichens include the above-mentioned Cetraria nivalis, and also Cladonia alpestris, Cl. scabriuscula, Pycnothelia papillaria and Stereocaulon paschale. The influence of ground lichens in the most important plant communities of the studied area are discussed in greater detail in chapters 6 and 7 .

\subsubsection{EPIPHYTIC LICHENS AND DECAYING WOOD}

60 species of lichens grow on Betula verrucosa; no other tree speeies in the study has such an abundant epiphytic flora. Somewhat fewer taxons were found on Salix spp. (44) and Populus spp. (41). Acer platanoides and Pinus silvestris also have a fairly rich lichen flora (35 species each). Far poorer are Alnus glutinosa with 24 species, Fagus silvatica with 21, Quercus spp. with 18 and Juniperus communis with 10.

The predominant tree species in the studied area is Pinus silvestris. Pine epiphytes are discussed in depth in 7.1.2.

Betula verrucosa grows mainly along woodland paths, on rides, fireprevention strips, and on the fringes of lakes and peat-bogs; it is less frequently found as an admixture in pine stands. The commonest species growing on birch bark are Hypogymnia physodes, Cetraria chlorophylla, C. glauca, Pseudevernia furfuracea, Bryopogon crispus and Lecidea scalaris. Heavy branches are usually covered with large quantities of Lecanora conizaea and numerous brown thalli of Cetraria sepincola. Lichens of the Usneaceae family are frequent and numerous on birch bark. Humus accumulates in the deep bark fissures of old birches and Cladonia species may be found here.

Of the plants with woody shoots which grow in a dry pine forest, Juniperus communis, Calluna vulgaris, Vaccinium myrtillus, V. vitisidaea and the rarer Arctostaphylos uva-ursi and Empetrum nigrum were also included in the study. None of these shrubs have much in the way of epiphytic flora. Lecanora conizaea, and more rarely Hypogymnia physodes and Lepraria aeruginosa, are numerous and sometimes found in very large quantities on junipers and old heather. The first two of the above-mentioned species were found very rarely and then singly on Arctostaphylos uva-ursi, Empetrum nigrum and Vaccinium spp.

Willows, mainly Salix alba and S. fragilis, and poplars, Populus nigra and $P$. tremula, growing singly on lake and river banks and on forest fringes have a rich and varied epiphytic flora. Lecanora, Parmelia, Physcia s.l. and Xanthoria species are most often found here. Acer platanoides is similar to the willows as regards epiphyte composition. 
One tree frequently found along streams, the banks of lakes and the edges of peat-lands is Alnus glutinosa. Not many lichens grow on it, but those that do occur most often include Hypogymnia physodes, Lecanora conizaea, Phlyctis argena, Parmelia sulcata and P. fuliginosa.

Other tree species are rare in the studied area and do not constitute an important habitat for lichens.

The lichen flora of decaying wood is extremely rich, Cladonia spp. being predominant among them. A detailed discussion of the flora and succession on rotting pine stumps will be found in chapter 7.1.3.

On the decaying stumps of deciduous trees, such as birch and beech, which are fairly rare in the studied area, Cetraria chlorophylla, Cladonia coniocraea, $\mathrm{Cl}$. chlorophaea, Coniocybe furfuracea and Hypogymnia physodes are quite numerous.

The most interesting lichen species found on rotting wood are Calicium abietinum and Cyphelium caliciforme.

\subsubsection{EPILITHIC LICHENS}

Epilithic lichens make up the smallest group with only 30 species. This is because there are very few suitable habitats. A natural habitat for epilithic lichens in a dry pine forest are small sandstone pebbles found mostly on rides. These stones are usually covered with Lecidea crustulata and Trapelia coarctata, less frequently with Lecidea soredizodes and Rhizocarpon obscuratum. Parmelia conspersa and P. pulla were found on a few larger boulders.

Particulary worthy of note is the locality of Umbilicaria deusta, a montane lichen rarely occurring on the lowland (F a l ty nowicz 1981), which was found on a small stone at the edge of a pine bosket.

Concrete ride posts are an anthropogenic habitat whose lichen flora in comparison with that of the sandstone pebbles is entirely different. Nitrophilous species are frequent and numerous here and include Candelariella aurella, Phaeophyscia nigricans, Physcia adscendens and $\mathrm{Ph}$. tenella, more rarely Xanthoria parietina and Acarospora fuscata. Caloplaca decipiens and Lecanora dispersa occur in masses on the walls and tiles of buildings.

\section{COMMUNITIES CONTAINING LICHENS}

\subsection{CLADONIO-PINETUM (TABLE 3)}

In the north-western Bory Tucholskie Cladonia-pine forest covers an area far greater than that of the remaining woodland communities. It is to be found on very poor, dry soils, on flat out-wash plains and on south- and south-west-facing sandy slopes.

The stands consist exclusively of pines of yield class IV (exceptional- 
ly III or V). The trees are low,' the average height at 70 years being $14 \mathrm{~m}$, and their trunks are often deformed. The density is low, about $60 \%$ on average. There is normally no underbrush; young pines and singel junipers of much reduced vitality occur sporadically. Small shrubs and herbaceous plants are of little importance only in places does one find Calluna vulgaris and Deschampsia flexuosa in rather greater number. The lichen-moss layer is dominated by grey concentrations of lichens interspersed with green patches of mosses, giving the community a singular appearance (Fig. 9).

Cladonio-Pinetum phytocenoses are-floristically poor - lichen and bryophytes predominate. Of the average of 18 species noted in one record, 15 were cryptogamic. Six species are widespread: Cladonia sylvatica, Cl. rangiferina, Cl. gracilis, Cl. uncialis, Pleurozium schreberi and Dicranum polysetum.

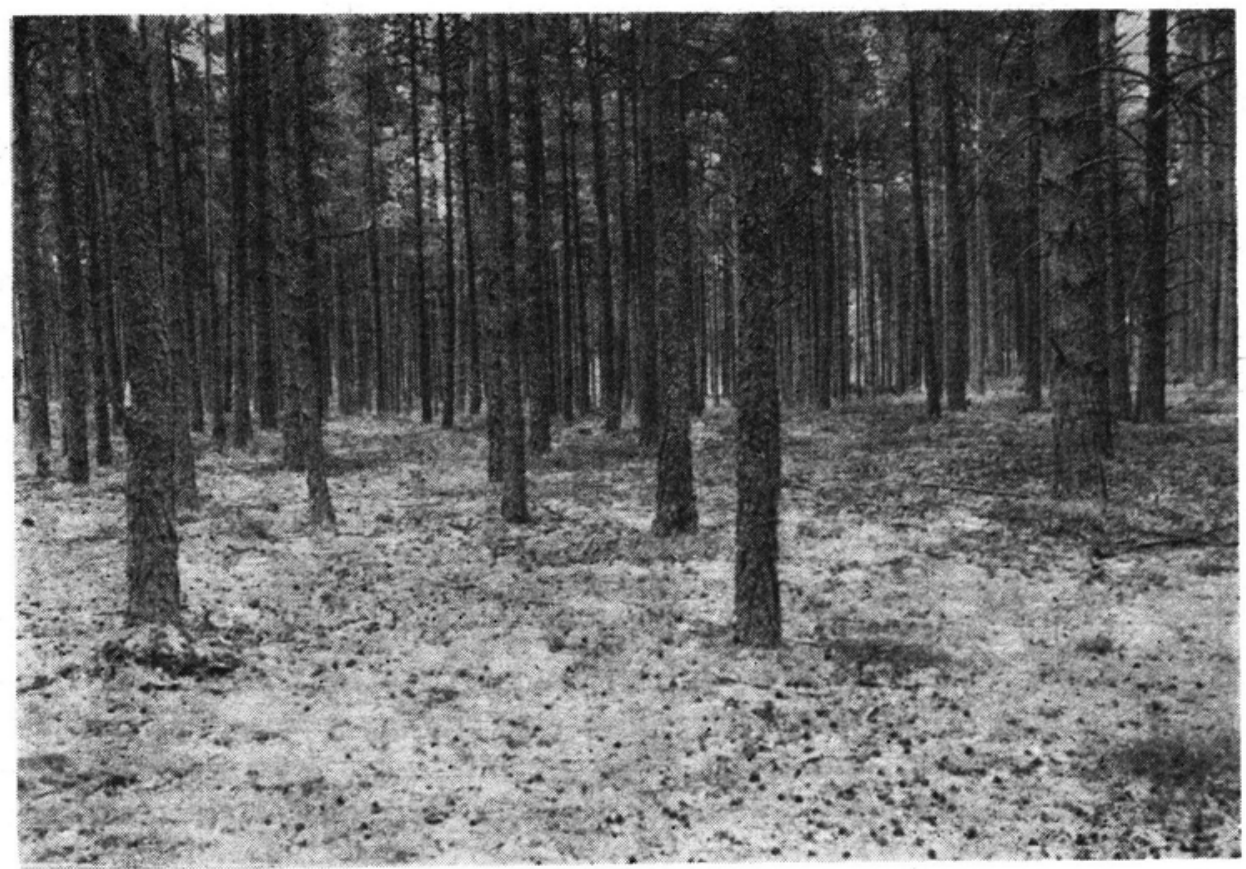

Fig. 9. Cladonia-pine wood (Photo J. Herbich)

Ryc. 9. Bór chrobotkowy (fot. J. Herbich)

In the phytocenoses studied, the suboceanic bryophytes Ptilidium ciliare and Dicranum spurium and the lichens Cladonia impexa and Cornicularia aculeata are found with great constancy. This means that this community can be included in the suboceanic variant of Cladonio-Pinetum (western variant according to Sok ołow ski 1970a) distinguished by Matuszkiewicz and Matuszkiewicz (1973).

The Cladonia-pine forest in the studied area exists in two variants: 
Table 3 - Tabela 3

Cladonio-Pinotum Juraszek 1927

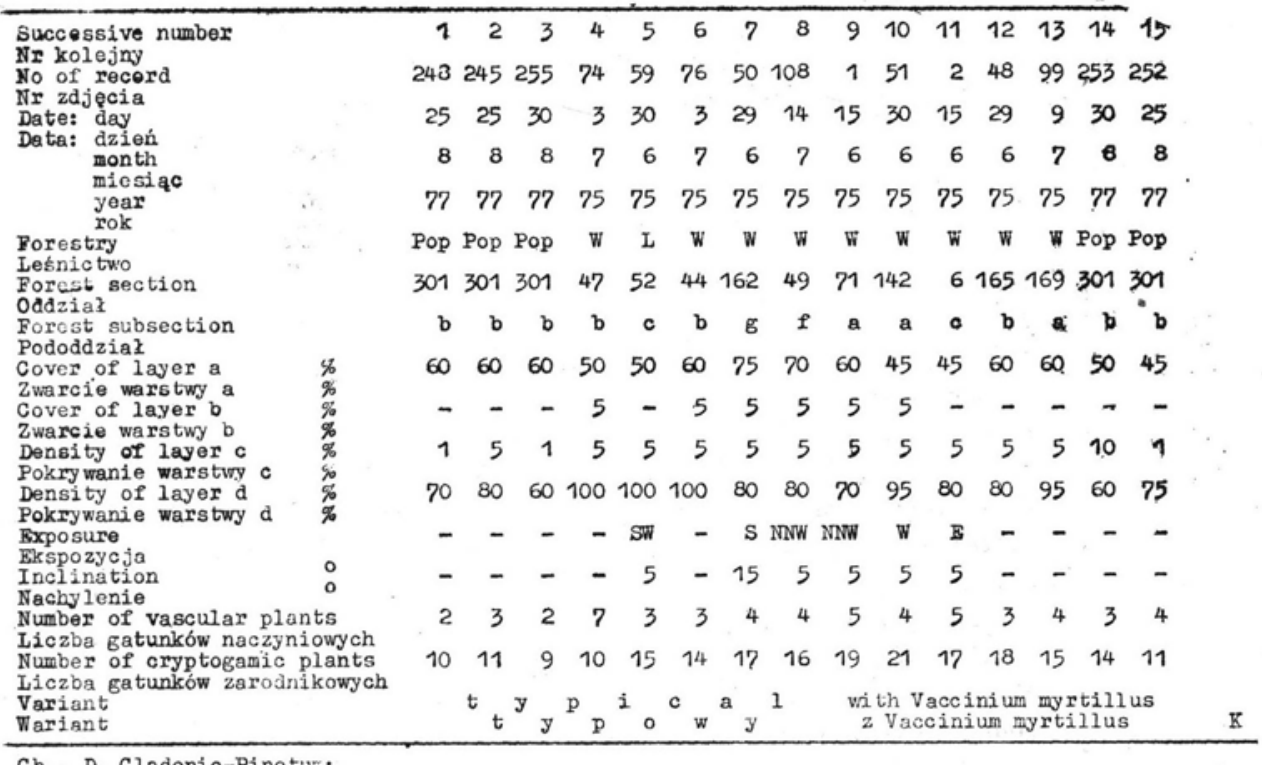

Ch., D. Cladonio-Pinetus:

Cladonia sylvatica

$\begin{array}{ll}\text { " } & \text { rangiferina } \\ \text { " } & \text { deformis } \\ " & \text { degenerans } \\ " & \text { squamosa } \\ " & \text { tenuis } \\ \text { " } & \text { furcata }\end{array}$

D. suboceanic variant:

D. wariantu suboceanic iuego:

v'tilidium cillare

Corricularía aculeata

Cladonia impexa

Dicranur sptirium

Ch. Vaccinio-Piceevea:

Finus silvestris

$$
\text { " " }
$$

jicranum polysetum

Pleurozium schreberi

Dicranum scoparium

Vaccinium myrtillus

Monotropa hypopitis

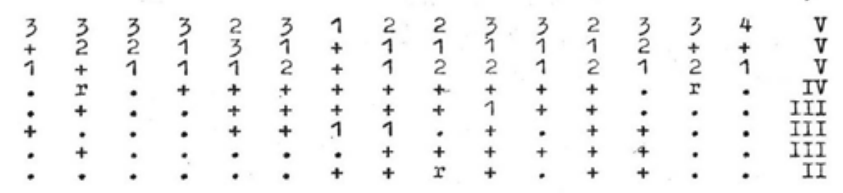

Accompanying species:

Gatunki towarzyszące:

Juniperus comsunis

Cladonia uncialis

Calluna vulgaris

Deschampsia flexuosa

Cladonia glauca

Pohlia nutans

Polytrichum juniperinum

Cladonia. cornuta

Quercus robur

Cladonia mitis

Pagus silvatica

Pagus silvatica

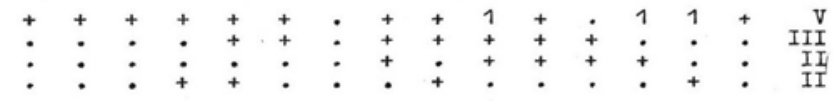
Sporadic in record /Sporadycznie w zdj./: 7 - Polytrichum piliferum +, Cladonia confocraea +;
8 - Pestuca ovina +; 9 - Cladonia minor +; 10 - Cetraria islandica +, Cladonia ochrochiora +; 11 - Thymus serpylium +. 
A floristic comparison of Cladonio-Pinetum from the Przymuszewo F. I. with phytocenoses of this association from other regions of northern Poland

Porównanie florystyczne Cladonio-Pinetum z nadleśnictwa Przymuszewo $\mathrm{z}$ fitocenozami tego zespołu $\mathrm{z}$ innych regionów Polski północnej

\begin{tabular}{|c|c|c|c|c|c|}
\hline $\begin{array}{l}\text { Name of species } \\
\text { Nazwa gatunku }\end{array}$ & -1 & 2 & 3 & 4 & 5 \\
\hline Cephaloziella starkei & V & V & & & \\
\hline Hypnum ericetorum & V & IV & & & \\
\hline Leucobryum glaucum & III & I & & I & \\
\hline Cladonia impexa & V & V & II & & \\
\hline Dicranum spurium & V & $\mathrm{V}$ & II & & \\
\hline Ptilidium ciliare & V & V & V & I & V \\
\hline Cornicularia aculeata & II & III & III & I & \\
\hline Peucedanum oreoselinum & & I & & III & III \\
\hline Arctostaphylos uva-ursi & & I & & III & II \\
\hline Scorzonera humilis & & & & II & IV \\
\hline Solidago virga-aurea & & & & II & IV \\
\hline Polygonatum odoratum & & & & II & II \\
\hline Anthericum ramosum & & & & II & I \\
\hline Cetraria islandica & & & I & I & II \\
\hline $\begin{array}{l}\text { Hieracium umbellatum var. } \\
\text { linariifolium }\end{array}$ & & & & & $\mathrm{V}$ \\
\hline Gypsophila fastigiata & & & & & III \\
\hline Koeleria glauca & & & & & III \\
\hline Dianthus arenarius & & & & & III \\
\hline Cetraria crispa & & & & & III \\
\hline Scleranthus perennis & & & & & II \\
\hline Convallaria maialis & & & & & II \\
\hline
\end{tabular}

1 - Łagów Lubuski F. I. (T o b o l e w s k i 1963); nadleśnictwo Łagów Lubuski ( $\mathrm{T}$ o b o l e w s k i 1963). 2 - Noteć Forest (Tobolewski 1963); Puszcza Notecka (T o bolewski 1963). 3 - north-western part of Bory Tucholskie; północno-zachodnia część Borów Tucholskich. 4 - Dobrzyń Upland (K ę p c z y ń s k i 1965); Wysoczyzna Dobrzyńska (K e p c z yń s ki 1965). 5 - Kurpie Forest (C z e r wiń s k 1970); Puszcza Kurpiowska (C z e r w ińs k i 1970).

the typically extremely poor (Table 3 , records 1-8), and the slightly richer, distinguished as the variant with Vaccinium myrtillus (Table 3, records 9-15); in Cladonio-Pinetum phytocenoses the vitality of this species is distinctly decreased.

A comparison of the patches of Cladonia-pine forest studied with comparative data (Tobolewski 1963; Czerwiński 1970; Sokołowski 1970a; Matuszkiewicz, Matuszkiewicz 1973), and with details from phytosociological papers (Sokołowski 1963; Kępczyński 1965; Kozak 1967; Zielińska 1967; Cieśliń$\mathrm{ski} 1979$, and others) shows that the dry pine forest in the Przymusze- 
wo F.I. as regards its floristic composition is most nearly similar to an analogous community in the Noteć Forest (Tobolew ski 1963) (Table 4). However, in the former the suboceanic bryophytes Hypnum ericetorum, Leucobryum glaucum and Cephaloziella starkei are missing, while Dicranum spurium and Cladonia impexa occur with lesser frequency. These species become rarer as one moves eastwards. At the same time, the community studied differs distinctly from Cladonio-Pinetum described from areas to the east of the Vistula (the Dobrzyn Upland - K ęp c z y ński 1965 and the Kurpiowska Forest - C z e rwinski 1970) in that subcontinental species are missing. The above facts demonstrate that Cladonio-Pinetum in the north-western Bory Tucholskie are an impoverished form of the suboceanic variant of this association.

Inland Cladonia-pine forests in Poland may have two possible origins. Some of them are the result of naturally extremely poor, dry habitats. These forests, although now usually consisting of planted pine stands, are growing on suitable soils, too poor for the development of richer phytocenoses. However, by far the larger number of Cladonia-pine forests has arisen as a result of erroneous management methods causing habitat degeneration. Such methods include the preference of pine, excessive felling, periodic agricultural use of the soil, cattle and swine grazing in forests and litter raking. This had led to anthropogenic forms of Cladonio-Pinetum growing on soils now impoverished but which were once covered at least in part with Leucobryo-Pinetum (see 4 and 7.3.1.), and in places with Pino-Quercetum and poor deciduous woodland. S okołowski (1980) has put forward the hypothesis that natural Cladonia-pine forest does not exist in Poland, and that all patches of it now found are degraded Vaccinio vitis-idaeae-Pinetum, Leucobryo-Pinetum or Pino-Quercetum phytocenoses. The natural and anthropogenic forms of Cladonia-pine forest now have a similar structure and composition and in most cases are indistinguishable in appearance. The forests in the Przymuszewo F.I. comprise mainly post-agricultural communities. Old maps and other archive information, also the frequent occurrence of tilth top soil in soil profiles are evidence of this.

\subsection{OTHER COMMUNITIES}

6.2.1. LEUCOBRYO-PINETUM, VACCINIO ULIGINOSI-PINETUM AND RAISED BOGS

Moist pine forest covers quite a large part of the studied area, but which is none the less incomparably smaller than the area under dry pine forest. The moist pine forest phytocenoses have been included in the Leucobryo-Pinetum association (Table 5) (see Sok ołowski 1965, who classified them as Vaccinio myrtilli-Pinetum).

This is a community of four distinct layers. The density of the tree 
Table 5 - Tabela 5

Leucobryo-Pinetum Mat./1962/1973

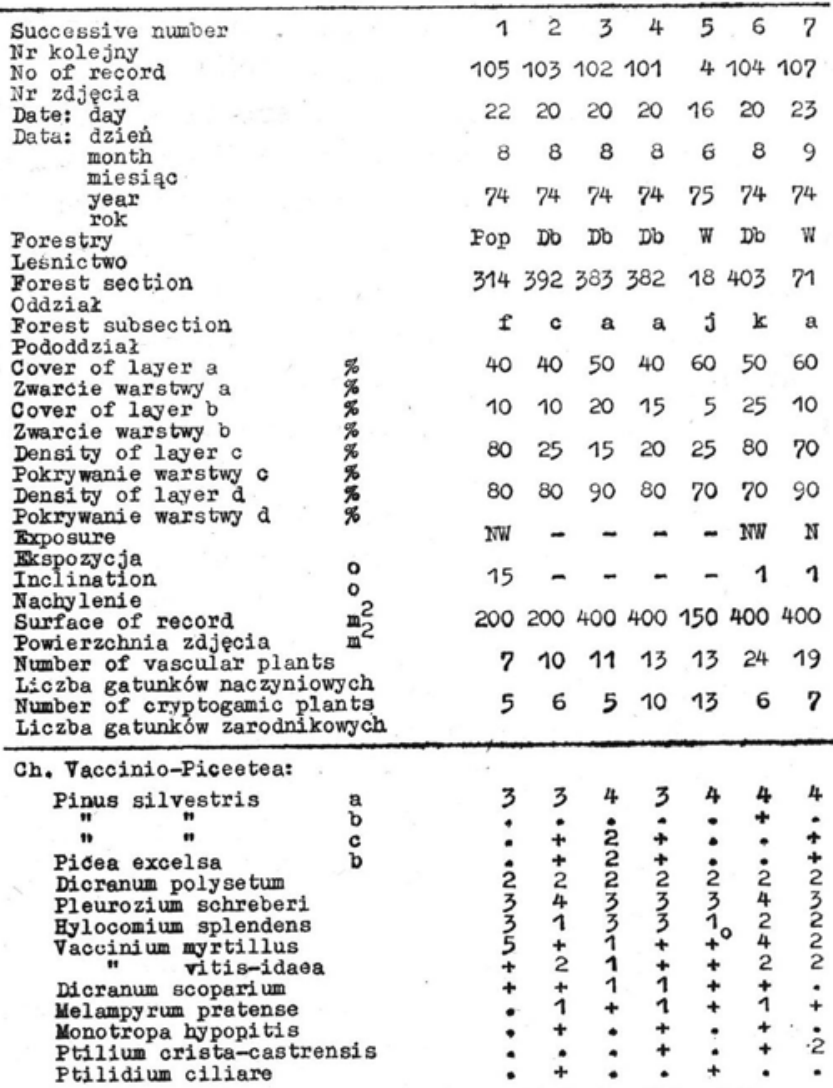

Sporadic in record /Sporadycznie w zdj./: 4 - Chimaphila umbellata +; 7 - Linnaea boreal is 2, Lycopodium annotinum 1, L. clavatum 1, Pirola secunda 1, Pseudoscleropodium purum + .

Accompanying species: Gatunki towarzyszące:

Vascular plants:

Roḱliny naczyniowe:

Juniperus comminis
Sorbus aucuparia
Prangula alnus
Betula verrucosa
Deschsmpsia flexuosa
Calluna vulgaris
Dryopteris spinulosa
Quercus sessilis
Rumex acetosella
Luzula multiflora
" pilosa

$b$
$c$
$b / c$
$b / c$
$b / c$

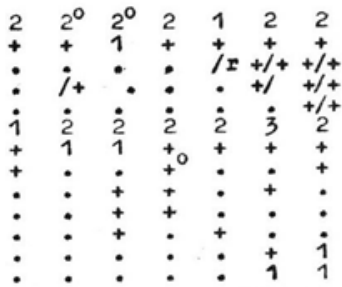

Pteridium aquilinum

Sporadic in record /Sporadycznie w zdj./: 3 - Carex pilulife$r a+; 5$ - Agrostis vulgaris 1, Anthoxanthum odoratum $r$, Fagus silvatica b: + , Pestuca ovina +; 6 - Calamagrostis arundinace + , Campanula rotundifolia + , Convallaria malaiis + , Festuca cfr. duriuscula + , Lathyrus montanus + , Kolinia coerulea + , Peucedanum oreoselinum + , Rubus saxatiis + , Rubus sp. +, Scorzonera humilis + , viola canina +; $7-$ Hieracium laevigatum + .

Iichens and bryophy tes: Porosty 1 mszaki:

Cladonia rangiferina

Aulacomnium palustre

Cladonia sylvatica " tenuis

Pohlia nutans

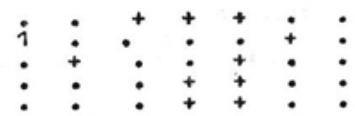

Sporadic in record /Sporadycznie w zdj./: 4 - cladonta floerkeana,$+ \mathrm{Cl}$. ochrochlora + ; 5 - Cladonia chlorophaea,$+ \mathrm{Cl}$. deformis $\mathrm{r}, \mathrm{Cl}$. furcata + , cl. glauca $\mathrm{r} ; \mathrm{7}$ - Ceratodon purpureus + , cladonia minor + . 
stand, exclusively Pinus silvestris, is not great, on average about $50 \%$. The underbrush comprises mainly Juniperus communis; rarely, one comes across a few other species. The herb layer is well developed with an average cover of $45 \%$; here Vaccinium myrtillus, V. vitis-idaea and Deschampsia flexuosa are predominant. Calluna vulgaris is always present. The very abundant "d" layer is dominated by the mosses Pleurozium schreberi, Dicranum polysetum and Hylocomium splendens. Terricolous lichens are found in very small number in the drier patches (Table 5 , records 4 and 5) or on slight rises in the terrain; their importance in this community is negligible.

Leucobryo-Pinetum in the Przymuszewo F.I. can be included in the Pomerania-Silesia variant (Matuszkiewicz, Matuszkiewi c z 1973) which is distinguished by the constant and fairly considerable presence of Deschampsia flexuosa. Convallaria maialis, Lathyrus montanus, Peucedanum oreoselinum, Rubus saxatilis and Scorzonera humilis are to be found in some patches of moist pine forest, especially in the eastern part of the studied area, which thus shows connections with Peucedano-Pinetum (Table 5, record 6). Matuszkiewicz and Matuszkiewicz (1973) suggested that this type of phytocenosis may be a degenerate form of Pino-Quercetum. Historical data for the studied area show that this could well be possible (Boins si 1976).

In many parts of the Bory Tucholskie, wrong management methods have transformed the moist pine forest into Cladonia-pine forest (see 7.3.2.). In private forests, especially in the vicinity of Wiele and Dąbrowa, large-scale litter raking from pine monocultures in Leucobryo-Pinetum habitats has caused the complete disappearance of herb layer vegetation. In patches several hundred square metres in area and larger nothing but 20 - to 40 -year old pines are to be found.

In the Przymuszewo F.I. Vaccinio uliginosi-Pinetum Kleist 1929 covers but a very small area and does not provide a favourable environment for lichen growth. They occur there sparsely on the tops of dried out hummocks and around the bases of pine trunks. These are primarily Cladonia species, more rarely Lecidea spp. and Lepraria aeruginosa. Epiphytic lichens, mostly Hypogymnia physodes, Lecanora conizaea, Pseudevernia furfuracea, Lepraria aeruginosa, Lecidea scalaris, Bacidia chlorococca and Usnea hirta grow on pines and small shrubs, especially on Ledum palustre and Calluna vulgaris.

Raised and transition bogs are a characteristic element of the landscape in the studied area. They do not cover a large area, although the plant communities of raised and transition bogs or parts of them are often found around the fringes of lakes and in kettles. No lichens were found on transition bogs; they are always present in raised bog communities although not of any great importance. They grow in small 
numbers on the tops and sides of old hummocks. Cladonia chlorophaea, $\mathrm{Cl}$. bacillaris, $\mathrm{Cl}$. impexa and $\mathrm{Cl}$. minor were most often found in these habitats.

\subsubsection{HEATHS AND PSAMMOPHILOUS SWARDS}

Communities in which Calluna vulgaris is very common are frequent in the Przymuszewo F.I. They cover a substantial part of most rides from 5 to 15-metre wide, also fire-prevention strips which are up to 50-metre wide and several kilometer long (Fig. 10). Heaths exist mainly in Cladonio-Pinetum habitat, more rarely in Leucobryo-Pinetum and Vaccinio uliginosi-Pinetum. In the latter two habitats the heathlands take on a mossy appearance and lichens here are few in number.

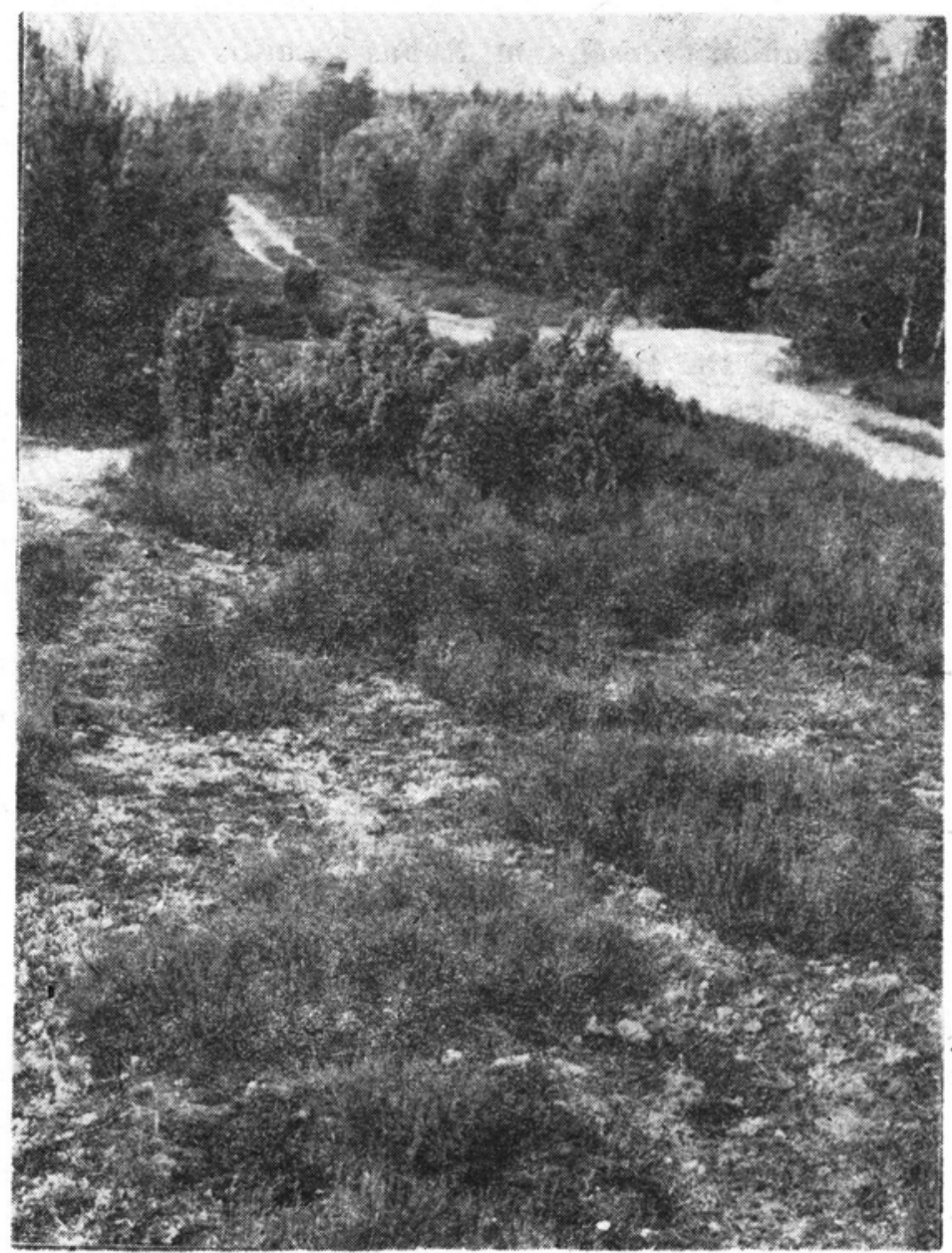

Fig. 10. Heath on the ride in the dry pine wood (Photo J. Herbich)

Ryc. 10. Wrzosowisko na linii oddziałowej w borze suchym (fot. J. Herbich) 


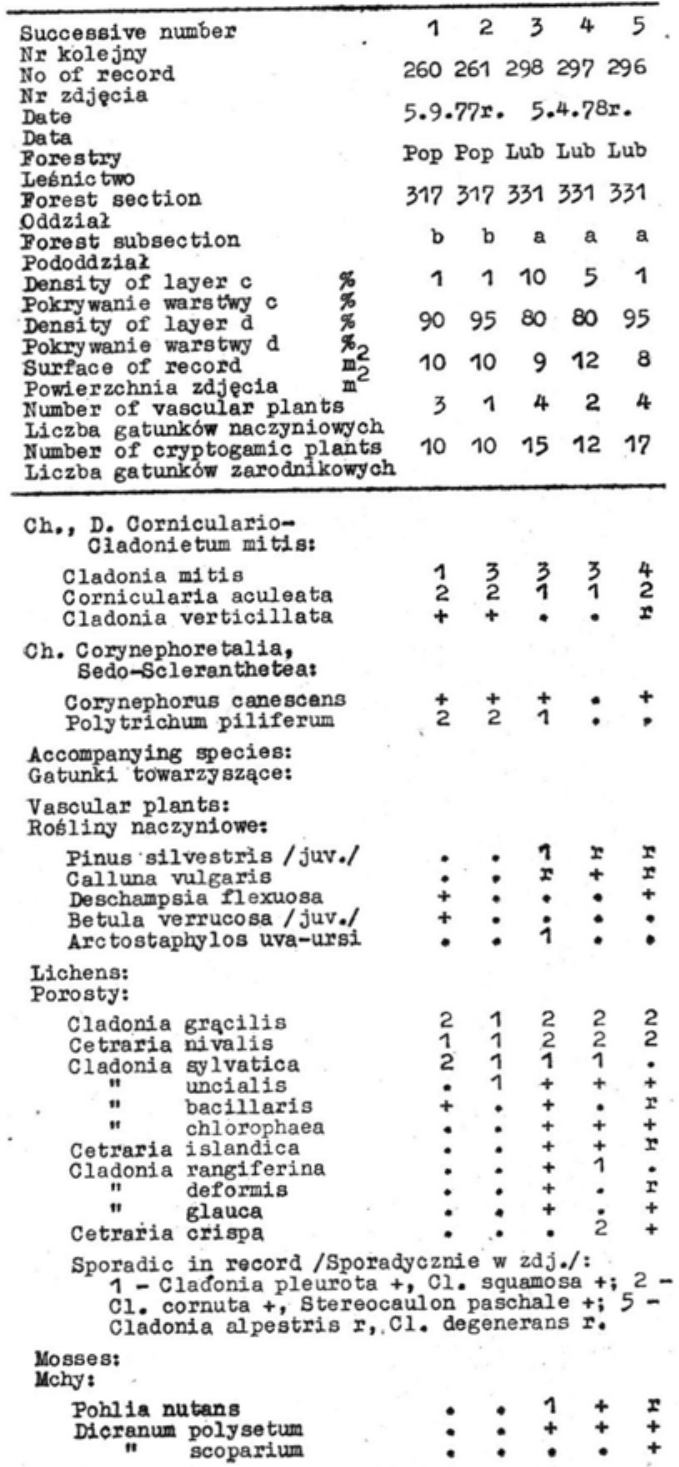

A Calluna vulgaris community consists basically of two layers. Trees and shrubs, i.e. Pinus silvestris and Juniperus communis occur sporadically and singly. Calluna vulgaris absolutely dominates in the "c" layer and other vascular plant species are found but rarely and then in very small number. The average cover of this layer is around $60 \%$. The bryophyte-lichen layer is highly developed - average cover about $95 \%$ - and abundant in species - on average 22 per record. In most patches lichens are by far the more important and include Cladonia 
Table 7 - Tabela 7

Spergulo-Corynephoretum /Tx. 1928/ Libb. 1933

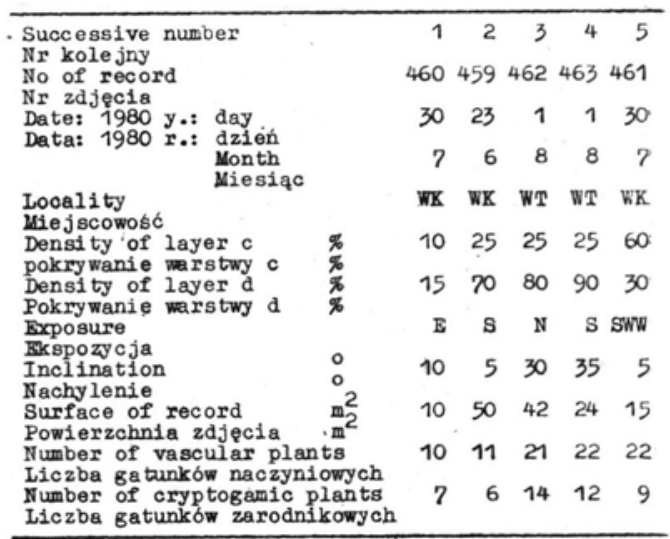

\begin{tabular}{llllll}
\hline Ch. Spergulo-Corynephore tum: & & & & & \\
Corynephorus canescens & 1 & 2 & 1 & + & 2 \\
Teesdalea nudicaulis & + & + & $:$ & + & $\mathbf{r}$ \\
Pilago minima & + & $\mathbf{r}$ & $\mathbf{1}$ & $\mathbf{+}$ &
\end{tabular}

Ch. Corynephoretalia,

Sedo-screranthe tea:

Polytrichum piliferum

Rumex acetosella

Thymus serpyllum

Ceratodon purpureus

Cornicularia aculeata

Jasione montana

Scleranthus perennis

Rhacomitrium canescens

Trifollum arvense

Helichrysum arenarium

Artemisia campestris

Sedum acre

Arenaria serpyllifolis

Brachy thecium albicans

Festuca ovina

$\begin{array}{lllll}+ & 4 & 3 & + & 2 \\ 1 & 2 & 1 & 1 & 1 \\ + & 1 & 1 & 1 & 2 \\ 2 & 1 & 1 & + & 1 \\ + & + & + & + & + \\ : & + & + & + & 1 \\ : & : & 2 & + & 2 \\ : & : & + & + & + \\ : & : & + & + & + \\ : & : & 2 & : & 2\end{array}$

Accompanying species:

Gatunki towarzyszące:

Vascular plents:

Rośliny naczyniowe:

Hieracium pilosella

Pestuca rubra

Agrostis vulgaris

Convolvulus arvensis

Veronica triphyllos

Potentilla argentea

Frigeron acer

Achillea millefolium

Sporadic in record /Sporadycznie $\mathbf{z d j} /$

1 - Carex hirta +, Holcus lanatus $\mathbf{S}^{\circ}$; 2 - Arnoseris minima $r ; 3$ - Calamintha aoinos + , Bromus mollis $r$, Vicia oracca + , Linaria vulgaris $r$, Papaver dubium $r$; 4 - Agropyron repens +, Anthgxanthum odoratum +, Fagopyrum sagittatum + + , Silene venosa + , viola arvensis +; 5 - Hierniaria glabra 1, Hypochoeris radicata + , Artemisia absinthium + , Pinus silvestris + , Plantago lanceolata + , Trifolium dubium + , Vicia angustifolia + , V. hirsuta + .

Zichens and bryophytes:

Porosty i mszaki:

Cladonia mitis

$\begin{array}{ll}\text { " } & \text { cornutoradiata } \\ " & \text { uncialis } \\ " & \text { verticillata } \\ \text { " chlorophaea }\end{array}$

Sporadic in record/Sporadycznie w zdj./: 1 - Dicranum scoparium +; 2 - Lecidea granulosa $+; 3$ - Cephaloziella starke + , Cladonia degenerans $t$. Cl. pleurota $t: 4-c 1$. bacillotinor + , Pohlia nulans + ; $;$ - Peltigera spuria + . 
mitis, Cl. gracilis (as the variants: var. gracilis, var dilatata and var. dilacerata), $\mathrm{Cl}$. uncialis, $\mathrm{Cl}$. chlorophaea, $\mathrm{Cl}$. rangiferina and Cornicularia aculeata. The following species of coniferous forest bryophytes are quite common: Pleurozium schreberi, Dicranum scoparium, D. polysetum, Ptilidium ciliare, and besides these Polytrichum piliferum and Pohlia nutans.

Characteristic of these heaths are the ever-present and fairly numerous subatlantic cryptogamic plants such as Ptilidium ciliare, Cornicularia aculeata, Cephaloziella starkei, Dicranum spurium and Cladonia impexa. In the eastern part of the forestry area, near Lubnia and Wiele, some of these species are less numerous and occur more rarely. They are replaced by the subcontinental Cetraria crispa and C. islandica, and in many places by Arctostaphylos uva-ursi.

In the forest complex between Lubnia and Wiele a specific community of cryptogamic plants with Cetraria nivalis has formed on some rides (Table 6) (Fałtynowicz, Tobolewski 1980). The floristic composition and numerical relationships are such that these phytocenoses can be included in the Corniculario-Cladonietum mitis association (see C ieśliński 1979; Faliński 1980 ; Krotoska, Tobolew ski 1980). In older publications, similar plant communities were described as forms of the Corynephoretum canescentis or Spergulo-Corynephoretum associations (e.g. Zi elińska 1967; Halicz, Godlew ski 1968).

There are very few herbaceous plants in the Corniculario-Cladonietum mitis associations investigated (average cover up to $5 \%$ ). Bryophytes and lichens cover most of the area (average cover approx. 90\%), and include Cladonia mitis, $\mathrm{Cl}$. gracilis, Cornicularia aculeata, Cetraria nivalis and Cladonia sylvatica. Of the bryophytes only Polytrichum piliferum occurs at all abundantly.

Near some villages and forest settlements one occasionally finds areas of grassland once cultivated where lichens occur. These areas are represented by the records in Table 7 . Such a community can be classified as an anthropogenic form of the Spergulo-Corynephoretum association. The records in the table are arranged according to the age of the phytocenosis, from the youngest (rec. 1 - about 10 years, rec. 2 12 years) to the oldest (over 20 years). Polytrichum piliferum is particularly common in record 2. Some authors describe such patches in which this species is very common as an independent community (see Cieśliński 1979; Krotoska, Tobolewski 1980). Cieśliński (1979) considers phytocenoses with Polytrichum piliferum to be "[...] a pioneer group initiating vegetation on a poor, loose, sandy substrate with favourable conditions of humidity". It would appear that in the studied area the initial stage of post-arable grasslands is pioneered by a community dominated by Ceratodon purpureus, whereas Polytri- 
chum piliferum forms the next, more advanced stage in the development of the vegetation.

Patches of Spergulo-Corynephoretum are rare in the north-western Bory Tucholskie, and in recent years their area has decreased substantially as a result of the afforestation of fallow land or re-planting, mainly with Fagopyrum sagittatum.

\section{CHANGES IN THE LICHEN FLORA BROUGHT ABOUT BY NATURAL AND ANTHROPOGENIC FACTORS}

\subsection{CHANGES TAKING PLACE WITH THE GROWTH OF PINE STANDS}

\subsubsection{TERRICOLOUS LICHENS}

Little information is available about secondary succession in forest communities where lichens are common. Detailed studies have been carried out in the Canadian taiga (S c otter 1964; M a i ka wa, K e r$\mathrm{sh} \mathrm{aw} \mathrm{1976)} \mathrm{and} \mathrm{in} \mathrm{the} \mathrm{South-Eastern} \mathrm{U.S.A.} \mathrm{(Robinson} \mathrm{1959,} \mathrm{cited} \mathrm{by}$ $\mathrm{H}$ a le 1974). In the Polish literature mention of secondary succession in dry pine forests is made only in the papers by Tobolew ski (1963) and $\mathrm{Zielinska}$ (1967). In addition to this, Mows zowicz (1956), and Rydzak and $\mathrm{Zabinska}$ (1972) studied the initial stages of colonization of bare surfaces in Cladonia-pine forests. Markowski $(1971,1974,1982)$ and Sok ołowski (1970b, 1980) described the secondary succession of felled areas in Vaccinio myrtilli-Pinetum, Empetro nigri-Pinetum, Pino-Quercetum and deciduous forest habitats.

The evaluation of this problem and the interpretation of results are difficult, the more so because the course of succession in managed forests is interrupted at many points by man (see chapter 4).

\subsubsection{Comments on the method}

Pine phytocenoses from 5- to 76-year old were studied. The basic material which was later analysed was obtained from phytosociological records made in $8610 \times 15 \mathrm{~m}\left(150 \mathrm{~m}^{2}\right)$ areas in plantations, boskets and pine stands. These were broken down into 8 age groups:

$$
\begin{array}{cr}
\text { I }- \text { 5-7 years, } & \text { V }-41-44 \text { years, } \\
\text { II }-13-14 \text { years, } & \text { VI }-56 \text { years, } \\
\text { III }-19-22 \text { years, } & \text { VII }-65-66 \text { years, } \\
\text { IV }-28-31 \text { years, } & \text { VIII }-\quad 76 \text { years. }
\end{array}
$$

These age groups have nothing in common with the age classes for trees used in forestry. The age differences of pine between the various groups is 6 years in plantations and boskets, and 10 years in older stands. This breakdown was based on the assumption that changes take place much more rapidly in younger plantations than in older stands; this was confirmed by the results. From 8 to 18 phytosociological records were made in each of the above age groups. 
The felling of a tree stand and the removal of the timber from the felling area, the subsequent replanting with pine brings about tremendous changes in the habitat (see chapter 4), and thus in the flora. The vegetation in the felling area is devastated to such an extent that of the forest herb and moss-lichen layer there remain but a few, usually broken, specimens of lichens (Cladonia sylvatica, Cl. rangiferina, Cl. uncialis, Cl. gracilis and others), trampled bryophytes (Pleurozium schreberi, Dicranum polysetum) and single examples of Calluna vulgaris, Vaccinium vitis-idaea and V. myrtillus. Whereas their spatial importance is practically nil, their ecological importance is very great; they have become the starting point for the development an expansion of these species (apart from fragments of thalli, soredia, spores and seeds carried on to the felling area from its surroundings). The succession begins practically from the nullpoint, on a thin layer of sand devoid of humus.

The results of studies on secondary succession in the Cladonio-Pinetum habitat, presented in Fig. 11, show that four fundamental stages in the development of the herb and moss-lichen layer of a Cladoniapine forest can be distinguished:

1. colonization and domination by heliophilous species - up to 7-10 years after felling;

2. coexistence of heliophilous and shade-tolerant species (from 7-10 to $20-25$ years);

3. mossy (from $20-25$ to $40-45$ years);

4. typically formed Cladonia-pine forest phytocenoses (over 40-45 years).

Characteristic of the first stage is the appearance of plants from sward and post-felling communities; forest species are practically nonexistent. The most numerous cryptogamic plants are crustose lichens from the genus Lecidea: L. granulosa, L. humosa and L. uliginosa, and also Ceratodon purpureus. These plants, especially the Lecidea spp., are biologically very important in the initial succession stage and one might say they constitute a forecrop. Their thalli, covering the dense crust of sand, largely inhibit wind and water erosion, they prevent the substrate from drying out and, after dying, establish the beginnings of a humus layer. Other cryptogamic plants play a negligible part in the first stage of succession. As regards vascular plants, Corynephorus canescens and Senecio silvaticus appear in small numbers - these species are foreign to the typical Cladonio-Pinetum phytocenoses. Spergula vernalis also occurs this time in quite large number, giving an average cover of $6.8 \%$. Apart from these, Deschampsia flexuosa is seeded in quite large number, and Calluna vulgaris regrows from underground stolons.

The moment the first plants appear among the planted pines, the 


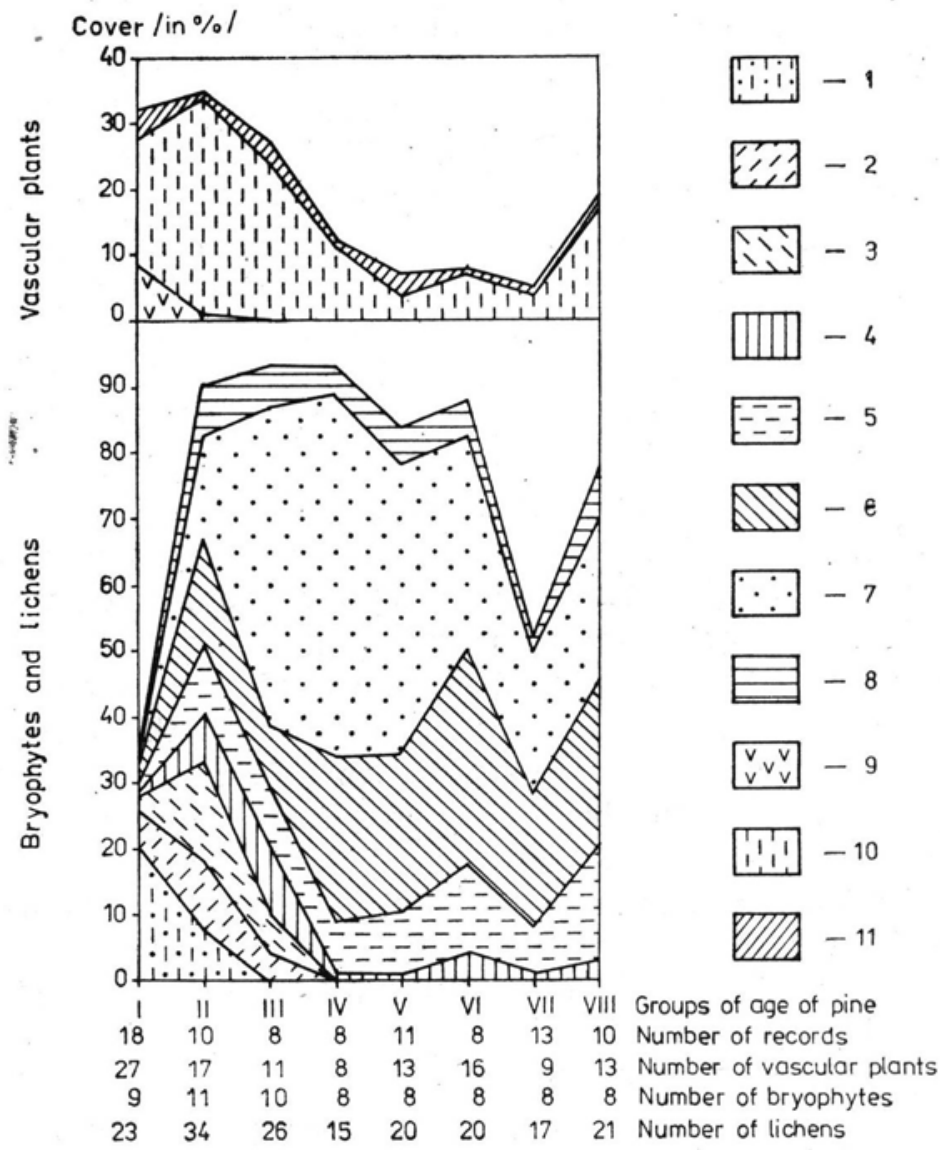

Fig. 11. Dynamics of the plants involved in the succession on a Cladonio-Pinetum. habitat

1 - Lecidea granulosa, L. humosa and L. uliginosa, 2 - Ceratodon purpureus and Polytrichum piliferum, 3 - Cladonia bacillaris, $\mathrm{Cl}$. cornuta, $\mathrm{Cl}$. degenerans and $\mathrm{Cl} . \mathrm{mitis,} 4-$ Pohlia nutans, 5 - Cladonia gracilis and $\mathrm{Cl}$. uncialis, 6 - Cladonia rangiferina and $\mathrm{Cl}$. sylvatica, 7 - Dicranum polysetum and Pleurozium schreberi, 8 - other bryophytes and lichens, 9 - Corynephorus canescens, Senecio silvaticus and Spergula vernalis, 10 - Calluna vulgaris and Deschampsia flexuosa, 11 - other vascular plants

Ryc. 11. Dynamika roślin runa uczestniczących w sukcesji na siedlisku CladonioPinetum

1 - Lecidea granulosa, L. humosa 1 L. uliginosa, 2 - Ceratodon purpureus 1 Polytrichum piliferum, 3 - Cladonia bacillaris, $\mathrm{Cl}$. cornuta, $\mathrm{Cl}$. degenerans i $\mathrm{Cl}$. mitis, 4 - Pohlia nutans, 5 - Cladonia gractlis i $\mathrm{Cl}$. uncialis, 6 - Cladonia rangiferina i Cl. sylvatica, 7 - Dicranum polysetum 1 Pleurozium schrebei, 8 - inne mszaki 1 porosty, 9 - Corynephorus canescens, Senecio silvaticus i Spergula vernalis, 10 - Calluna vulgaris i Deschampsia flexuosa, $11-$ inne rosliny naczyniowe

forest species begin their gradual expansion which continues until, after 20-30 years, they have entirely superseded the non-forest species (Fig. 12). The period between the 7-10th and 20-25th year of succession is a transition stage between the non-forest community represented by the pine plantations and fairly open boskets and the forest community, which 


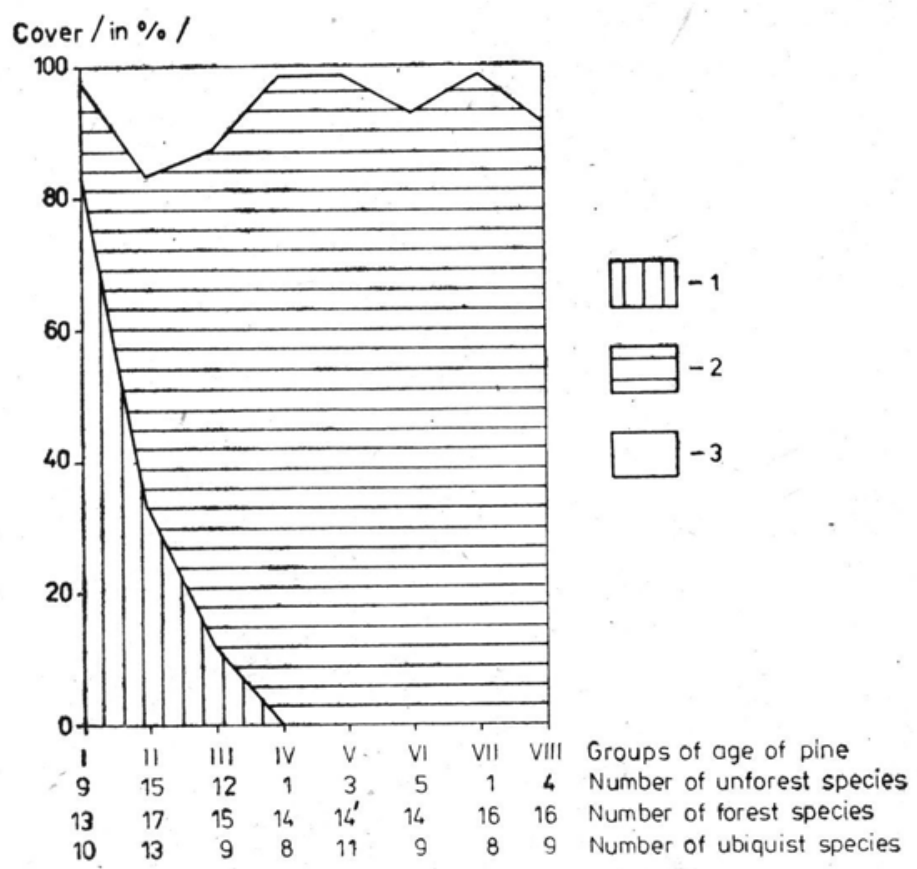

Fig. 12. Relative numbers of non-forest (1), forest (2) and ubiquitous (3) species in the succession of cryptogamic plants in the moss-lichen layer of a CladonioPinetum habitat

Ryc. 12. Względny udział gatunków nieleśnych (1), leśnych (2) i ubikwistycznych (3) w sukcesji roślin zarodnikowych runa na siedlisku Cladonio-Pinetum

should include all phytocenoses containing 15-20-year old and older pines with a density of over $50 \%$. This transition is reflected by the flora: typical of the second stage of succession is the coexistence of non-forest and forest species, the former tending to give way to the latter (Figs. 11, 12). Lichens of the genus Lecidea are still numerous, Cladonia mitis (Fig. 13), Cl. bacillaris and Polytrichum piliferum occur in relatively large numbers. But besides these non-forest taxons, the forest species Cladonia sylvatica, Cl. rangiferina, Dicranum polysetum and Pleurozium schreberi (Fig. 11) have-become co-dominant. Among the vascular plants, Calluna vulgaris reaches its optimum development in these phytocenoses, but declines with the increase in shade.

As the pines grow, so does the tree density and this in turn alters the microclimate of the bosket (see chapter 4). Insolation and air movement are now much reduced, the humidity of the soil and air increased. These changes make the habitat less favourable to lichens and more so to bryophytes. Thus the path towards typical Cladonia-pine forest phytocenoses goes through a mossy stage. The pine thickets appear to be more moist than dry, whit Dicranum polysetum and Pleu- 

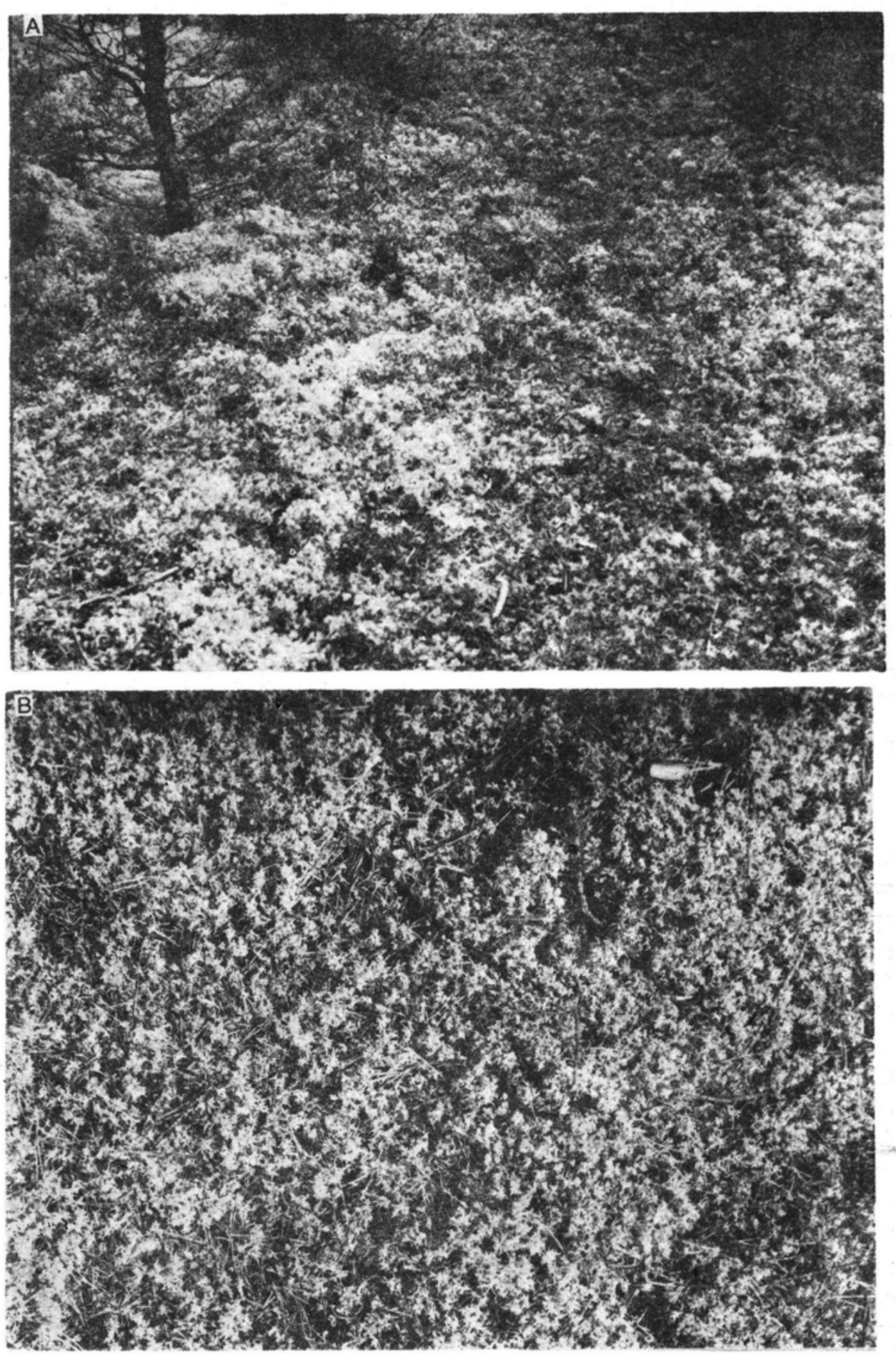

Fig. 13. 15-year old pine bosket (Photo J. Herbich)

A - general view, B - moss-lichen layer with dominant Cladonia mitis

Ryc. 13. 15-letni młodnik sosnowy (fot. J. Herbich)

A - widok ogólny, B - runo $\mathrm{z}$ dominacją Cladonia mitis 
rozium schreberi dominating the moss-lichen layer. Lichens make up small synusial concentrations - these are chiefly Cladonia sylvatica, $\mathrm{Cl}$. rangiferina and $\mathrm{Cl}$. gracilis; $\mathrm{Cl}$. uncialis is rarer. The specific microclimate of 20-40-year old phytocenoses is responsible for the fact that almost all the species present here are forest ones; non-forest species are entirely absent, while ubiquists occur rarely and singly (Fig. 12).

In managed Cladonia-pine forests, the "way out" of the mossy stage is accelerated by man: thinning reduces the tree density, and lowers the air humidity, more light reaches the ground cover. Under such conditions lichens become more active: their numbers increase, while bryophytes become less important. The quantitative relationships between lichens and bryophytes become stabilized in 40-50-year old stands: 40$50 \%$ of the area is occupied by lichens, $25-30 \%$ by bryophytes and $20-$ $30 \%$ remains free of cryptogamic plants. These numerical relationships are characteristic of the typical Cladonia-pine forest phytocenoses in the studied area. The relationships between these groups of plants are established later than the stabilization of the species content of coniferous forest phytocenoses; this latter takes place at the mossy stage, i.e. in 20-40-year old plantations (Fig. 11).

In typical patches of Cladonio-Pinetum, the moss-lichen layer is dominated by six taxons: Cladonia sylvatica, $\mathrm{Cl}$. rangiferina, $\mathrm{Cl}$. uncialis, Cl. gracilis, Dicranum polysetum and Pleurozium schreberi. Other species are of little spatial importance. On the other hand, during the entire succession process in the Cladonia-pine forest habitat, barely 16 taxons (Fig. 11) out of a total of 38 species of lichens and 12 bryophytes found were of any consequence in the cryptogamic plant layer.

The vascular plants of the herb layer only a small part in the secondary succession in the Cladonio-Pinetum habitat. They occur in greater number only during the first thirty years (mostly Calluna vulgaris) and in the oldest illuminated stands (primarily Deschampsia flexuosa) (Fig. 11).

\subsubsection{Discussion}

The scope of this studies on the primary and secondary succession in Cladonia-pine forest habitats carried out so far has been restricted to regions where communities of this type are of considerable economic moment, i.e. in the USA and Canada (e.g. Robinson 1959, quoted by $\mathrm{H}$ a le 1974). The results of these studies approximate to those presented in this thesis. They were carried out in pine-afforested areas in Piedmont where the author investigated the succession of species and communities which have existed there since the establishment of the plantation over 100 years ago (Robinson 1959, quoted by $\mathrm{H}$ a le 1974). In the first stage, lichens, especially Cladonia species, dominate the open 
areas. They reach their peak of abundance and largest number of species from 10 to 40 years after the establishment of the plantation. The most species are found in 15-24-year old plantations, rather fewer in 1014-year old plantations. After about 40 years the lichen cover gradually diminishes as a result of excessive shade, needle fall and the accumulation of humus and litter.

The regeneration of the moss-lichen layer in forest after fires has been described i.e. by Mows zowicz (1956), S c otter (1964), and Maikawa and Kershaw (1976). Here one should make a clear distinction between the regeneration of the moss-lichen layer after fire in woodland of very low density or in which the tree stand has been destroyed, and the regeneration of the lower layers of vegetation after a fire which has left the tree layer intact. In the first case (see S c otter 1964; Maikawa, Kershaw 1976), the process is similar to the secondary succession described in this thesis. M a i k a w a and $\mathrm{Ker-}$ $\mathrm{s} \mathrm{h}$ a w (1976) distinguished four stages of succession after a fire on the Canadian taiga: the first, lasting 20 years, is dominated by Polytrichum piliferum, Lecidea granulosa and L. uliginosa; in the second, from the 21 st to the 60th year, Cladonia stellaris and $\mathrm{Cl}$. uncialis predominate; in the third stage (61-130 years), spruce forest with dominant Sterocaulon paschale is formed; in the fourth stage, starting with 130-year old tree stands, the shade causes a reduction in the lichen cover and favours the expansion of bryophytes. The final stage of succession is a moss-spruce forest.

The regeneration of the moss-lichen layer of a Cladonia-pine forest after a fire which left the tree stand intact was studied by Mow s z owic z (1956). This differs from the regenerations described above primarily in that the presence of a tree layer and its influence on the microclimate favour shade-preferring species from the very start for the renewal of vegetation in the burnt out areas. According to Mow s z o$\mathrm{wicz}$ (1956), the lichen layer requires from 30 to 60 years for its complete regeneration. This is a time span similar to that necessary for the formation during a secondary succession of the moss-lichen layer typical of Cladonio-Pinetum.

The overgrowth of bare surfaces in a Cladonia-pine forest (R y$\mathrm{dzak}, \quad \dot{Z} \mathrm{abińska} 1972$ ) takes place in much the same way as the regeneration process described by Mowszowicz (1956).

The secondary succession stages in Vaccinio myrtilli-Pinetum and Vaccinio vitis-idaeae-Pinetum habitats described by Sokołowski (1970b, 1980) differ from those taking place in Cladonio-Pinetum: the part played by lichens is much diminished and mosses dominate (mainly Pleurozium schreberi); there is also a greater species differentiation among the vascular plants of the herb and moss-lichen layers. In S ok o łowski's opinion, very dense pine boskets in a moist pine forest 
habitat at the age of 20-25 years do not differ from mature stands of Vaccinio myrtilli-Pinetum either in their floristic composition or in their quantitative relationships in the herb and moss-lichen layers.

\subsubsection{EPIPHYTIC LICHENS ON PINUS SILVESTRIS}

Pine bark provides specific living conditions for epiphytes, which are different from those of most other trees. It is deeply furrowed, especially in specimens over 30-year old. Besides this, the bark flakes continuously, which restricts the occurrence of many species and limits the area on which lichens can grow to the branches and the first three or four metres of the trunk (rarely higher). B rodo (1973) classifies Pinus bark as acid and oligotrophic - the ash content varies from 0.4 to $2.7 \%$; eutrophic bark, for example, in Acer pseudoplatanus, contains (5) $8-15 \%$ ash. Pine bark has a very low water capacity and a high coefficient of transpiration. Thus xeric plants find suitable conditions for existence here (B a r k m a n 1969; B r od o 1973) which are intensified by habitat factors on pines growing in a dry pine forest.

\subsubsection{Comments on the method}

The epiphytic lichens on Pinus silvestris were studied not only in order to discover their species content but also to define the changes which take place in the bark flora as the pine increases in height. Therefore, apart from floristic notes taken for the purpose of campiling a lichen flora of the studied area, 300 pines were selected at random in particular age classes and a note made of every species found up to a height of $\pm 4 \mathrm{~m}$, its position on the trunk, abundance etc. In this way, 50 trees from each age class, i.e. Ia - 1-10 years, Ib - 11-20, II-21-40, III $-41-60$, IV $-61-80, \mathrm{~V}-$ over 80 years, were analysed. At the same time, the height and d.b.h. of each pine were measured; the d.b.h. was not measured in age class Ia there were very few trees reaching a height of over $1.3 \mathrm{~m}$.

\subsubsection{The succession of epiphytes}

Lichens appear on the bark of very young pines. Near the bottom on the first ring of branches of 3-4-year old trees one can find tiny thalli of Lecanora conizaea apothecia and the first patches of Hypogymnia physodes. The lower trunks and lower rings of branches of 5-10-year old pines have an abundant, sometimes very dense, covering of Lecanora conizaea. Other species in this age class occur sporadically, e.g. Bacidia chlorococca, Lepraria aeruginosa and flakes of the primary thallus of Cladonia spp. (Table 8). On the lower parts of 11-20-year old pines Lecanora conizaea is very numerous; somewhat less abundant are Hypogymnia physodes and Bacidia chlorococca. Single, tiny thalli of Cetraria 
Zmiany we florze epifitycznej sosen w różnych klasach wieku w monokulturach so snowych na siedlisku Cladonio-Pinetum

\begin{tabular}{|c|c|c|c|c|c|c|}
\hline $\begin{array}{l}\text { Class of age of pine } \\
\text { Klasa wieku. sosny } \\
\text { Mean d.b.h. / in cm/ } \\
\text { Srednia piersnica / } \mathrm{w} \mathrm{cm/} \\
\text { Mean heath / in m/ } \\
\text { Srednia wy sokośc / w m/ } \\
\text { Number of species: mean } \\
\text { Liczba gatunków: srednia } \\
\text { total } \\
\text { ogóle.a }\end{array}$ & $\begin{array}{c}1.8 \\
-\frac{5}{\mathrm{P}}-\frac{-}{\mathrm{K}}\end{array}$ & $\begin{array}{c}3.5 \\
13 \\
-\frac{P}{\mathrm{P}}\end{array}$ & $\frac{19}{\mathrm{P}}-\frac{-}{\mathrm{K}}$ & $-\frac{19}{\mathrm{P}}-\frac{-}{\mathrm{K}}$ & $-\frac{23}{P}-\frac{}{K}$ & $\begin{array}{c}7.3 \\
21 \\
--- \\
\mathrm{K}\end{array}$ \\
\hline $\begin{array}{l}\text { Hypogymnia physodes } \\
\text { Lecanora conizaea } \\
\text { Lepraria aeruginosa } \\
\text { Cladonia sp. } \\
\text { Bacidia chlorococca } \\
\text { Cetraria sepincola } \\
\text { Lecanora umbrina } \\
\text { Cladonia chlorophaea } \\
\text { Lecanora conizaeoides } \\
\text { Pseudevernia furfuracea } \\
\text { Lecidea scalaris } \\
\text { Parmeliopsis ambiqua } \\
\text { Cladonia glauca } \\
\text { Cetraria glauca } \\
\text { Cladonia digitata } \\
\text { Parmeliopsis aleurites }\end{array}$ & $\begin{array}{rr}34 & \text { IV } \\
47 & \text { V } \\
4 & \text { I } \\
2 & \text { I } \\
3 & I\end{array}$ & $\begin{array}{rr}49 & V \\
50 & V \\
3 & I \\
3 & I \\
29 & \text { III } \\
29 & \text { III } \\
8 & I \\
2 & I \\
3 & I \\
& \\
2 & I\end{array}$ & $\begin{array}{lr}50 & \mathrm{~V} \\
50 & \mathrm{~V} \\
23 & \text { III } \\
18 & \text { II } \\
24 & \text { III } \\
18 & \text { II } \\
22 & \text { III } \\
18 & \text { II } \\
11 & \text { II } \\
22 & \text { III } \\
& \\
3 & I \\
2 & I \\
2 & I \\
1 & I\end{array}$ & \begin{tabular}{|rr}
50 & V \\
50 & $\mathrm{~V}$ \\
41 & $\mathrm{~V}$ \\
26 & III \\
21 & III \\
2 & $\mathrm{I}$ \\
2 & $\mathrm{I}$ \\
9 & $\mathrm{I}$ \\
4 & $\mathrm{I}$ \\
46 & $\mathrm{~V}$ \\
4 & $\mathrm{I}$ \\
6 & $\mathrm{I}$ \\
8 & $\mathrm{I}$ \\
8 & $\mathrm{I}$ \\
2 & $\mathrm{I}$
\end{tabular} & $\begin{array}{rr}50 & V \\
46 & V \\
50 & V \\
24 & \text { III } \\
5 & I \\
2 & I \\
8 & I \\
6 & I \\
48 & \text { V } \\
30 & I I I \\
17 & \text { II } \\
15 & \text { II } \\
8 & I \\
4 & I \\
7 & I\end{array}$ & $\begin{array}{rr}50 & V \\
34 & \text { IV } \\
50 & V \\
26 & \text { III } \\
7 & \text { I } \\
2 & I \\
4 & I \\
4 & I \\
46 & \text { V } \\
44 & \text { V } \\
22 & \text { III } \\
13 & \text { II } \\
18 & \text { II } \\
16 & \text { II } \\
13 & \text { II }\end{array}$ \\
\hline 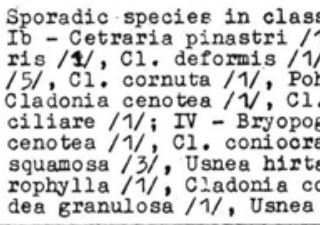 & occur & $\begin{array}{l}/ 1 / 19 \\
\text { a } / 1 / 1, \\
\text { defo } \\
\text { Bryopo }\end{array}$ & $\begin{array}{l}\text { adon } \\
\text { is / }\end{array}$ & enie & $\mathrm{Pt}$ & $\begin{array}{l}\text { lla- } \\
\text { aea } \\
\text { m } \\
\mathrm{Cl}_{\text {hlo- }}\end{array}$ \\
\hline
\end{tabular}

Bxplanations: $P$ - number of occurrences, $K$ - constancy

Objasnienia: P - liczba wystapien, $\mathrm{B}$ - staróćc

sepincola, though usually with apothecia can be found on the thin branches of many trees.

Lichens cover the branches and trunks of pines of age class II up to a height of 1.5-3 m. Hypogymnia physodes predominates on the trunks, while Cladonia spp. are often found only as primary thalli at their bases. The branches are thickly covered with Lecanora conizaea, and Hypogymnia physodes is also abundant here. Bacidia chlorococca, Cetraria sepincola, Lecanora umbrina and L. conizaeoides (Table 8) occur with quite considerable regularity, although generally as single thalli. The rapid, natural loss of branches from the trees, supplemented by branching, means that the thickets become less dense, and all the pines are deprived of their lower branches. In this way certain species which show a preference for them are eliminated, such as Bacidia chlorococca, Cetraria sepincola, Lecanora umbrina and L. conizaeoides which on 4160-year old and older pines occur only occasionally and then in very small numbers (Table 8). The number of Lecanora conizaea distinctly decrease.

On 61-80-year old pines lichens grow to a height of 3-4 m Hypo- 
gymnia physodes is absolutely dominant on most trees, Lepraria aeruginosa is also abundant, and Pseudevernia furfuracea fairly so. Lecidea scalaris and Parmeliopsis ambigua, and occasionally Cetraria glauca and Parmeliopsis aleurites are found on many trunks. These two latter species are found more often and in greater number only on pines over 80 years old.

Crustose lichens, mainly Lecanora conizaea, are commonest on the youngest pines (age classes Ia and Ib), although they become fewer in number as the trees grow. As regards cover and frequency, the trunks of older specimens of Pinus silvestris are dominated by lichens with foliose and fruticose thalli, in the first place by Hypogymnia physodes (Fig. 14).

Of the 300 specimens of Pinus silvestris studied in detail, 30 species of epiphytes (28 lichens and 2 bryophytes) were found in the various age classes (Table 8). Only half of them, at least in one class, reach

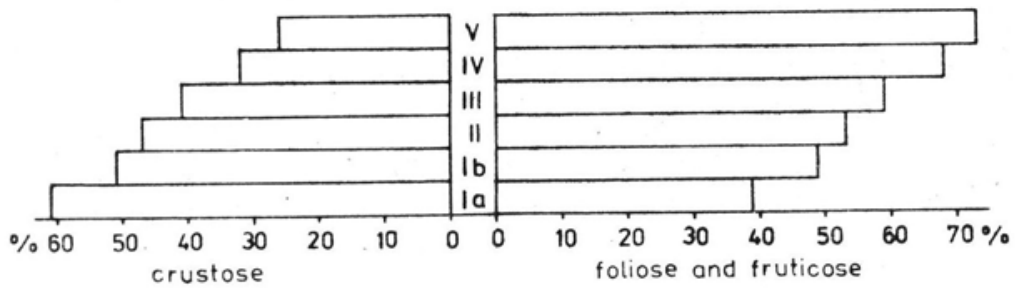

Fig. 14. Morphological forms of lichens colonizing pine logs in age classes Ia-V $(100 \%=$ sum of occurrences of all species in a given age class)

Ryc. 14. Udzial form morfologicznych porostów w zasiedlaniu pni sosen w klasach wieku Ia-V $(100 \%=$ suma wystąpień wszystkich gatunków w danej klasie wieku)

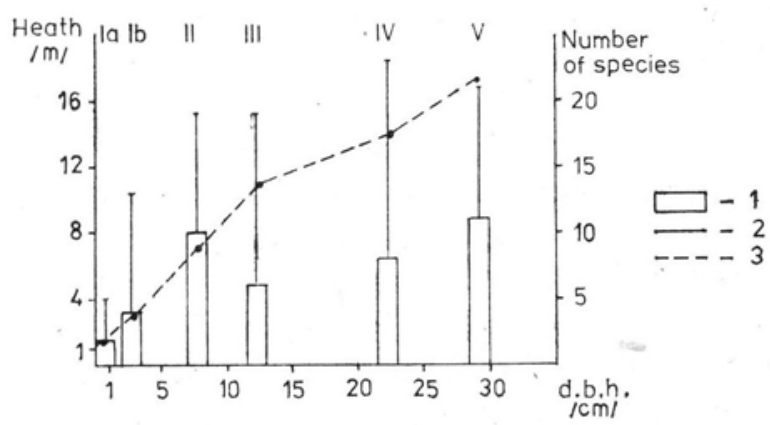

Fig. 15. Number of epiphyte species on pines in particular age classes (Ia-V) with respect to tree height and d.b.h.

1 - species with a degree of constancy of II-V, 2 - sporadic species, $3-$ tree d.b.h. and height

Ryc. 15. Liczba gatunków epifitów na sosnach w poszczególnych klasach wieku (Ia-V) na tle wysokości i pierśnicy drzew 1 - gatunki ze stopniem stałości II-V, 2 - gatunki sporadyczne, 3 - pierśnica i wysokość 
a degree of constancy of II or greater. The remainder occur sporadically, often quite accidentally. The variety of species diversifies as the pine grow (Table 8, Fig. 15).

In all, 35 species of lichens were found on Pinus silvestris in the studied area. Apart from those given in Table 8, they include Chaenotheca melanophaea, Cladonia macilenta, Cl. minor, Cl. ochrochlora, $\mathrm{Hy}-$ pogymnia tubulosa, Lecidea flexuosa and Parmelia exasperatula which, as epiphytes on Pinus silvestris, occurred occasionally.

13 species of the pine epiphytes found belong to the genus Cladonia. They grow abundantly at the base and on the lower trunks of pines, especialy older specimens. Of the remaining taxons, only 12 achieve a degree of constancy of II or greater at least in one age class. Taking this into account, one can say that the epiphytic flora of Pinus silvestris is very poor and weakly differentiated, regardless of the age of the phorophytes.

Species which are predominant in all age classes of pine, i.e. Hypogymnia physodes and Lecanora conizaea, are ubiquitous lichens, like Bacidia chlorococca, Lepraria aeruginosa and Pseudevernia furfuracea. Others, such as Cetraria glauca and C. sepincola, are more commonly found on birch bark. Only Parmeliopsis ambigua, and especially P. aleurites and Lecanora conizaeoides show a rather greater preference for pine bark.

\subsubsection{The more important epiphytic species on Pinus silvestris}

Hypogymnia physodes - occurs at all stages of growth of the trees, and starting from about 20-year old plantations is absolutely dominant on most pines. Less abundant on the lower parts of the trunk, up to $0.2-0.5 \mathrm{~m}$ from the base.

Lecanora conizaea - a pioneer species, initiating the colonization of pine bark. Occurs in great number on (5)10-20(40)-year old pines, especially on the upper surfaces of the branches. Not often found on older pines, over 40-year old. Grows on the trunk in small quantities and more often around the base, up to a height of $0.5-1.0 \mathrm{~m}$.

Bacidia chlorococca - like the previous species, occurs mainly on the upper surfaces of the branches, though far less abundantly. Occasionally found on the bark of the trunk. Often forms apothecia. Thalli are usually thickly covered with epiphytic algae.

Lepraria aeruginosa - occurs fairly abundantly, sometimes in great number, mostly in the bark fissures of older pines where the air humidity is somewhat higher.

Pseudevernia furfuracea - normally grows as single, well-formed thalli on the bark of older pines (over 30 years).

Lecidea scalaris - rarely occurs on young pines, but is almost al- 
ways present on trees over 60-year old in well-illuminated stands of dry pine forest. A xerophilous species, usually grows on the southern and western faces of the trunk, more rarely on the eastern face and only exceptionally on the northern face.

Lecanora umbrina - more often found only on 21-40-year old pines, especially on the bark of twigs or on the exposed wood of old, decaying branches. Occurs as small, single and frequently not very typically formed thalli.

Lecanora conizaeoides - grows like the previous species, but rarer.

Parmeliopsis ambigua - found occasionally on young pines up to 20-year old, with greater constancy though always in small quantities on trees over 60-year old, chiefly on the lower trunk (up to $1 \mathrm{~m}$ from the ground).

Parmeliopsis aleurites - a rare species occurring in small number on old pines in well-lit stands. As opposed to Parmeliopsis ambigua, appears to avoid the lower parts of the trunk.

Cetraria sepincola - often found, though in small quantities, on the branches of 11-30-year old pines, very rarely on the trunk bark. Not found on older pines.

Cetraria glauca - as single, small thalli found sporadically on young pines; grows more often and in greater number on pines over 80-year old in old well illuminated dry pine forests.

Cladonia spp. - occur in quite large number at the base of pine trunks, rarely reaching a height of $0.5 \mathrm{~m}$, though occasionally exceeding this. Very often grows as flakes of primary thallus difficult to identify. The commonest species include $\mathrm{Cl}$. chlorophaea, $\mathrm{Cl}$. digitata and $\mathrm{Cl}$. glauca.

\subsubsection{Discussion}

Both the epiphytic flora of Pinus silvestris and the lichen communities occurring on its bark have been studied in various regions of Europe (Schultz-Korth 1931; Klement 1955; Kershaw 1964; Barkman 1969; Malysheva et al. 1980, and others). Much information is also available from Poland about pine epiphytes. The lichen flora of pine bark has been generally characterized in many floristic and phytosociological papers (e.g. Tyszkiewiczow a 1935; Glanc 1965; Zielińska 1967; Rydzak, Sałata 1970; Cieśliński 1973; Toborowicz 1976).

In order to compile a review of lichens occurring on the bark of Pinus silvestris in the whole of Poland, the floristic data from 32 papers describing different regions of the country is compared (Table 9). A total of 125 species is listed. The vast majority of them -87 , i.e. almost $70 \%$ - were mentioned in at most six papers. A large group of these 
Frequency of occurrence of epiphytic lichens on Pinus silvestris in Poland

/based on 32 publications - for the 1ist, see under/

Częstość występowania porostów epifitycznych na Pinus silvestris w Polsce

/na podstawie 32 publikacji - wykaz pod tabela/

\begin{tabular}{|c|c|}
\hline 1 & List of species - Wykaz Eatunków \\
\hline $25-32$ & $\begin{array}{l}\text { Hypogymia physodes, Lecidea scalaris, Parmeliopsis aleurites, } \\
\text { Pseudevernia furfuracea, Usnea hirta. }\end{array}$ \\
\hline $19-24$ & $\begin{array}{l}\text { Cetraria pinastri, Chaenotheca melanophaea, Cladonia coniocraea, } \\
\text { Cl. digitata, Hypogymnia tubulosa, Iepraria spp., Parmeliopsis } \\
\text { ambiqua. }\end{array}$ \\
\hline $13-18$ & $\begin{array}{l}\text { Bacidia chlorococca, Cetraria chlorophylla, C. Glauca, Clacionia } \\
\text { macilenta, Evernia prunastri, Lecanora varia. }\end{array}$ \\
\hline $7-12$ & $\begin{array}{l}\text { Bryopogon crispus, B. fuscescens, B. implexus, B. subcanus, Cet- } \\
\text { raria sepincola, Chaenotheca chry socephala, Ciadonia baciliaris, } \\
\text { Cl. cenotea, Cl. chlorophaea, Cl. Glauca, Evernía mesomorpha, } \\
\text { Lecanora chlarona, L. conizaea, L. conizaeoides, L. pinastri, } \\
\text { Lecidea flexuosa, L. symmicta, Parmelia caperata, P. fuliginosa, } \\
\text { P. sulcata, Usnea dasypoga. }\end{array}$ \\
\hline $1-6$ & 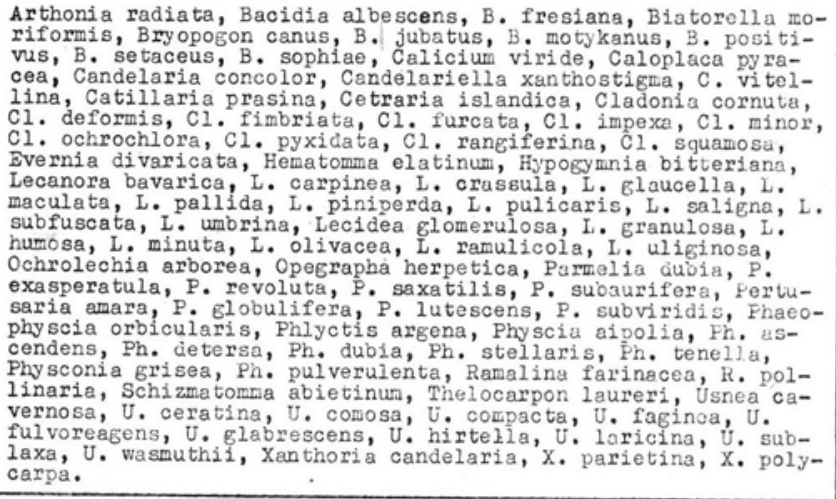 \\
\hline
\end{tabular}

1 - number of publications in which given species of lichens were mentioned: 1 - liczba publikacji, w których wymieniono dane gatunki porostów:

After /Wedrug/: Sulma /1935/, Tobolewski /1952, 1958/, Rydzak /1955, 1961, 1969a, b, 1970/, Halicz /1959/, Nowak /1961, 1967/, Dziabaszewski 1962a, b/, Fabiszewski /1964/, Kiszka /1964, 1979/, Glanc /1965/, Zielińska /1967/, Rydzak, Salata /1970/, Glanc et al. /1971/, Bystrek, Bystrek /1972/,

Cieślinskí 1973, 1978/, Orâyczynska /1973/, Warmínska /1973/, Bystrék, Ożóg

/1974/, Czyzewska /1974/, Nowotarska /1976/, Toborowicz /1976/, Paztynowicz
/1982 /, Budzbon /unpbl.'.

sporadic species consist of nitrophilous and coniophilous lichens, e.g. from the genera Physcia s.l., Xanthoria, Ramalina and Candelariella; also included in this group are plants which are very rare in Poland, e.g. from the genera Bryopogon and Usnea.

Only 12 species (see Table 9) are given in 19 or more papers. Most of these are common and ubiquitous species.

The number of lichen species found on pines in various regions of Poland ranges from 9 (Trębaczew reserve - C zyżewska 1974) to 49 (Roztocze - R y d z a k 1969b). Most papers mention from 15 to 30 species of epiphytes. Similar differences occur in papers from various European countries, e.g. 17 species from Holland are mentioned (B a r kman 1969), 29 from the Tatar ASSR (M a lysheva et al. 1980), 36 from northern Switzerland (O chsner 1928) and 51 from Brandenburg in Germany (Schulz-Korth 1931). 
Much less information can be gleaned from the literature about the changes which take place in the epiphytic flora of pines during the growth of the trees ( $\mathrm{Halicz} 1959 ; \mathrm{K} \mathrm{er} \mathrm{shaw} 1964 ; \mathrm{K}$ is z k a 1964; Barkman 1969; Bystrek, Bystrek 1972; Cieśliński 1973; $\mathrm{H}$ a le 1974). All the authors mentioned here agree that the number of epiphyte species and their cover increase with the age of the tree. However, Barkman's statement (1969), that greater numbers of foliose and fruticose lichens than crustose lichens are found on younger trees, cannot apply to pines. The author's own research (see Fig. 14) and his observations of pine epiphytes in other parts of northern Poland lead to the diametrically opposite conclusion. It has further to be emphasised that the presence of morphological forms in the epiphytic flora depends not only on the species of tree but also on the habitat conditions in which the phorophyte is growing.

Kiszka (1964), and Bystrek and Bystrek (1972) include some information about epiphyte succession on pines during their growth. In these two papers, the species mentioned as initiating the colonization of pine bark and those dominating on old trees are the same as in the north-western Bory Tucholskie. Differences exist only in the presence or absence of species playing a quantitatively minor part in the epiphytic flora of Pinus silvestris.

\subsubsection{LICHENS OF DECAYING PINE STUMPS}

The large-scale felling practised in the majority of Polish forests leads to the exposure of extensive tracts several hectares in area and to the creation of new, specific habitats for plants and animals: the stumps of felled trees. Because of the lack of heavy equipment for stump-pulling and because manual stump-pulling is an arduous and time-consuming operation, the stumps are generally left in the cutting area where, exposed to the actions of the atmosphere, microorganisms, animals, fungi and plants, they gradually decompose.

There exists a lot of information about the various groups of plants, animals and microorganisms which colonize stumps and cause their decay. On the other hand, there are few papers in which their authors devote any attention to epixylic lichens. A review of the older literature on this subject, especially from Scandinavia, is provided by A h t i (1977). In recent years, the succession of lichens on decaying stumps has been described by Muhle and LeBlanc (1975) and Lambert and M a y c c k (1968) from Canada, by Frey (1959) from Switzerland and Lündström (1970) from Sweden. Henningsson and L ündström (1970) described the effect of substances produced by lichens on fungi destroying wood. Many floristic and phytosociological papers mention lichen species and plants growing on decaying 
wood. Rather more has been written about the succession of bryophytes in this habitat. A review of this work is given by $\mathrm{Muhle}$ and $\mathrm{Le}$ Blanc (1975) and A hti (1977). In some of these papers, the authors also mention lichen species participating in communities of mosses and liverworts in the various stages of succession on tree stumps.

Decaying wood has in a few cases been one of the main topics of interest in the Polish botanical and zoological literature. W i a c k ow$\mathrm{ski}$ (1957) described the succession of entomofauna on pine stumps in various coniferous forest habitats. The succession of liverworts on stumps is fairly well understood (R e y ment-Grochow ska 1950b; Szweykowski 1953; Berdowski 1974). Grzywacz (1976), and Rykowski and Sierota (1972) make reference to the fungi which decompose pine wood in a dry pine forest habitat. Many lichen species from decaying wood, particularly from stumps of felled trees, are mentioned in floristic papers by Tobolewski $(1955,1958)$, Glanc and Tobolewski (1960), Dziabaszewski (1962a), Kiszka (1967a, b), C i éśliński (1973), Nowotarska (1976) and others. However, the succession of lichens in this habitat is referred to only in a few papers, e.g. K is z k a (1964), O le ch (1973), K o z ik (1977).

\subsubsection{Method}

The study was carried out in a Cladonia-pine forest habitat. The objects of study were pine stumps remaining after the trees had been felled in the course of normal forest management. The stumps were divided into five classes, according to the time which had elapsed since the trees were cut down: I $-1-5$ years, II $-6-10$, III $-11-15$, IV 16-20, V - 21-30. 34 stumps in each class were analysed, i.e. a total of 170. All the plant species found on each stump were listed. At the

$$
\text { Table } 10 \text { - Tabela } 10
$$

Scale of plant cover on decaying stumps

Skala pokrywania roślin na murszejących pniakach

\begin{tabular}{|c|c|c|}
\hline $\begin{array}{c}\text { Degree of } \\
\text { scale } \\
\text { Stopień skali }\end{array}$ & $\begin{array}{c}\text { Range (in \%) } \\
\text { Zakres (w \%) }\end{array}$ & $\begin{array}{c}\text { Mean (in \%) } \\
\text { Srednia (w \%) }\end{array}$ \\
\hline 1 & to 1.0 & 0.5 \\
2 & $1.1-5.0$ & 3.0 \\
3 & $5.1-25.0$ & 15.0 \\
4 & $25.1-50.0$ & 37.5 \\
5 & $50.1-100.0$ & 75.0 \\
\hline
\end{tabular}


same time their cover on the sides of the stump and on the stump surface were noted separately. The cover was assessed on a five-point scale (Table 10). The circumference and height of the stumps were measured, and the loss of wood through decay as a percentage of the original circumference was estimated. In the field stumps were chosen at random, although any which had suffered mechanical damage, e.g. from wild boars feeding in the area, were avoided.

The coefficients of similarity between the flora of the stump surface and sides were calculated according to the formula given by $\mathrm{P}$ a w $10 \mathrm{w}-$ s k i (1972) after Kulczyński (1940):

$$
\mathbf{P}=\frac{100}{2}\left(\frac{\mathrm{c}}{a}+\frac{\mathrm{c}}{b}\right)
$$

where: $a$ is the number of species growing on the sides, $b$ is the number of species growing on the stump surface, and $c$ is the number of species common to both surfaces.

\subsubsection{The process of decay in pine stumps}

Pine wood contains 50-60\% cellulose, 27-29\% lignine, about $12 \%$ pentozamines, $5.5-12.5 \%$ resins, waxes and fats, and $0.3-0.5 \%$ mineral substances (Glixelli, Prosiński 1951; Prosiński 1969; Surmiński 1970). It consists of sapwood and heartwood. The sapwood makes up the outer layer of the trunk, on average up to $1 / 3$ of the radius. This wood contains fewer resinous substances, waxes and fats (about $5.5 \%$ ) than the heartwood (about $12 \%$ ), and is more acid.

Many chemical changes take place in the wood of pine stumps during the decay process. The amount of cellulose falls and the acidity rises in the sapwood. Fungal activity during the first five years causes the sugar content to rise; after this period, however, this content decreases rapidly. The greatest qualitative changes in the chemical composition of the sapwood take place between the 5th and 7th year after felling (W i ą c k o w sk i 1957).

The decay process of a pine stump in a dry pine forest habitat starts with the bark falling off. 6 to 10-year old stumps are mostly devoid of bark, although in a few cases it may remain on the stump for something over 10 years. After this the sapwood begins to decompose; it is less resistant than the heartwood, among others, because it contains less than half as much resin. Table 11 shows the loss of wood during the period of decay, also the changes in circumference and height of the pine stumps.

On 6-10-year old stumps the losses due to decay are yet minimal and increase only slightly in stumps 11-15-year old. The rate of decay however rises considerably during the following years (Table 11). The 
period of resistance of pine wood given in the literature is from 8 to 12 years (S u r miński 1970 after Krzysik 1957). As compared to this, decay takes place more slowly in the studied area. One cannot exclude the possibility that this delay is caused by lichens - more precisely, by substances produced in their thalli (e.g. usnic acid), which inhibit the growth and activity of many bacteria and fungi, including those decomposing cellulose (M a licki 1965, 1967, 1970; Hennings on, L ündström 1970), and which restrict the germination and development of higher plants (e.g. Fabiszewski 1975; R a maut, Corvisier 1975; Vainshtein, Tolpysheva 1975).

In the studied area, decomposition of pine stumps is complete after about $30-40$ years.

$$
\text { Table } 11 \text { - Tabela } 11
$$

Dimensions of the pine stumps studied and their degree of decay in different age

Rozmiary badanych pniaków sosnowych oraz stopień ich zmurszenia w różnym wieku

\begin{tabular}{|c|c|c|c|c|c|}
\hline \multirow{2}{*}{$\begin{array}{c}\text { Age of } \\
\text { stumps } \\
\text { Wiek } \\
\text { pniaków }\end{array}$} & \multicolumn{2}{|c|}{$\begin{array}{c}\text { Circumference (in cm) } \\
\text { Obwód (w cm) }\end{array}$} & \multicolumn{2}{|c|}{$\begin{array}{c}\text { Hight (in cm) } \\
\text { Wysokość (w cm) }\end{array}$} & \multirow{2}{*}{$\begin{array}{l}\text { Circumference } \\
\text { losses (in \%) } \\
\text { Ubytki obwodu } \\
\text { (w \%) }\end{array}$} \\
\hline & $\begin{array}{l}\text { mean } \\
\text { średni }\end{array}$ & $\begin{array}{l}\text { range } \\
\text { zakres }\end{array}$ & $\begin{array}{l}\text { mean } \\
\text { średnia }\end{array}$ & $\begin{array}{l}\text { range } \\
\text { zakres }\end{array}$ & \\
\hline I & 113 & $62-204$ & 10 & $1-34$ & 0.5 \\
\hline II & 124 & $78-187$ & 14 & $3-38$ & 3 \\
\hline III & 108 & $57-200$ & 14 & $2-34$ & 16 \\
\hline IV & 81 & $37-136$ & 14 & $0-35$ & 43 \\
\hline V & 58 & $25-108$ & 13 & $0-31$ & 64 \\
\hline
\end{tabular}

\subsubsection{The flora of decaying pine stumps}

In the studied area, lichens predominate at all stages of the succession on pine stumps (Figs. 16, 17, Tables 12, 13); of the total of 51 species found on stump surfaces, 39 are lichens. In the flora of the stump sides these figures are 58 and 45 respectively. As a rule, lichens cover most of the stump; only on older, much decayed stumps in shaded pine boskets and thickets are bryophytes of greater importance. Here, the lichen cover reaches $10 \%$ on the stump surfaces and $20 \%$ on the sides. Vascular plants occur sporadically and singly.

Except for Cladonia botrytes, there are no characteristic species exclusive to decaying stumps as a habitat for lichens. Most of the remaining species lead on optimum existence on the ground or on tree bark. Only a small group of species prefers decaying wood and is found there more often than in other habitats; they include Lecidea humosa, Cladonia cenotea, $\mathrm{Cl}$. floerkeana, $\mathrm{Cl}$. digitata and $\mathrm{Cl}$. macilenta.

The analysis of the floristic composition of the stump surface and sides reveals quite large qualitative and quantitative differences between 
Table 12 - Tabela 12

The constancy coefficient and average percentage cover of species

on stump surface with respect to the age of the stumps

Stałość 1 srednie pokrywanie / w \%/ gatunków na powierzchniach ciecla

w zaleznosci od wieku pniakow

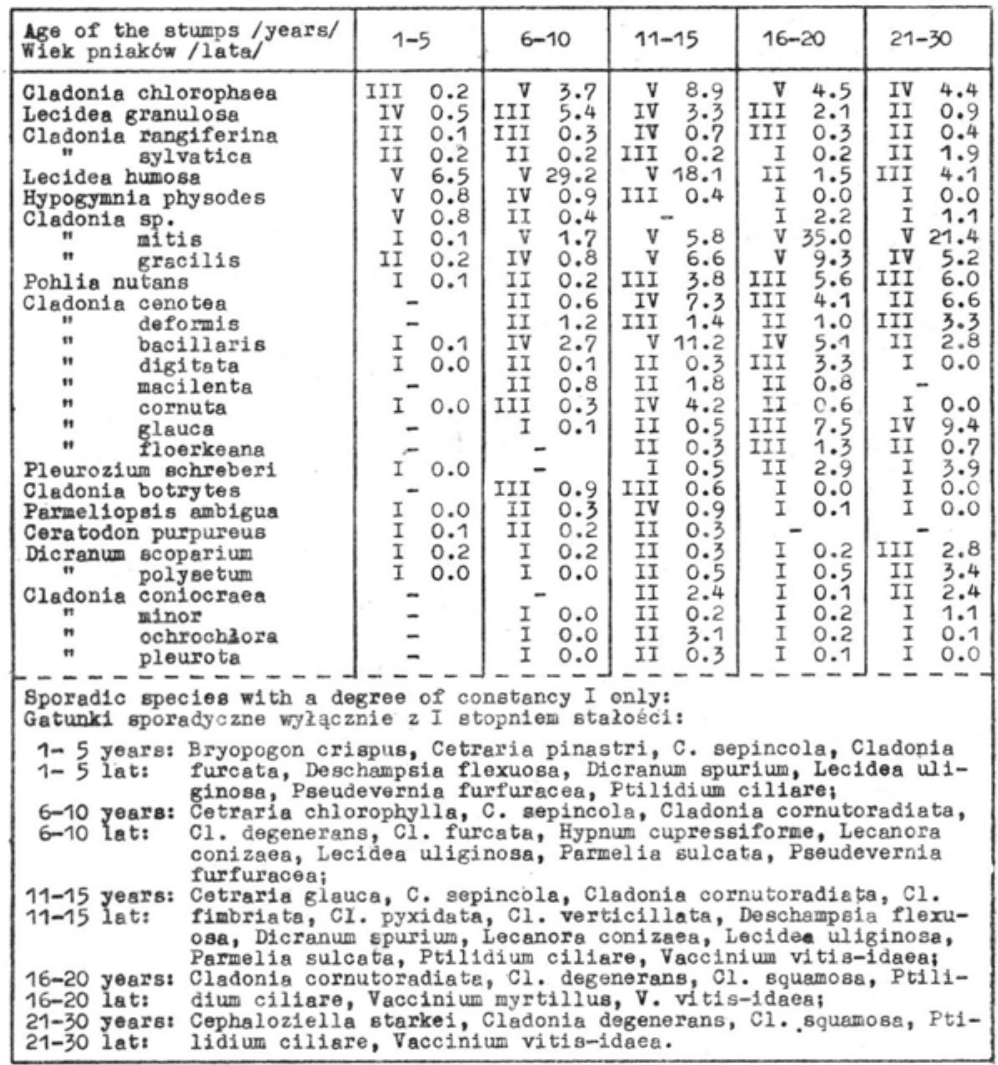

them. The species distinguishing the stump surface include (in descending order of frequency) Cladonia mitis, Cl. gracilis, Lecidea humosa, Cladonia rangiferina, $\mathrm{Cl}$. cenotea, $\mathrm{Cl}$. cornuta, Cl. sylvatica, $\mathrm{Cl}$. botrytes, $\mathrm{Cl}$. floerkeana and $\mathrm{Cl}$. pleurota. Species exclusive to the sides are Lecidea scalaris and Lepraria aeruginosa. The following species distinctly prefer the sides: Pohlia nutans, Cladonia digitata, Dicranum polysetum, D. scoparium, Parmeliopsis ambigua, Pleurozium schreberi, Cladonia cornutoradiata and Lecanora conizaea.

The correlations between the flora of the stump sides and surfaces are defined by the coefficients of similarity (Fig. 18). The sides and surfaces of 1-5-year old stumps show the lowest floristic similarity $(50 \%)$. This is because, among other things, the sides are still largely covered with bark on which species growing at the trunk base have remained, while the succession process has only just started on the stump surface. 
Table 13 - Tabela 13

The constancy coefficient and average percentage cover of species

on stump sides with respect to the age of the stumps

Stałosć 1 średnie pokrywanie /w \%/ gatunków na sciankach w zaleźnosoi od wieku pniaków

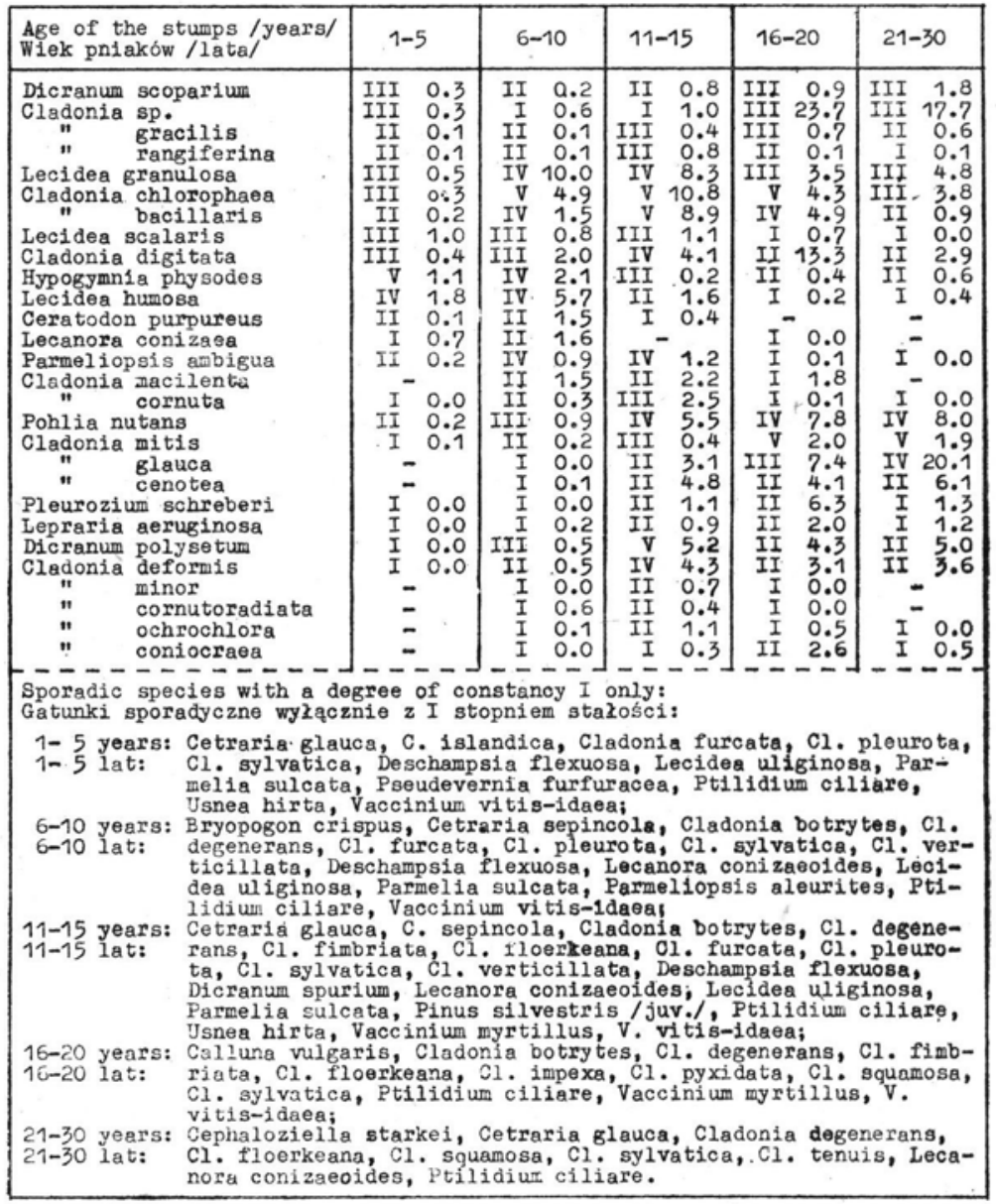

The highest average coefficients of similarity (over $60 \%$ ) and their least deviations were given by the stages of succession on 11-15- and 16-20year old stumps. This results from the fact that the habitat conditions obtaining on the stump surfaces and sides have become more alike: the sides have usually lost their bark and, just as on the stump surface, the wood there has already decayed somewhat.

The more interesting taxons found on pine stumps include Cladonia botrytes (48 occurrences), Bryopogon crispus and Usnea hirta (2 each), and Cetraria islandica and C. pinastri (1 each). 


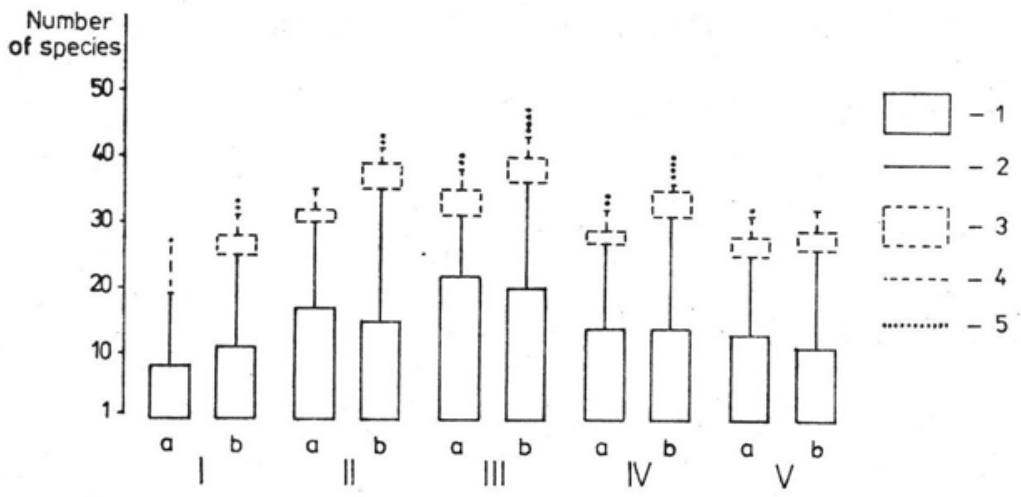

Fig. 16. Number of species colonizing the surfaces (a) and sides (b) of pine stumps in different age (I-V)

1 - lichens with a degree of constancy of II-V, 2 - sporadic lichens, 3 - bryophyte with

a degree of constancy of II-V, 4 - sporadic bryophytes, 5 - sporadic vascular plants

Ryc. 16. Liczba gatunków zasiedlających powierzchnie cięcia (a) i ścianki (b) pniaków sosnowych w różnym wieku (I-V)

1 - porosty ze stopniem stałości II-V, 2 - porosty sporadyczne, 3 - mszaki ze stopniem stałości II-V, 4 - mszaki sporadyczne, 5 - rośliny naczyniowe sporadyczne

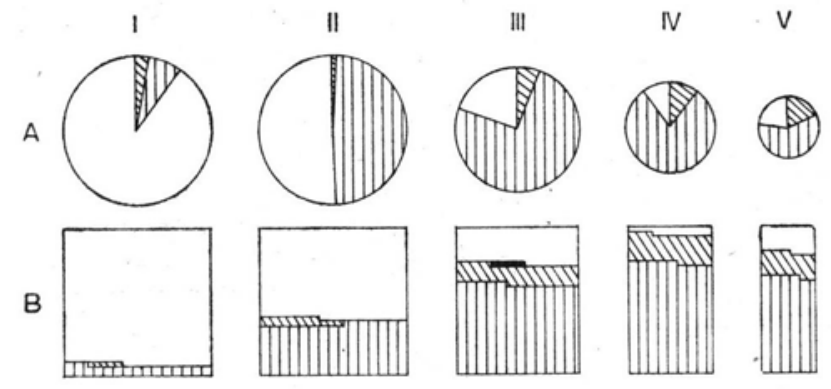

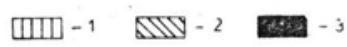

Fig. 17. Percentage changes in the cover of the surfaces (A) and sides (B) of decaying pine stumps in different age (I-V). The reduction in diameter of circles and square sides is proportional to wood losses.

1 - lichens, 2 - bryophytes, 3 - vascular plants

Ryc. 17. Zmiany pokrywania (w \%) powierzchni cięcia (A) i ścianek (B) murszejących pniaków sosnowych w różnym wieku (I-V). Zmniejszanie się średnic kół i boków kwadratów jest proporcjonalne do ubytków drewna

1 - porosty, 2 - mszaki, 3 - rosliny náczyniowe

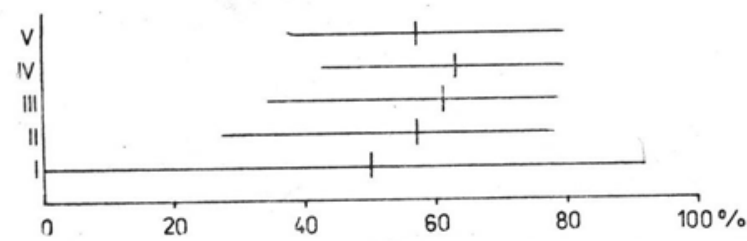

Fig. 18. Ranges and mean values of coefficients of floristic similarity of surfaces and sides of decaying pine stumps in different age (I-V)

Ryc. 18. Zakresy i wartości średnie współczynników podobieństwa florystycznego powierzchni cięcia i ścianek murszejących pniaków sosnowych w różnym wieku (I-V) 


\subsubsection{The succession on decaying pine stumps}

The drastic change in habitat conditions resulting from the removal of the tree stand (see chapter 3.2.) means that in the cutting area, the animal and plant species of the forest substantially reduce their abundance and vitality, or perish, and that there appears a numerous group of eurytopic and heliophilous forms. This applies to both the terricolous flora and the plants colonizing the stumps.

Three or four years after felling, one can find on the pine stump surfaces many tiny patches of Hypogymnia physodes a few millimetres long, thalli of Lecidea humosa, and in smaller numbers Lecidea granulosa, single podetia of Cladonia bacillaris, Cl. chlorophaea, Cl. gracilis, $\mathrm{Cl}$. mitis and $\mathrm{Cl}$. sylvatica. Furthermore, one comes across small concentrations of crustose and flaky primary thalli of the above-mentioned species, along with other Cladonia species difficult to identify (Table 12). Of the bryophytes, the protonema and a few stalklets of Ceratodon purpureus, Dicranum scoparium and Pohlia nutans can be found. Some
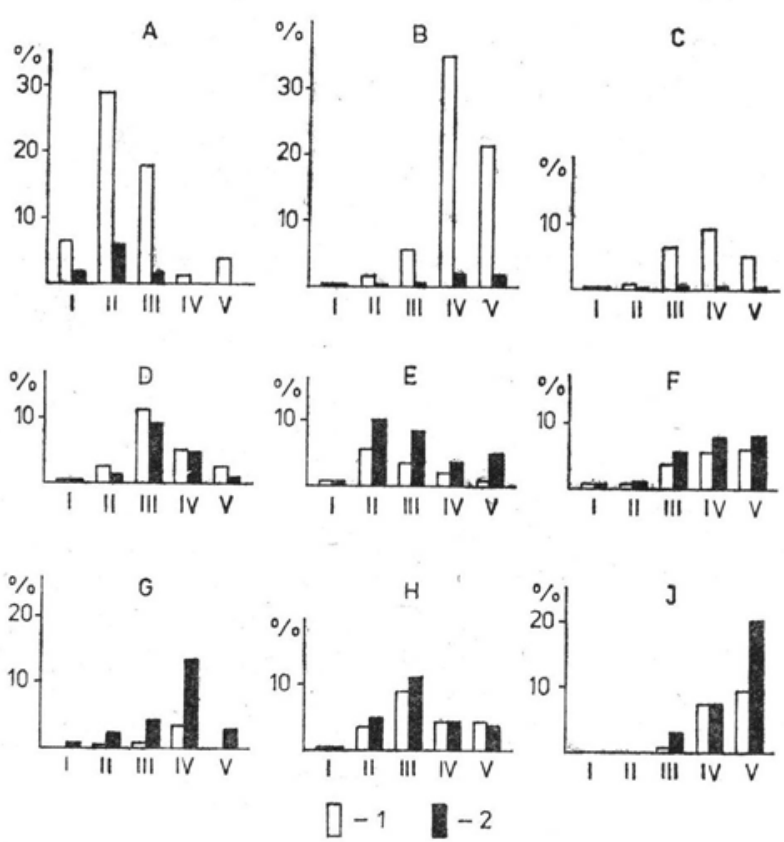

Fig. 19. Average cover of selected species on decaying pine stumps in different age (I-V)

1 - stump surface, 2 - stump sides

Ryc. 19. Srednie pokrywanie wybranych gatunków na murszejących pniakach sosnowych w różnym wieku (I-V)

1 - powierzchnie cięcia, 2 - scianki

A - Lecidea humosa, B - Cladonia mitis, C - Cl. gracilis, D - Cl. bacillaris, E - Lecidea granulosa, F - Pohlia nutans, G - Cladonia digitata, H - Cl. chlorophaea, $\mathrm{J}-\mathrm{Cl}$. glauca 
of these species were found both on the bark and in its fissures on the stump sides.

The plant cover of 3-5-year old stumps is minimal, on average from: $7.7 \%$ (sides) to $10 \%$ (stump surfaces). The commonest species is Lecidea humosa (Fig. 19A).

The colonizations of pine stumps by lichens is probably started by fragments of thalli carried there by the wind or lodged in 'the bark fissures (Cladia), also by soredia (e.g. Hypogymnia physodes and Parmeliopsis ambigua).

The overgrowth of the stump surface starts at the circumference and progresses towards the centre. The first species appear on the sapwood, at the edge of the stump surface. It often happens that thalli of Hypogymnia physodes and Parmeliopsis ambigua grow beyond the edge of the stump, bend over, and continue their growth on the surface. The centres of all 3-5-year old stumps, and most 6-10-year old ones still devoid of all vegetation (Fig. 20). Colonization here is probably inhibited

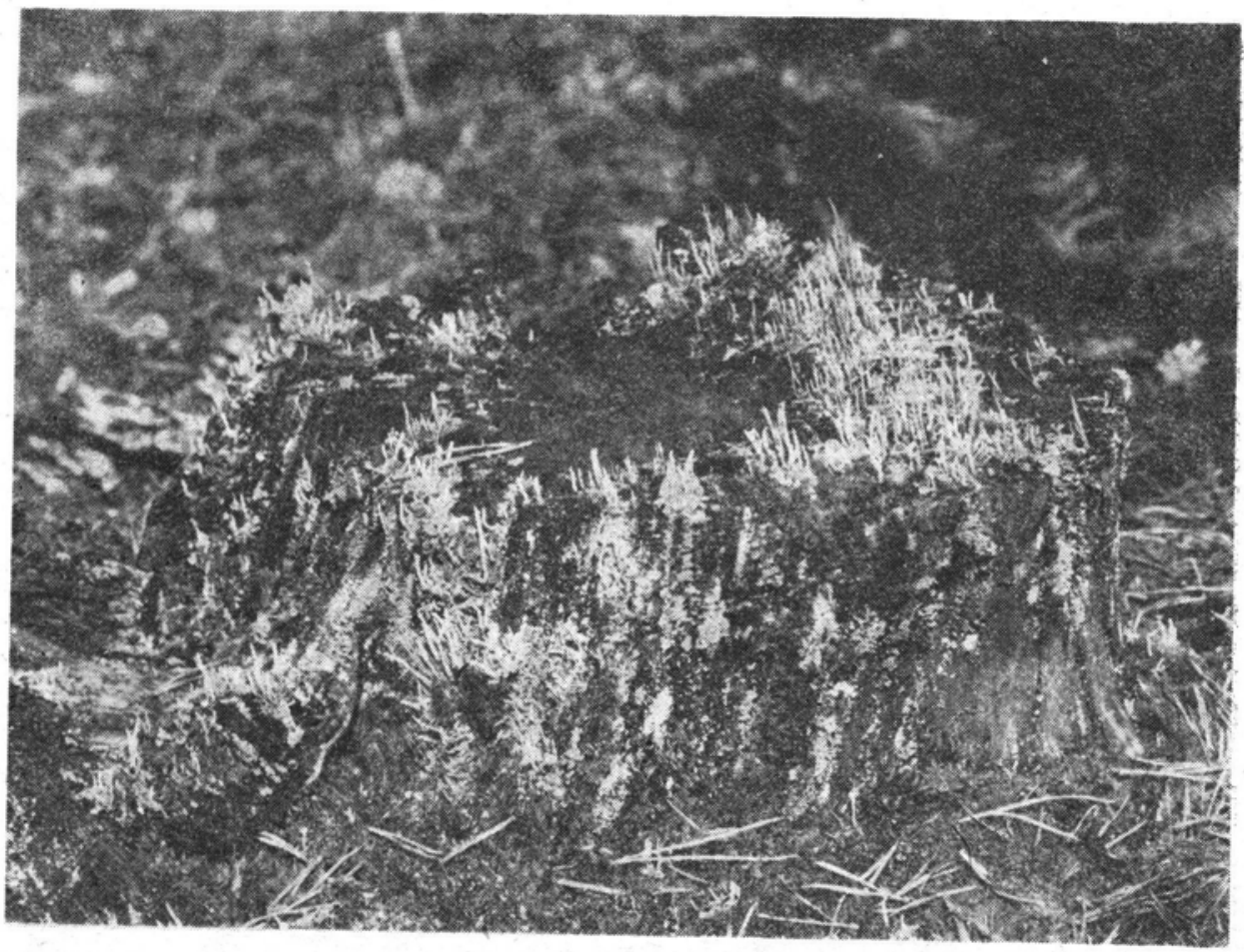

Fig. 20. 10-year old pine stump: the centre of the surface is not overgrown, Lecidea humosa, Cladonia bacillaris, $\mathrm{Cl}$. gracilis and $\mathrm{Cl}$. chlorophaea are dominant around the circumference (Photo J. Herbich)

Ryc. 20. 10-letni pniak sosnowy: środek powierzchni cięcia nie porośnięty, na obwodzie dominują Lecidea humosa, Cladonia bacillaris, $\mathrm{Cl}$. gracilis i $\mathrm{Cl}$. chlorophaea (fot. J. Herbich) 
by the resinous substances, contained in greater quantity in the heartwood than in the sapwood, and by the higher $\mathrm{pH}$ at the centre of the stumps (see Surmiński 1970; Brodo 1973).

The overgrowth of the surface intensifies 6 to 10 years after felling; the average plant cover increases to $51 \%$ (Fig. 17A). The rate of colonization of the sides is much slower and at this period starts practically from zero, as the species growing on the bark fall off with it, exposing bare wood not covered by any plants. At this stage, the species dominating the sides and surface of the stumps are Lecidea humosa and L. granulosa (Figs. 19A, E, 21); Cladonia chlorophaea and Cl. bacillaris (Figs. 19D, H) are also quite numerous here. Hypogymnia physodes and Ceratodon purpureus attain their optimum growth and cover, as also does Cladonia botrytes, a species closely associated with decaying wood (Tobolewski, Kupczyk 1976).

10-20-year old boskets constitute a transition stage between the nonforest community of pine plantations, and the forest community of 20year old and older boskets (see 7.1.1.). The greatest abundance of species in comparison with the remaining age groups and the coexistence of

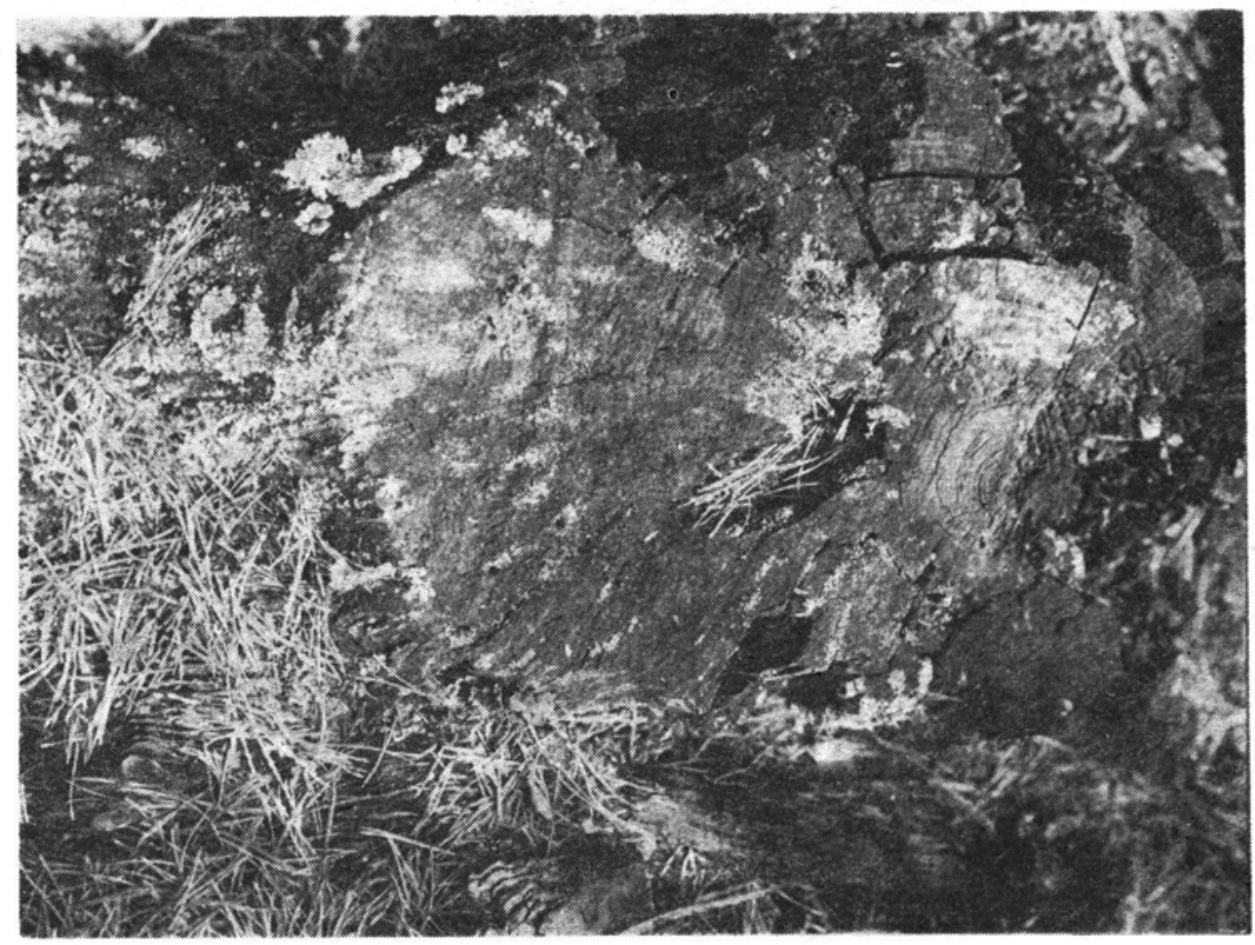

Fig. 21. 10-year old pine stump: light thalli of Lecidea granulosa are visible on the surface (Photo J. Herbich)

Ryc. 21. 10-letni pniak sosnowy: na powierzchni cięcia widoczne są jasne plechy Lecidea granulosa (fot. J. Herbich) 


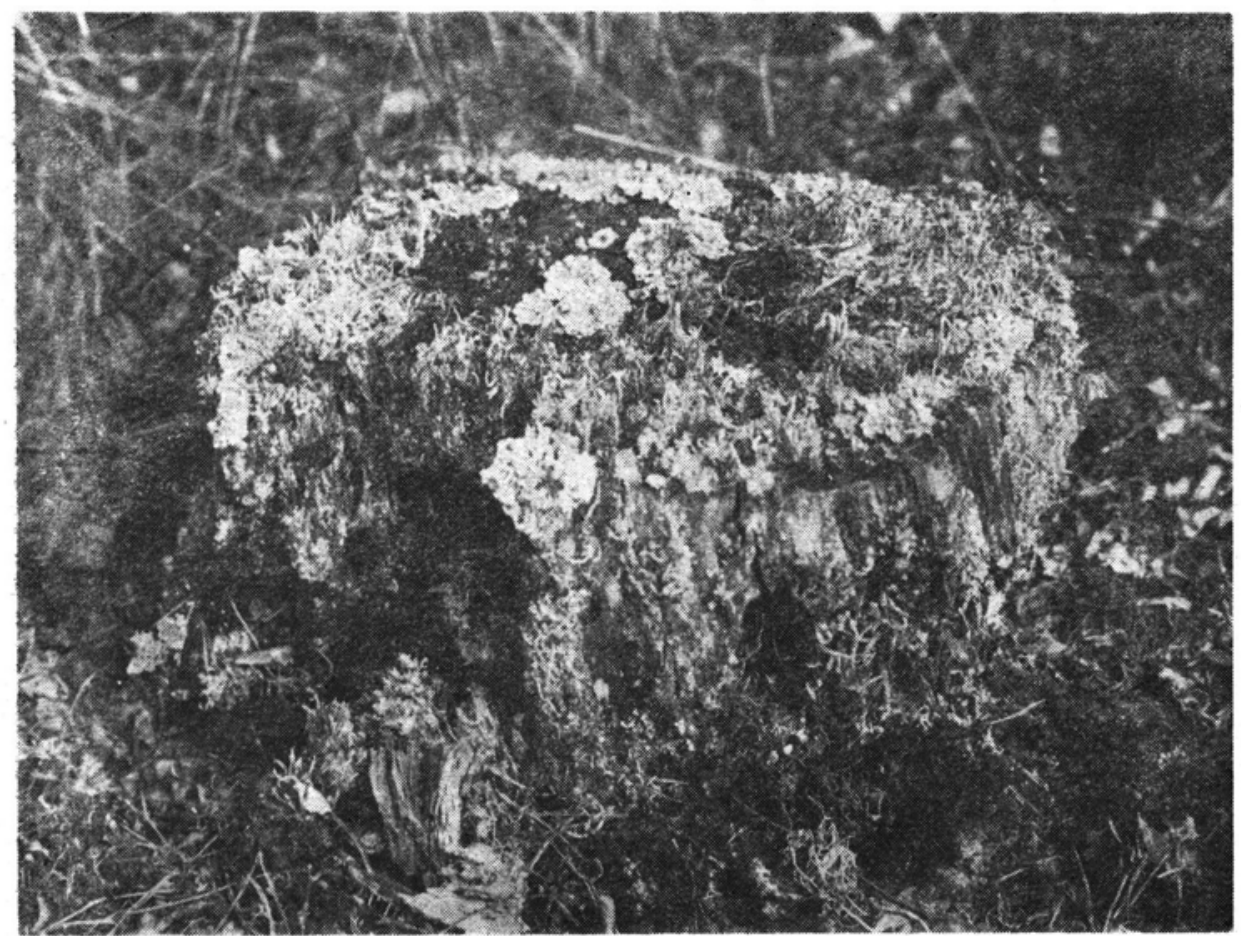

Fig. 22. Decaying pine stump at the stage of greatest differentiation of epixylic flora; Lecidea humosa, Hypogymnia physodes, Cladonia bacillaris, Cl. mitis and Cl. glauca are dominant (Photo J. Herbich)

Ryc. 22. Murszejący pniak sosnowy na etapie największego zróżnicowania flory epiksylicznej; dominują Lecidea humosa, Hypogymnia physodes, Cladonia bacillaris, Cl. mitis i Cl. glauca (fot. J. Herbich)

forest and non-forest forms are evidence for the transitional nature of these systems. The flora of 11-15-year old pine stumps shows similar features (Figs. 16, 22, Tables 12, 13). The species with the most extensive cover on the stump surfaces is still Lecidea humosa, although it is now far less numerous than on younger stumps (Fig. 19A). Heliophilous plants attain their maximum cover here: these include Cladonia bacillaris (Fig. 19D), Cl. macilenta and $\mathrm{Cl}$. ochrochlora; also eurytopic species like Cladonia chlorophaea (Fig. $19 \mathrm{H}$ ) and $\mathrm{Cl}$. cornuta, however, find optimum conditions for growth in unshaded spots. At the same time, forest species such as Cladonia gracilis (Fig. 19C), Dicranum polysetum and Pohlia nutans (Fig. 19F) appear in greater quantities and with considerable constancy on the stump sides and surfaces. Among the dominant species one also finds lichens characteristic of decaying wood Cladonia cenotea, Cl. digitata and Cl. glauca (Figs. 19G, J, 23). A distinquishing feature of this stage of the succession is, furthermore, the small number of sporadic species in relation to the overall number of species found on stumps in this age (Fig. 16, Tables 12, 13). 
A

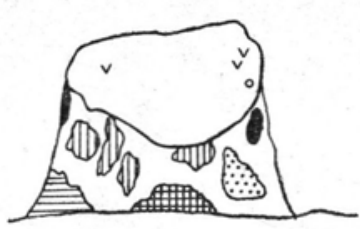

B

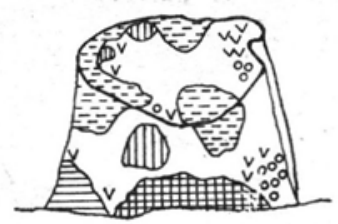

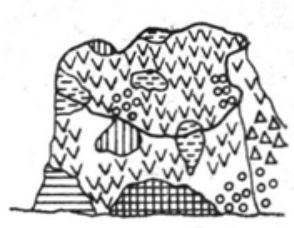

D

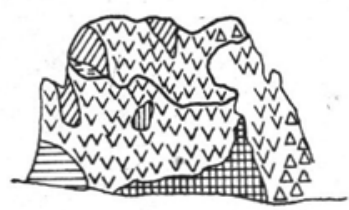

E

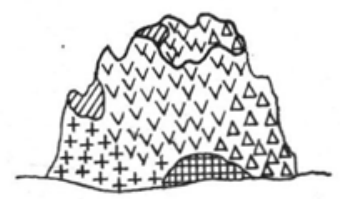

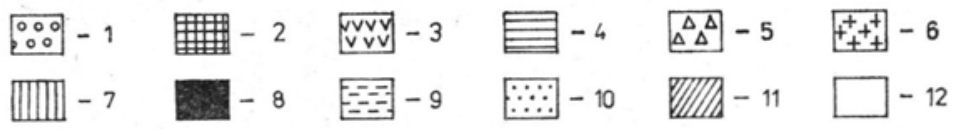

Fig. 23. Stages of succession on pine stumps

Age of stumps: A - up to $4(5)$ years, B $-5-10$ years, C $-11-15$ years, D $-16-20(25)$ years, $\mathrm{E}$ - over 20 years

1 - Ceratodon purpureus, 2 - Cladonia digitata, 3 - Cladonia spp., 4 - Dicranum scoparium, 5 - D. polysetum, 6 - Pleurozium schreberi, 7 - Hypogymnia physodes, 8 - Lecanora conizaea, 9 - Lecidea humosa, $10-$ L. scalaris, 11 - Pohlia nutans, 12 - wood not grown over

Ryc. 23. Etapy sukcesji na pniakach sosnowych

Wiek pniaków: A - do 4(5) lat, B - 5-10 lat, C - 11-15 lat, D - 16-20(25) lat, E - powyżej 20 lat

1 - Ceratodon purpureus, 2 - Cladonia digitata, 3 - Cladonia spp., 4 - Dicranum scoparium, 5 - D. polysetum, 6 - Pleurozium schreberi, 7 - Hypogymnia physodes, 8 - Lecanora conizaea, 9 - Lecidea humosa, 10 - L. scalaris, 11 - Pohlia nutans, 12 - drewno nie porośnięte

When the pines form a canopy, the stumps find themselves in shade. Most of the heliophilous species, such as Lecidea humosa, L. granulosa, Cladonia bacillaris, $\mathrm{Cl}$. botrytes, $\mathrm{Cl}$. cornuta, Cl. ochrochlora, Ceratodon purpureus and others substantially reduce their cover or perish. The second reason for the disappearance of the above-mentioned plants, and also of the foliose lichens Hypogymnia physodes and Parmeliopsis ambigua, is competition from fruticose species of genus Cladonia, and from bryophytes, whose annual growth far exceeds that of lichens ( $\mathrm{Di}$ cranum polysetum and Pleurozium schreberi). Of the fruticose lichens, the most aggressive in this competition appears to be Cladonia mitis, whose branching, relatively fast-growing podetia (see Scotter 1963) shade and stifle both the crustose thalli of Lecidea and the tiny podetia of other Cladonia.

The plant cover reaches its maximum on 16-20-year old stumps (Figs. 


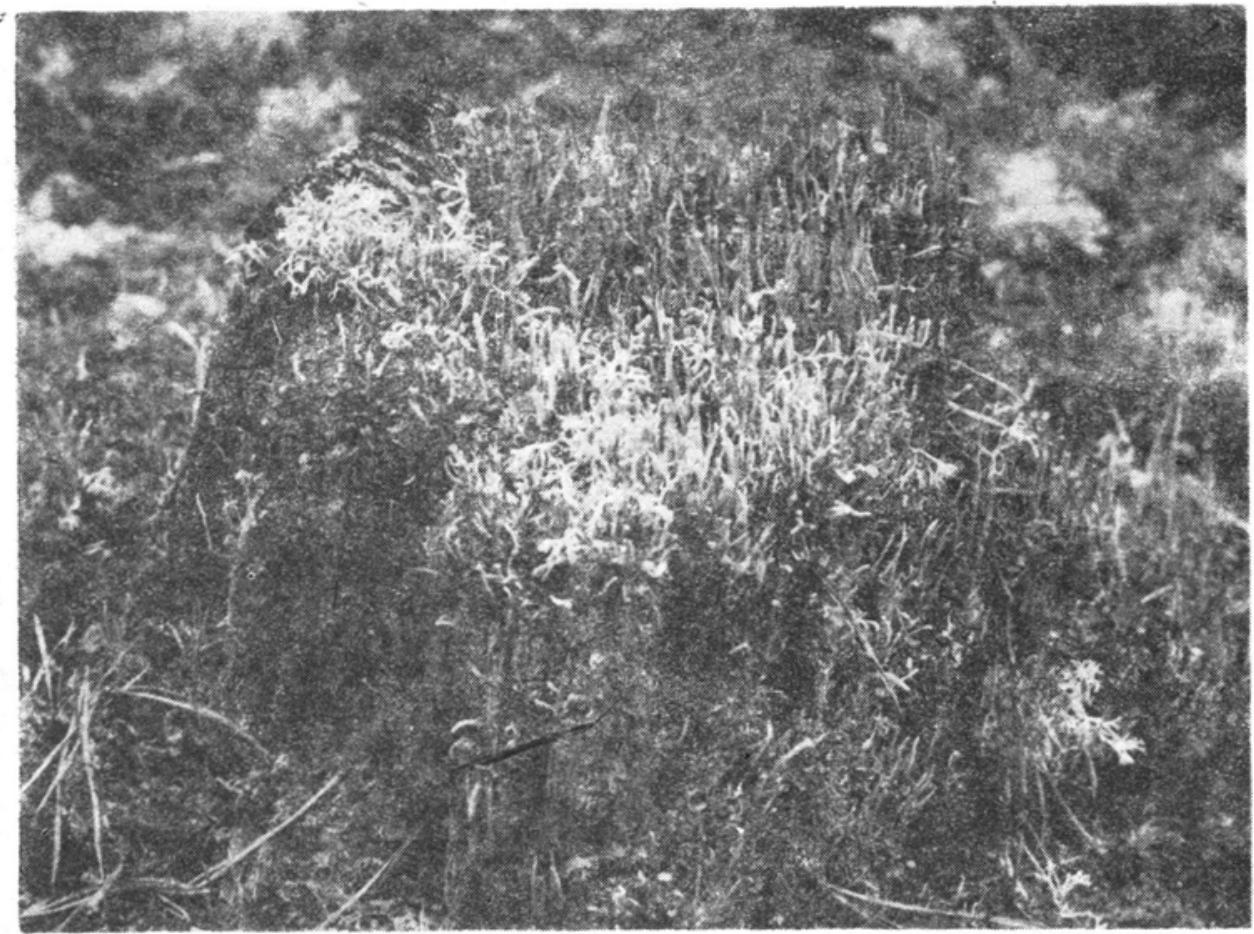

Fig. 24. 20-year old pine stump with Cladonia mitis, $\mathrm{Cl}$. gracilis and $\mathrm{Cl}$. glauca dominant on the surface (Photo J. Herbich)

Ryc. 24. 20-letni pniak sosnowy $\mathrm{z}$ dominującymi na powierzchni cięcia Cladonia mitis, Cl. gracilis i Cl. glauca (fot. J. Herbich)

$17 \mathrm{~A}, \mathrm{~B}, 23 \mathrm{D}, 24)$, but the overall and average number of species found there decreases (Fig. 16). On this stumps, the differences between the flora of the stump surface and that of the sides are smallest (Fig. 18), although quite different species predominate in the two microhabitats. The most abundant lichen on the stump surface is Cladonia mitis (Fig. 19B); also numerous are $\mathrm{Cl}$. gracilis, Cl. bacillaris, Cl. chlorophaea, $\mathrm{Cl}$. glauca and Pohlia nutans. Humusphilous species of lichens and bryophytes predominate on the decaying stump sides. These include Cladonia digitata, Cl. glauca, Cl. cenotea, Dicranum polysetum and Pleurozium schreberi; they make up for over $2 / 3$ of the overall cover of the sides (Figs. 19C, D, F, G, H, J). Cladonia glauca and Cl cenotea most frequently occur as practically indistinguishable flakes of primary thalli.

21-30-year old stumps are already largely decomposed (Table 11, Fig. 23E). The overall and average number of species (Fig. 16) is now much reduced, although this applies to a greater extent to the sides which in many places have merged with the ground cover. Plants dominating the stump surface include Cladonia mitis, Cl. glauca, Cl. cenotea, Pohlia nutans, Cladonia gracilis and Cl. chlorophaea (Figs. 19B, C, 
$\mathrm{F}, \mathrm{H}, \mathrm{J})$. Cladonia sylvatica is also present in greater quantities than on younger stumps. The predominant species on the sides are Cladonia glauca (Fig. 19J), Cl. cenotea, Pohlia nutans (Fig. 19F) and Dicranum. polysetum.

Stumps over 30-year old have in nearly all cases decomposed entirely; at most their remains, covered with Cladonia glauca and Pohlia nutans, stand out above the herb layer.

\subsubsection{Conclusions and discussion}

The results obtained show that the flora of pine stúmps depends on the extent to which the stump has decayed, i.e. the chemical composition and structure of the wood, also on the light condition humidity and floristic composition of the community. By "community" here is meant the distinct stages of secondary succession in the Cladonio-Pinetum habitat.

The plant succession on pine stumps in the Cladonia-pine forest of the north-western Bory Tucholskie can be divided into four stages (Fig. 23):

1. the initial stage - up to 4-5 years after felling; characteristic of this stage is the appearance of only single plants on the stump surface; the stump sides are covered with bark which provides a habitat for epiphytes commonly found at the bases of the trunks of old pines;

2. the intensive colonization stage (invasion) - from 4(5) to 10(11) years after felling; the stumps are now rapidly overgrown; crustose lichen predominate (Lecidea humosa and L. granulosa); the centres of the surfaces of most stumps is still devoid of vegetation;

3. the optimal stage - 10(11)-15(16) years after felling - shows the greatest variety of flora; forest and non-forest species co-exist, with heliophilous plants showing a tendency to decline; predominant are crustose lichens and Cladonia species with unbranched podetiae;

4. regression:

a. domination of humusphilous species - 15(16)-25(30) years after felling; stumps are rotten, heliophilous species almost non-existent, dominant species include Cladonia species with branched podetiae (chiefly Cl. mitis) and humusphilous lichens and bryophytes (Cladonia glauca, $\mathrm{Cl}$. cenotea, Cl. digitata, Dicranum polysetum, Pleurozium schreberi);

b. terminal stage - from 25(30) years after felling, during which the stumps are finally decomposed and covered over with ground cover species, mainly Pleurozium schreberi and Dicranum polysetum.

The succession stages described above are short-lived and not very stable. With respect to the floristic composition, the numbers of ecological groups and morphological forms of lichens, they are similar to the initial stages of succession on soil (see 7.1.1.). Ahti and Hepburn (1967) have already drawn attention to this similarity. At the same time, 
the stages by which lichens overgrow decaying stumps in a dry pine forest are much like the succession of liverworts on wood and to the degrees of stump decay distinguished by Reyment-Grochowska (1950b) in the Silesian Beskid and by Berdowski (1974) in the Slęża Massif.

It is first and foremost the humidity of the air and substrate that decides whether bryophytes or lichens grow on decaying wood and what the quantitative relationships between them is. Raschendorfer (1946, quoted by Muhle, LeBlanc 1975) stated that liverworts play the leading part on rotting wood in damper forests, while mosses and lichens take over this role in less damp woodland. $\mathrm{Muhle}$ and $\mathrm{Le}-$ Blanc (1975), Tobolewski (1955), Cieśliński (1973) and Olech (1973) come to the same conclusions. Lichens definitely predominate in extremely dry habitats, such as those described in this thesis. Bryophytes are more numerous only on stumps situated in dense, shaded and relatively damp pine boskets.

The kind of epixylic flora found also depends on the degree of stump decay (Krusenstjerna 1945 quoted by A hti 1977; K is zk a 1964; $\mathrm{Muhle}$, LeBlanc 1975). Kiszka (1964) stated that the number of lichen species increases as the rotting of the wood progresses. This increase continues only up to certain limits and it is the intermediate stages which are the most abundant in species (see 7.1.3.4., and also Muhle, LeBlanc 1975; Shure, Ragsdale 1977).

The total decomposition of the pine stumps studied by the author takes about 30-40 years. Fre y (1959) and Stefureac (1969, quoted by $\mathrm{Muhle}$, LeBlanc 1975) give a similar time span. Were it not for the large quantities of lichens which overgrow the stumps, the rate of decay would probably be faster. In the initial stages, the wood is decomposed by fungi, and to a lesser extent by bacteria (Fog 1977), whose development is inhibited by lichen acids (M a licki 1965, 1967, 1970; H e nn ing s s on, L ünd ström 1970).

The initial stages of succession on decaying stumps is described by K iszka (1964) from the Niepolomice Forest and by Nowotarska (1976) from the Dulowa Forest near Cracow. K is z k a (1964) mentions three species which initiate the succession on stump wood: Lecidea humosa, L. flexuosa and Lecanora conizaea. The first two, occur along with Lecanora varia as pioneer forms on pine stumps in the Dulowa Forest (Nowotarska 1976). According to the above authors, these species are followed by Cladonia species, at first in the form of primary thallus flakes. This initial stage of succession and the lichen flora occurring in later stages of plant growth on pine stumps is very similar to the results presented in this thesis. Succession on spruce and fir stumps proceeds likewise, although during the various stages many species were found 
which do not occur on pine wood, e.g. from the family Caliciaceae and the genera Thelocarpon, Bacidia and Biatorella (K is z k a $1967 \mathrm{~b}$; O l e c h 1973).

\subsection{CHANGES IN THE LICHEN FLORA RESULTING FROM MINERAL FERTILIZATION}

In most papers dealing with the problem of fertilization in forestry the chief objects of interest have been the trees or the soil (e.g. B a ule, Fricker 1973; Krzyszkowski 1974; Olszowski 1976a, b, c, d; Olszowski, Warteresiewicz 1976; Kocjan 1977; Kennel, Franz 1977; Mucha et al. 1979; Galoux 1979). This is understandable as foresters are mostly interesed in trees; other plants are usually treated as a habitat factor of little moment. There are few papers concerned with the vascular plants of the ground cover (Cybulko 1968; Guzikowa et al. 1976; Szodfridt 1980). The effects of mineral fertilization on cryptogamic plants are practically unknown. Exceptions to this are the studies on higher fungi (Macromycetes) by Fiedler and Hunger (1963), Petersen (1970), Heinrich and Wojewoda (1976) and Salo (1979), also the papers on mycorrhizal fungi (Linnemann 1964) and bryophytes (Malyshev a 1981) in fertilized systems.

7.2.1. FLORISTIC RELATIONSHIPS IN THE CLADONIA-PINE FOREST PHYTOCENOSIS

\subsubsection{Methodological Assumptions}

The Przymuszewo F.I. was fertilized from the air in 1973 and covered over 100 forest sections with a total area of nearly 3000 ha belonging to the forestry sub-areas of Bukówki, Leśno, Parzyn, Przymuszewo and Widno. In 1975 the entire woodland complex between the villages of Lubnia and Wiele was fertilized. The total fertilizer dose was around $200 \mathrm{~kg}$ per ha NPK (granulated urea, superphosphate and $60 \%$ potassium salt). The effective dose was in fact much lower, perhaps by as much as $50 \%$. The reasons for this included technical errors in the distribution of fertilizer, losses due to the leaching of some components, their immobilization in the form of almost insoluble compounds (e.g. phosphorus) or the decomposition and release of elements into the atmosphere (e.g. nitrogen from urea). The loss of nitrogen from the study area amounted to $20-25 \%$ (data from the Dept. of Soil Science at the Nicholas Copernicus University in Toruń).

Research into the effects of mineral fertilization on the ground cover of Cladonia-pine forest was undertaken during the years 1975-79 on both fertilized and unfertilized land. On each of these two areas 50 experi- 


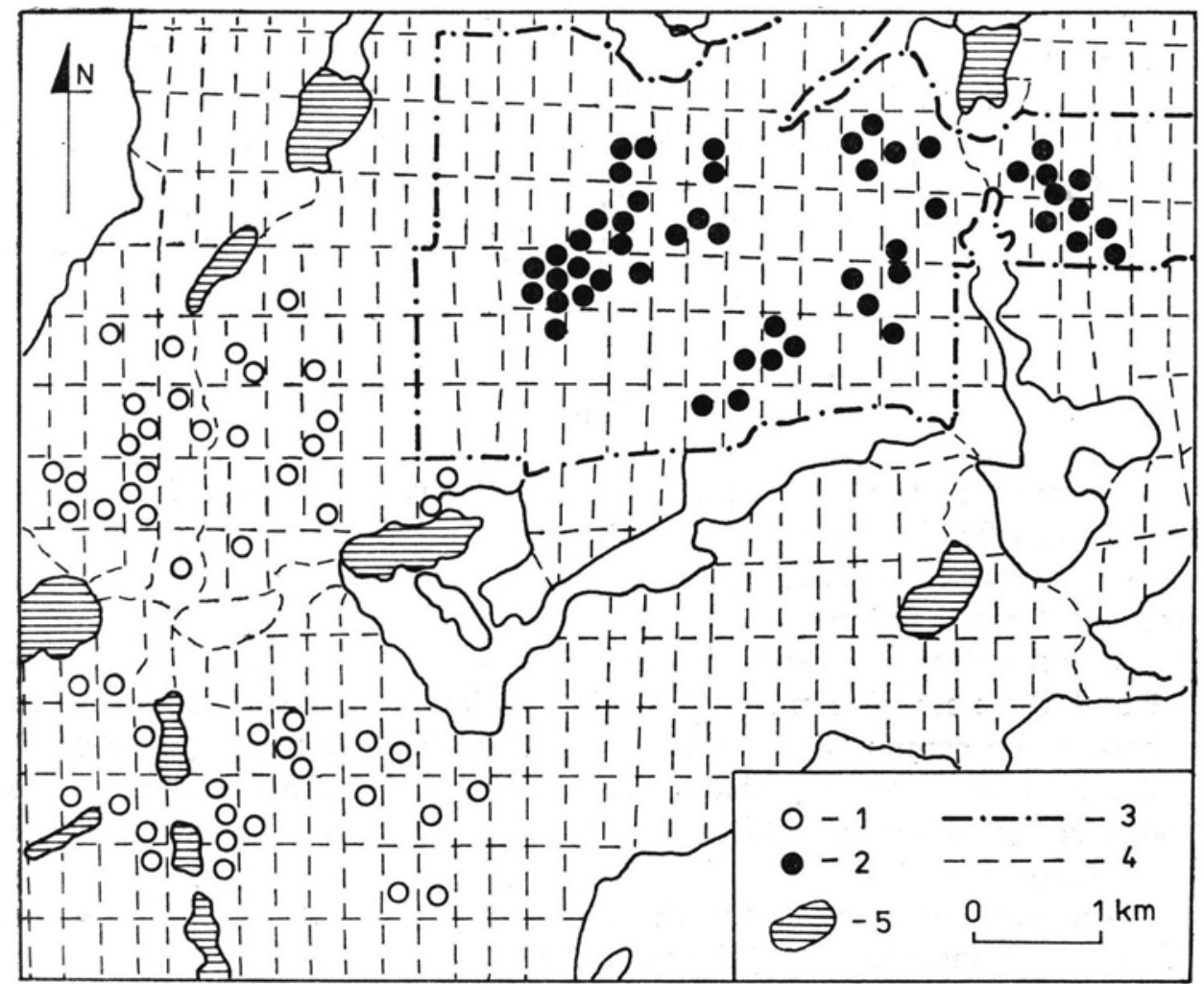

Fig. 25. Distribution of the experimental plots

1 - unfertilized, 2 - fertilized, 3 - boundaries of the fertilized area, 4 - boundaries of the forest section, 5 - lakes

Ryc. 25. Rozmieszczenie powierzchni doświadczalnych

1 - nienawożone, 2 - nawożone, 3 - granice obszaru nawożonego, 4 - granice oddziałów leśnych, 5 - jeziora

mental plots $10 \times 15 \mathrm{~m}\left(150 \mathrm{~m}^{2}\right)$ in area were marked out. Figure 25 shows their distribution.

The pine tree stands studied were divided into five age classes:

$$
\begin{array}{ll}
\text { Ia }- \text { up to } 10 \text { years } & \text { III }-41-60 \text { years } \\
\text { Ib }-11-20 \text { years } & \text { IV }-61-80 \text { years } \\
\text { II }-21-40 \text { years } &
\end{array}
$$

20 plots were located in each age group: 10 on fertilized land, 10 on unfertilized land. Parallel studies of this kind in pine stands of the same age class made it possible to identify the changes which took place both as a result of fertilization and in the secondary succession during tree growth. Work was started two years after fertilization, the state of the phytocenoses before fertilization being unknown. The results are nevertheless reliable because of the large number of repetitions in each 
age class and the establishment of two parallel sequences of sencondary succession.

Starting from 1975, phytosociological records were made on all the experimental plots every two years. Then the records from each year were compiled in tabular form, separately for each age class and year. The coefficient of cover and average cover (as a \%) for the various stages of the community development were calculated. These data were presented in the form of a common table and figures.

\subsubsection{Results}

The changes with took place on the experimental plots from 1975 to 1979 can be classified as being either a) due to natural factors in the normal course of secondary succession, or b) directly or indirectly due to mineral fertilization.

The secondary succession begins the moment the stand has been felled and the new pine plantation laid out, and takes such a course as a ensure the community maximum stability. The first stage consists of a drastic transformation, characteristic of which are great quantitative and qualitative changes in the herb and moss-lichen layers that are the consequence of:

- a tendency towards the maximum colonization of the soil surface during the establishment of the plantation;

- the appearance in huge number of heliophilous species, foreign to mature dry pine forest phytocenoses;

- the systematic exchange of non-forest species for forest ones as the pine trees increase in height.

A more detailed discussion of the changes taking place during secondary succession in a Cladonia-pine forest habitat will be found in chapter 7.1.1.

All the tree stands studied, beginning with the pine plantations, are consecutive stages of a sencondary succession in the same community, i.e. the Cladonia-pine forest. That is why there are more similarities than differences between the fertilized and unfertilized lands. Any discrepancies are to be found largely in the quantitative relationships and only to a much lesser extent in the qualitative relationships.

The greatest differences between the fertilized and unfertilized land were to be seen in the youngest communities (age classes Ia and Ib) (Table 14), which, as not very stable systems, are the most susceptible to various influences and react the most strongly to even minimal changes in the habitat conditions. The effect of mineral fertilizers is particulary evident in the herb and small shrub leyer (Fig. 26). Large quantities of Senecio silvaticus (Table 14) for this habitat appear on fertilized pine plantations. The presence of this plant, together with larger quanti- 

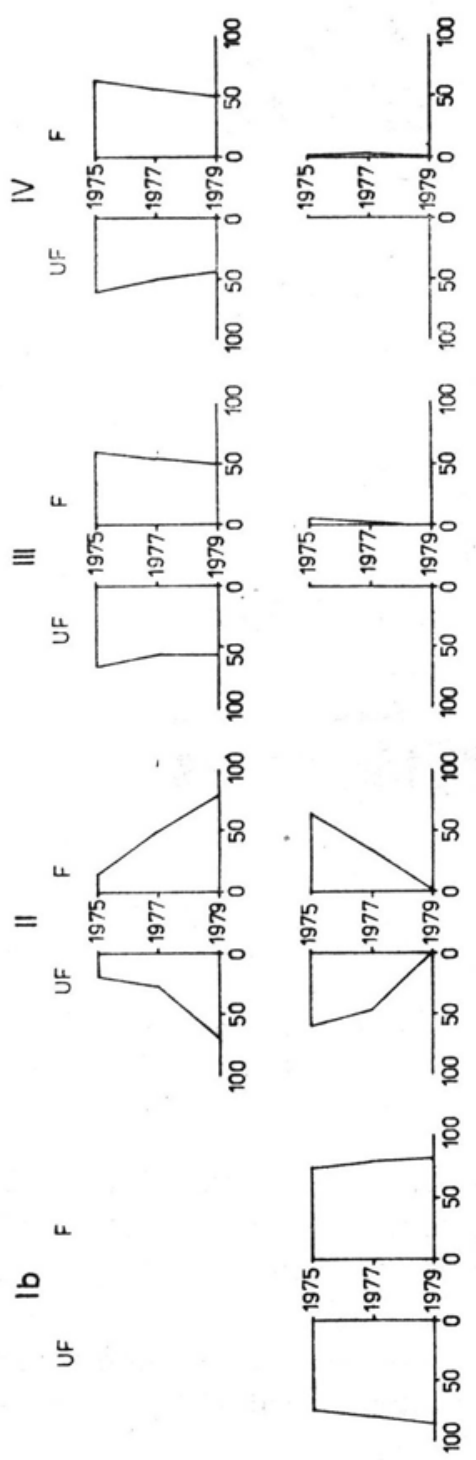

으

岇

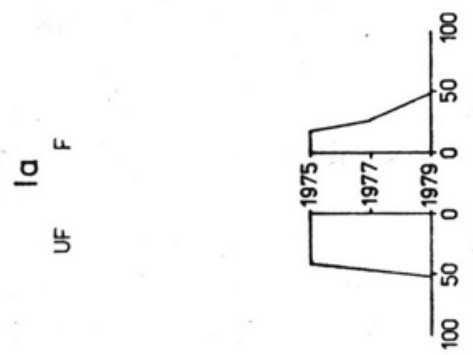

ס
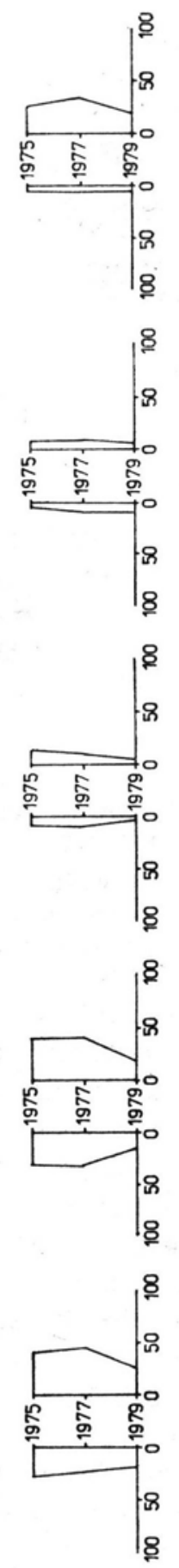

U

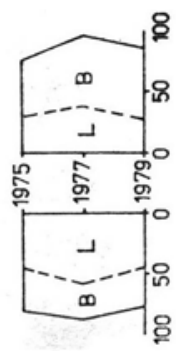

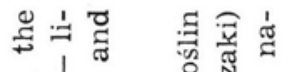

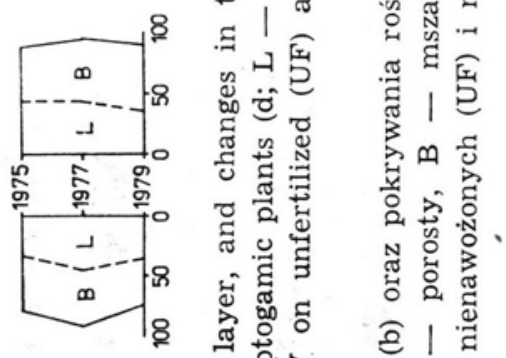
तै। है।

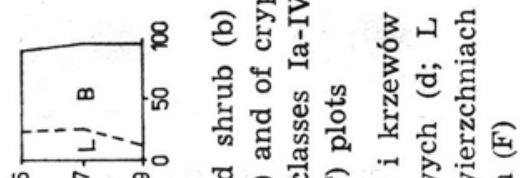

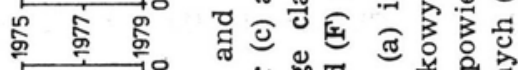

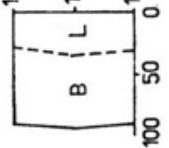
สิ ๑ త్త

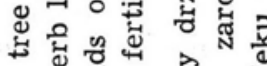

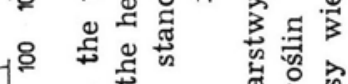

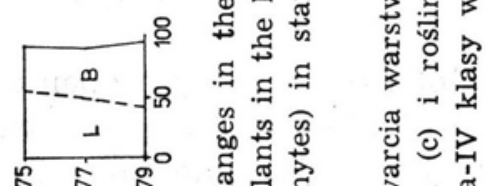

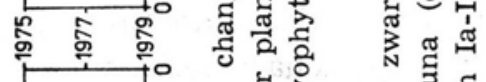

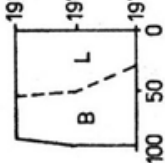

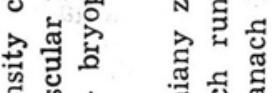
苞热 पू $m$ N

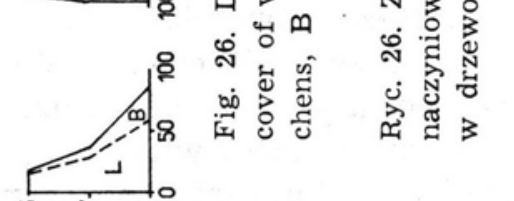



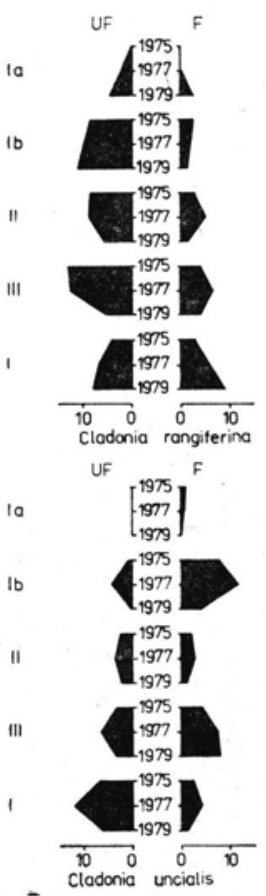
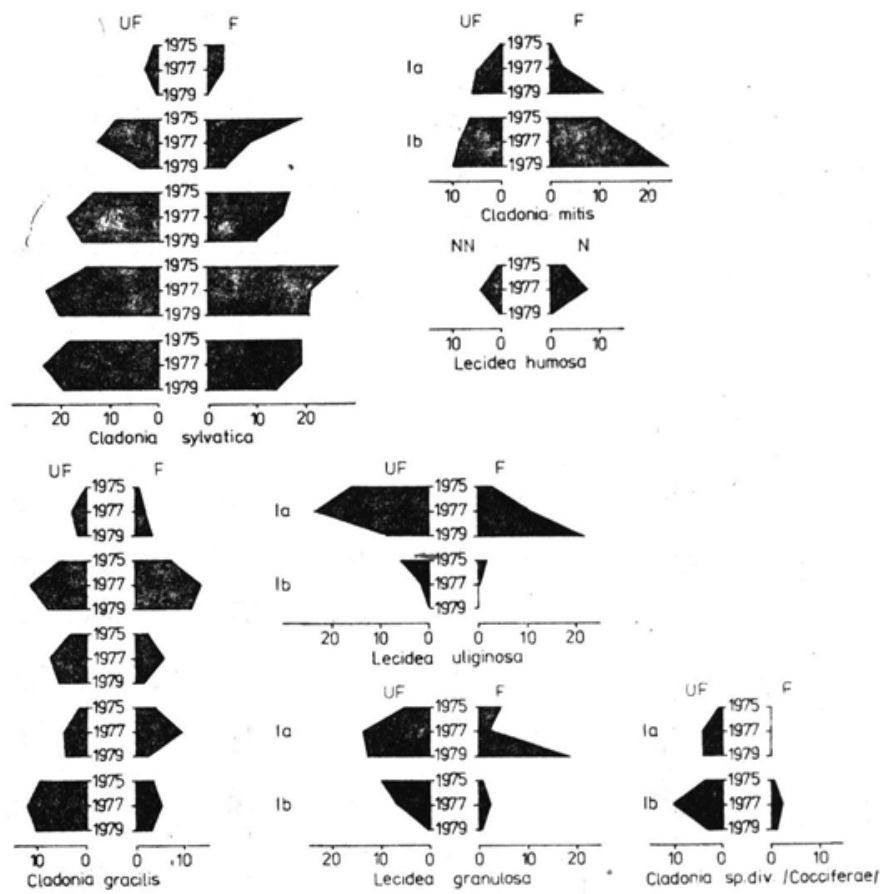

Fig. 27. Changes in the average cover of the more important species of lichens on unfertilized (UF) and fertilized (F) plots in particular age classes (Ia-IV) during 1975-1979

Ryc. 27. Zmiany średniego pokrywania ważniejszych gatunków porostów na powierzchniach nienawożonych (UF) i nawożonych (F) w poszczególnych klasach wieku drzewostanów (Ia-IV) w latach 1975-1979

ties ' of Lecidea humosa than are usual in unfertilized systems (Table 14, Fig. 27), indicates an increased nutrient content in the substrate, and also intensified mineralization of organic remains. The following turf plants are characteristic of fertilized areas of class Ia: Corynephorus canescens, Rumex acetosella and Spergula vernalis (Fig. 28). These three species are still found in 11-20-year old plantations (Table 14). A possible reason for this is the greater nutrient content of the substrate, which may well compensate for the insufficient light now reaching the floor as a result of the greater density of the boskets.

In older stands which have been fertilized, the herbs and small shrubs are more abundant than in unfertilized stands. This applies mainly to Deschampsia flexuosa (Fig. 28, Table 14). In some plantations Deschampsia flexuosa has spread so rapidly as to become a troublesome weed stifling the pine saplings. This grass no longer grows in boskets, but starting in thickets it becomes widespread in many patches of dry pine forest (Fig. 29). The favourable influence of mineral fertilization can also be seen on the example of Calluna vulgaris (Fig. 28, Table 14). 


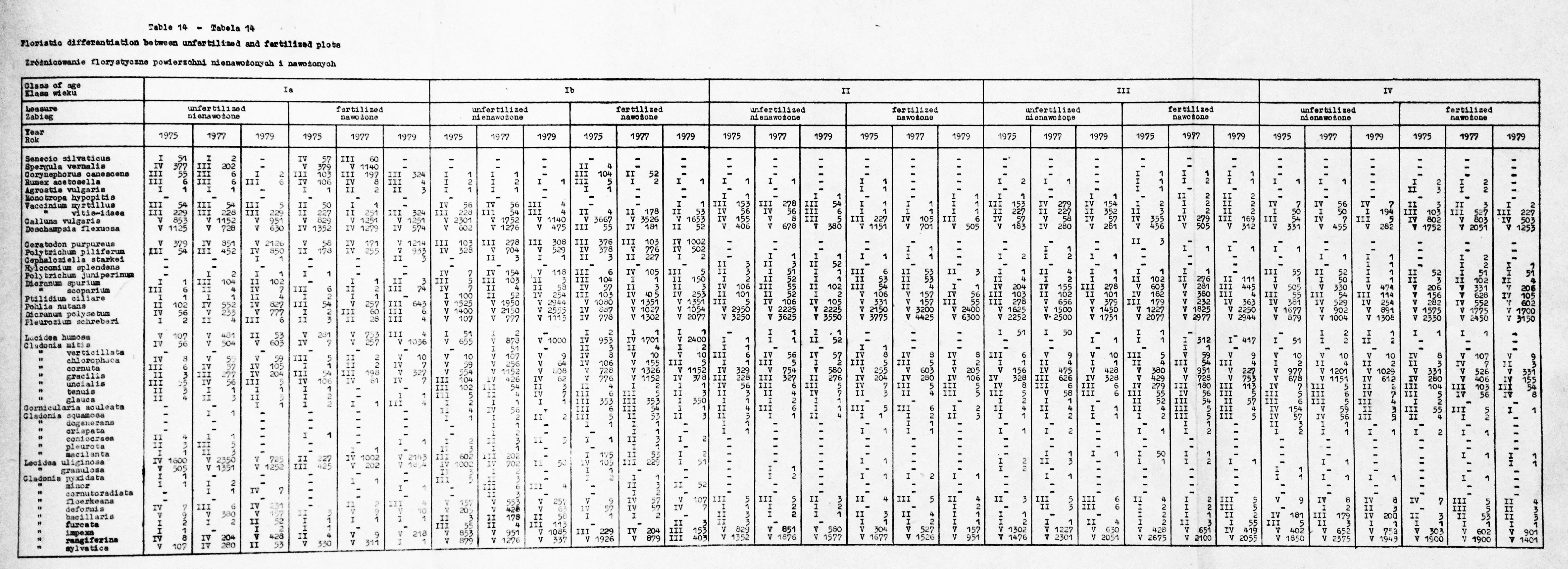



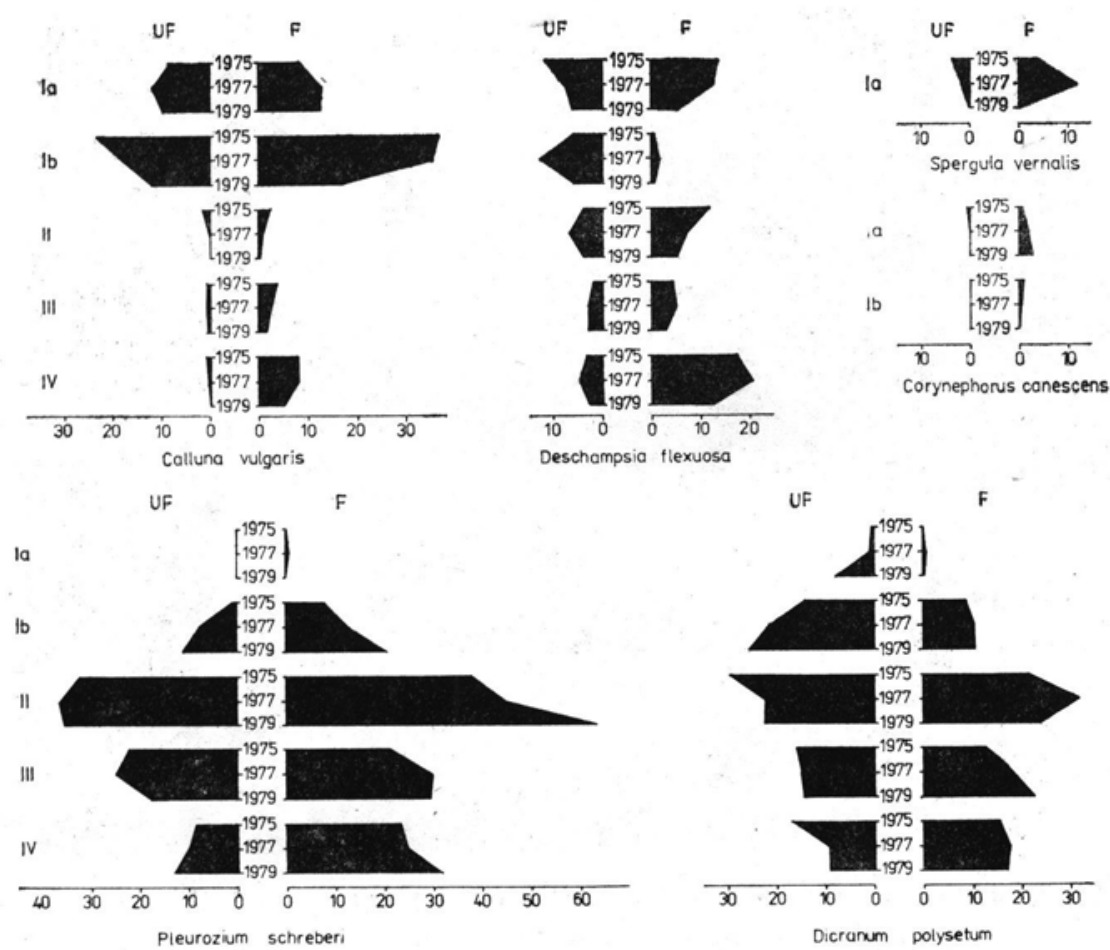

UF

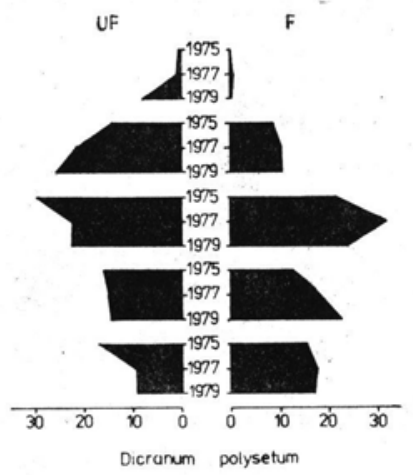

Fig. 28. Changes in the average cover of the more important species of vascular plants and bryophytes on unfertilized (UF) and fertilized (F) plots in particular age classes (Ia-IV) during 1975-1979

Ryc. 28. Zmiany średniego pokrywania ważniejszych gatunków roślin naczyniowych i mszaków na powierzchniach nienawożonych (UF) i nawożonych (F) w poszczególnych klasach wieku drzewostanów (Ia-IV) w latach 1975-1979

Heather appears in larger quantities in 6-7-year old plantations, attains its maximum development in 10-20-year old boskets, after which its cover and vitality become considerably reduced. In age classes III and IV Calluna vulgaris is always present, although in small quantities. The disappearance of heather from under the dense, strongly shaded 20-40year old pine stands is a natural occurrence. This is a consequence of the biological properties of this species, which in Cladonia-pine forests reproduces only vegetatively and has a maximum life-span of 28 years (K r ól 1963 - research carried out in part in the Przymuszewo F.I.), and which in any case is not a typically woodland species. On fertilized land Calluna vulgaris occurs in substantially greater numbers, its vitality is much increased, and in fertilized 20-40-year old stands, the largescale withering of heather plants is delayed by two years (Fig. 28).

In the moss-lichen layer which has been fertilized, there is a tendency for bryophytes to take over from lichens (Fig. 26). As a result, this layer becomes more moist than dry. 


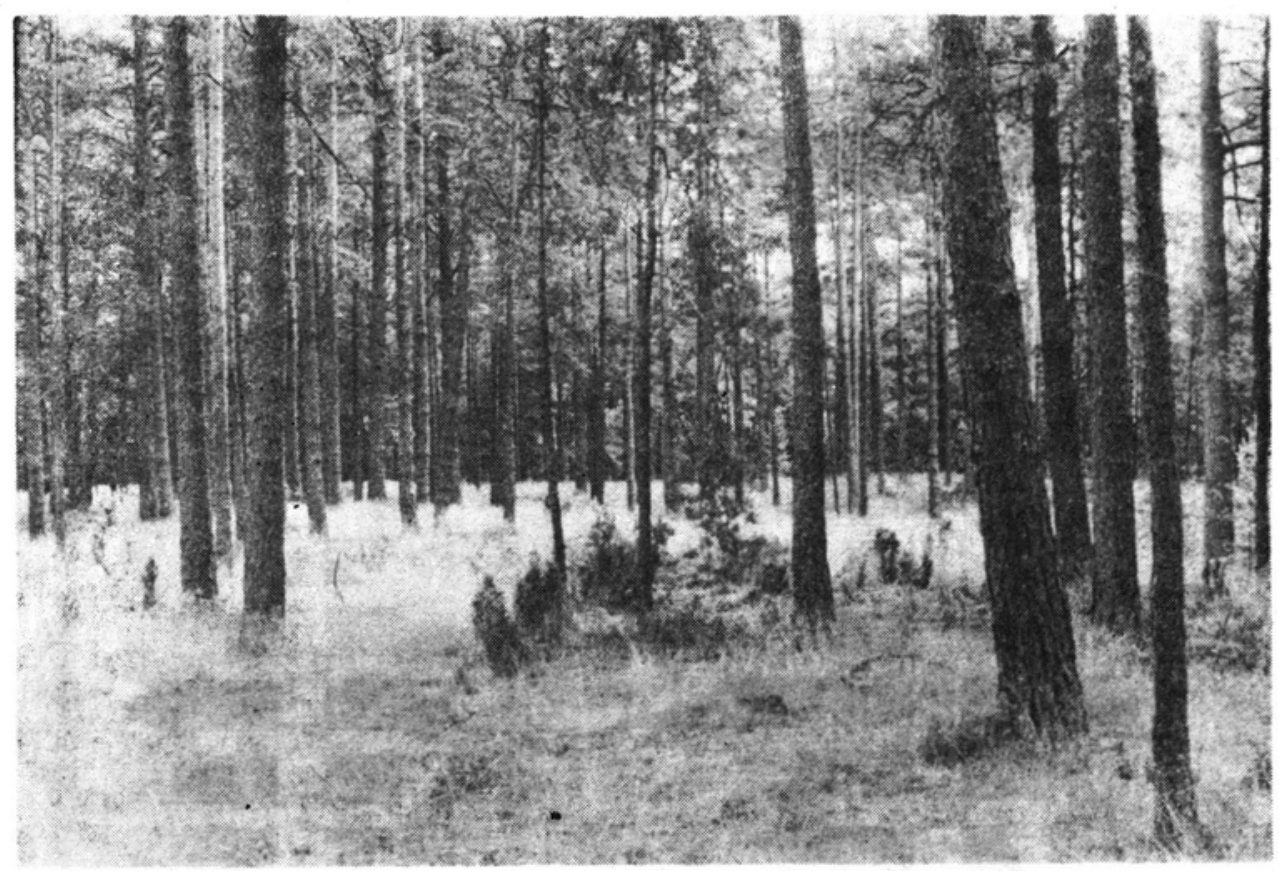

Fig. 29. Deschampsia flexuosa in the fertilized dry pine forest (Photo J. Herbich) Ryc. 29. Deschampsia flexuosa w nawożonym borze suchym (fot. J. Herbich)

Bryophytes dominating pine plantations and boskets of age classes Ia and Ib include Pohlia nutans, Ceratodon purpureus and Polytrichum piliferum, and in older stands Pleurozium schreberi and Dicranum polysetum. The first three species do not show any preference for either type of surface, growing in approximately equal quantities in both fertilized and unfertilized plantations. On the other hand, Dicranum polysetum and Pleurozium schreberi are far more abundant in fertilized systems, especially in older stands (Fig. 28, Table 14).

Lichens are more numerous in unfertilized than in fertilized systems (Fig. 26, Table 14). These differences are not very great, however, but the fact that they recur at each stage in the development on the stand does suggest that they are brought about by mineral fertilization. Most noticeable in fertilized pine plantations and boskets is the negligible occurrence of species from the section Cocciferae (Cladonia bacillaris, Cl. deformis, $\mathrm{Cl}$. digitata, $\mathrm{Cl}$. floerkeana, Cl. macilenta and $\mathrm{Cl}$. pleurota); they are fairly abundant in unfertilized systems (Fig. 27, Table 14). The quantitative analysis of Lecidea granulosa and L. uliginosa presents a similar though not quite so distinct picture, whereas Lecidea humosa and Cladonia mitis appear to prefer fertilized systems (Fig. 27). Lichens which dominate the older plantations and more mature stands in dry pine forest, i.e. Cladonia sylvatica, Cl. rangiferina, $\mathrm{Cl}$. gracilis and $\mathrm{Cl}$. uncialis, occur very numerously on both types of surface, although the 

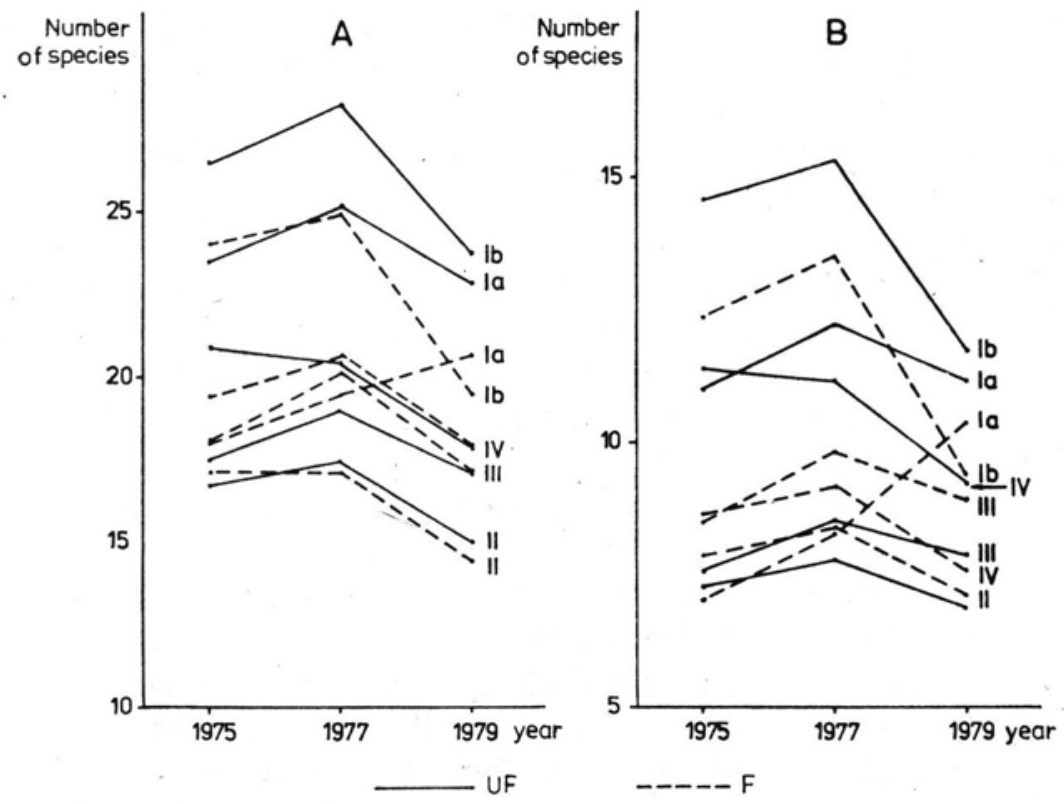

Fig. 30. Changes in the mean number of all species (A) and lichens (B) in phytosociological records on unfertilized (UF) and fertilized (F) plots in tree stands of various age classes (Ia-IV)

Ryc. 30. Zmiany średniej liczby wszystkich gatunków (A) oraz porostów (B) w zdjęciach fitosocjologicznych na powierzchniach nienawożonych (UF) i nawożonych (F) w drzewostanach różnych klas wieku (Ia-IV)

first two are somewhat more abundant in unfertilized forest (Fig. 27, Table 14).

The mean number of plant species, and also the number of lichens alone, is much greater in the first two age classes in unfertilized than in fertilized systems. In older stands these differences tend to even out and are almost insignificant (Fig. 30).

\subsubsection{Discussion and conclusions}

The results obtained in this study are not very precise as the phytosociological method tends to be rather subjective. At most they allow one to identify the course which the changes induced by mineral fertilization in a dry pine forest community are taking and to predict the reaction of a group of species (more rarely individual taxons). Any interpretation of the results is the more difficult because the doses of mineral fertilizer applied to the study area were relatively low and not evenly distributed.

The effects of fertilization are most evident in the reaction of herbaceous plants and small shrubs. In pine plantations this applies in part- 
icular to Senecio silvaticus. M a r kow ski $(1971,1982)$ has shown that the more fertile the habitat, the greater numbers of Senecio silvaticus in the post-felling communities. This species is found only occasionally in a Cladonia-pine forest; its constant occurrence in fertilized pine plantations indicates soil enrichment.

No direct information about the reaction of the herb and moss-lichen layer to mineral fertilization in the dry pine forest habitat was found in the available literature. Only Kocjan (1977), in describing the change of a forest habitat from dry pine forest to moist pine forest after fertilization, indirectly mentions the profound transformation of the herb layer as a result.

Research has however been carried out into the reaction of the plants of the herb layer to mineral fertilization in a moist pine forest ( $\mathrm{G} \mathrm{u} \mathrm{z} \mathrm{i-}$ $\mathrm{kow}$ a et al. 1976) and in a fertile deciduous forest (Szodfridt 1980). In the first case, the number of anthropophytes, and plants from meadows, post-felling areas and deciduous forests increased considerably in the ground layer two years after fertilization, whereas the reaction of plants characteristic of the class Vaccinio-Piceetea was minimal. The great changes observed were caused by the larger quantities of fertilizer used here than on the areas studied by the author. Such a strong reaction could not be expected on the much poorer dry pine forest habitat. The moss-lichen layer gradually became impoverished. In the most dynamic systems, reacting most strongly to changes in the habitat, i.e. in pine plantations and boskets, the number of species in fertilized phytocenoses is distinctly fewer than in unfertilized spots (see Fig. 30) The simplification of plant systems after fertilization with NPK has also been observed in meadow communities ( $\mathrm{P} \mathrm{a}$ a $\mathrm{l}$ t 1974 and the literature quoted therein).

The mineral fertilization of a fertile hornbeam-beech forest did not produce much change in its herb layer ( $\mathrm{Szodfridt} 1980$ ).

From the economic standpoint, the rapid growth of the herb layer after fertilization is often harmful in plantations, but useful in older stands. In the youngest pine plantations abundant herbage competes with the pine saplings and may stifle them or cause abnormal growth. One advantageous aspect attributed to the vascular plant species is that their uptake of mineral compounds is faster than that of trees, especially of compounds that are easily leached or decomposed. After the death of the plants, these compounds return to the soil and so the period during which the fertilizer has an effect is extended (Krzyszkowski 1974).

The only species of vascular plant which occurs more frequently and numerously on unfertilized lands is Vaccinium myrtillus (Table 14). Its reaction to mineral fertilization was also studied by $\mathrm{C} \mathrm{y} \mathrm{bulko} \mathrm{(1968).}$ The vitality of a moist pine forest increased after fertilization with 
NPK, and Vaccinium myrtillus produced more fruit. Guzikowa et al. (1976) observed the opposite trend: during the two years after fertilization this species reduced its cover from $12.4 \%$ to $9.9 \%$. It is difficult to assess what factors are responsible for the different reactions of Vaccinium myrtillus to mineral fertilization.

In the areas studied by the author, the moss-lichen layer is generally speaking at all stages of the development of the tree stand more mossy in fertilized systems than in unfertilized ones. The differences are not great, however, and taking errors in the method into consideration, it is difficult to draw any concrete conclusions from them about the reaction of the various species of bryophytes and lichens to mineral fertilization. None the less, as these differences do occur with measurable regularity at each stage of the secondary succession, they may be taken as sufficient evidence for drawing conclusions about the direction of development of the moss-lichen layer. As bryophytes show a tendency to expand on fertilized land while the area covered by lichens tends to contract, mineral fertilization obviously favours the former (see Fig. 26, Table 14).

The changes observed during these studies only indicate the direction in which transformations of the community are proceeding. If this trend were to continue, the end effect would be fairly large numbers of Deschampsia flexuosa, Calluna vulgaris and Vaccinium vitis-idaea in the herb layer with bryophytes dominating lichens in the "d" layer. A further stage in the transformation would be moist pine forest (LeucobryoPinetum). It is however difficult to imagine that a single dose of mineral fertilizer in a Cladonia-pine forest could produce such results. Once the mineral compounds introduced into the soil have exhausted themselves the community returns to the state which existed before fertilization. At this point already such observations as the disappearance of Senecio silvaticus in plantations and a general diminution of the vascular plant cover (see Fig. 26) is indicative that the period of change induced by the fertilizers is coming to a close. This is in agreement with $\mathrm{Kow}$ a lk owski (1979) who found that, after a single fertilization, the changes continued for 4-5 years and may persist for up to 10 .

When dealing with the problem of how the herb and moss-lichen layers vegetation reacts towards mineral fertilization, one should not overlook the effects of such an operation on the natural environment in general. Increasing eutrophization is a threat to the existence of many land and aquatic biocenoses. One cannot therefore agree with $\mathrm{Tram}$ pler (1979) and Szodfridt (1980) who suggest that the mineral fertilization of woodland should not adversely affect the overall environment. Dry pine forest complexes contain numerous raised and transition bogs, and also oligotrophic lakes which are often the habitat of rare and valuable plant and animal species. Their existence is endangered 
by the mineral nutrients being leached and washed out from the surrounding woodland (F a łtynowicz, Szmeja 1978). This aspect of the problem must not be ignored when analysing the profitability of fertilizing forests with mineral nutrients.

\subsubsection{THE BIOMASS OF THE HERB AND MOSS-LICHEN LAYERS}

The methods and results of research into the state of the biomass of the herb and moss-lichen layers of a Cladonia-pine forest and the effects of mineral fertilization of such a forest are given in a separate publication (F a łtynowicz 1983/1985). The final results and conclusions will now be presented.

The studies on the biomass were carried out in two experimental variants: I - control, II - nitrogen-fertilized (urea: dose - $200 \mathrm{~kg} / \mathrm{ha}$ sprayed from an aeroplane in 1976, $200 \mathrm{~kg} / \mathrm{ha}$ applied by hand in 1977). Material for assessing the state of the biomass was collected at the end of August and beginning of September, 4.5 months after the second fertilization. 28 random samples were taken in variant I, 27 in variant II. Each basic area was circular with a diameter of $28 \mathrm{~cm}\left(615.44 \mathrm{~cm}^{2}\right)$. The total biomass of the herb and moss-lichen leyers and the biomass of the vascular plants, lichens and bryophytes were worked out. Great care was taken as regards the methods used. How the samples were collected and prepared and the results mathematically analysed is discussed in detail in the above-mentioned paper (F a ł tynowicz 1983/1985).

Table 15 - Tabela 15

Mean biomass ( $\overline{\mathrm{x}}$ ) and confidence intervals for the mean $(\mathrm{L})$ of the most important herb and moss-lichen layers species in the control area (I) and that fertilized with nitrogen (II)

Średnia biomasa $(\mathrm{x})$ oraz półprzedziały ufności dla średniej (L) najważniejszych gatunków runa na powierzchni kontrolnej (I) i nawożonej azotem (II)

\begin{tabular}{|c|c|c|c|c|}
\hline & \multicolumn{2}{|c|}{ I } & \multicolumn{2}{|c|}{ II } \\
\hline & $\bar{x}\left(\mathrm{~g} / \mathrm{m}^{2}\right)$ & $\mathbf{L}$ & $\bar{x}\left(\mathrm{~g} / \mathrm{m}^{2}\right)$ & $\mathbf{L}$ \\
\hline Cladonia sylvatica & 70.42 & 30.25 & 32.95 & 17.41 \\
\hline Dicranum polysetum & 18.85 & 12.73 & 21.80 & 12.79 \\
\hline Calluna vulgaris & 20.34 & 13.68 & 7.20 & 8.32 \\
\hline Other lichens & 17.73 & 17.04 & 7.47 & 6.94 \\
\hline Inne porosty & & & & \\
\hline Other bryophytes & 9.01 & 10.31 & 10.89 & 10.45 \\
\hline Inne mszaki & & & & \\
\hline $\begin{array}{l}\text { Other vascular plants } \\
\text { Inne rośliny naczyniowe }\end{array}$ & 0.38 & 0,57 & 1.49 & 2.12 \\
\hline Total biomass & & & & \\
\hline Biomasa calkowita & 137.68 & 35.63 & 82.48 & 25.99 \\
\hline
\end{tabular}


The high value of the total biomass was found in the control area $\overline{\mathrm{x}}=137.68 \pm 35.63 \mathrm{~g} / \mathrm{m}^{2}$ ), of which $116.90 \pm 32.58 \mathrm{~g} / \mathrm{m}^{2}$ was the biomass of cryptogamic plants. The respective data for land fertilized with nitrogen were $82.48 \pm 25.99 \mathrm{~g} / \mathrm{m}^{2}$ and $73.78 \pm 22.63 \mathrm{~g} / \mathrm{m}^{2}$. The total biomass comprises the sum of the biomasses of 24 species, most of which (20) are cryptogamic plants. Only three of these (Cladonia sylvatica, Dicranum polysetum and Calluna vulgaris) are significant, and make up around $80 \%$ of this value (Table 15 ).

In both variants, lichens play a major part in the formation of the moss-lichen layer.biomass. In the control area, the lichen biomass is $89.03 \pm 32.19 \mathrm{~g} / \mathrm{m}^{2}$, but in the nitrogen-fertilized area, this biomass is less than half as much $-41.10 \pm 18.42 \mathrm{~g} / \mathrm{m}^{2}$. Cladonia sylvatica is the dominant species. The biomass of bryophytes is rather greater in the fertilized woodland $\left(32.68 \pm 17.05 \mathrm{~g} / \mathrm{m}^{2}\right)$ than in the control area $(27.87 \pm$ $\left.19.02 \mathrm{~g} / \mathrm{m}^{2}\right)$, but this difference is not statistically significant.

The results were analysed statistically. In the first place, the single analysis of variance test was applied (Oktaba 1976; $\mathrm{Strzałk} \mathrm{ow-}$ ski, Śliżyński 1978).

The species biomass turned out to be the feature with the widest variance. As it was impossible to find a significant difference between the biomass values of the various species in both areas, the material had to be grouped into five fractions: lichens, bryophytes, total cryptogamic plants, vascular plants and the total plants. In three such cases - lichens, total cryptogamic plants, total plants - the material was statistically non-homogeneous, thus significant differences could be found between the mean values of the biomass. These differences were checked using Duncan's new multiple test.

The results of this procedure throw some light on the directions which the changes occurring in the dry pine forest herb and moss-lichen layers are taking as a consequence of mineral fertilization. The quantitative and qualitative decrease of lichens on fertilized lands suggests the possibility that the dry pine forest is becoming a dry-moist forest, and in places perhaps even a moist one. The occurrence of such changes, their rate and irreversibility, depend mainly on which mineral fertilizers are applied, in what quantities and how many times the operation is repeated; one single fertilization gives transient effects (see 7.2.1., also B a u le, Fricker 1973, and others).

The high intra-object variability expressed by the high coefficients of variability (from 1.11 to 7.26 ) indicates that if the size of the experimental areas in this study is to be retained, the number of samples taken must be increased by a factor of from several tens to several hundreds. To draw conclusions on the basis of results obtained from areas smaller than those representative of a given phytocenosis is fraught with 
error; this confirms the conclusions which other authors have arrived at (e.g. Chojnacki 1974; Kwiatkowska, Dudziec 1974).

The relationship between the surface area and the biomass must be defined precisely: is it linear, or logarithmic as results from $\mathrm{Chojnac-}$ k i's work (1974)?

7.3. CHANGES IN THE LICHEN FLORA UNDER THE INFLUENCE OF OTHER ANTHROPOGENIC FACTORS

\subsubsection{THE INTRODUCTION OF UNDERBRUSH}

Research into the influence of the underbrush on the floristic composition of the herb layer was started in 1977 on an experimental area in section 301 of the Popówka forestry sub-area. From 1977 to 1981 a list was made of all the plant species which appeared in the neighbourhood of planted shrubs.

Species planted in the study area are Padus serotina, Sorbaria sorbifolia and also small numbers of Alnus incana. The large majority of

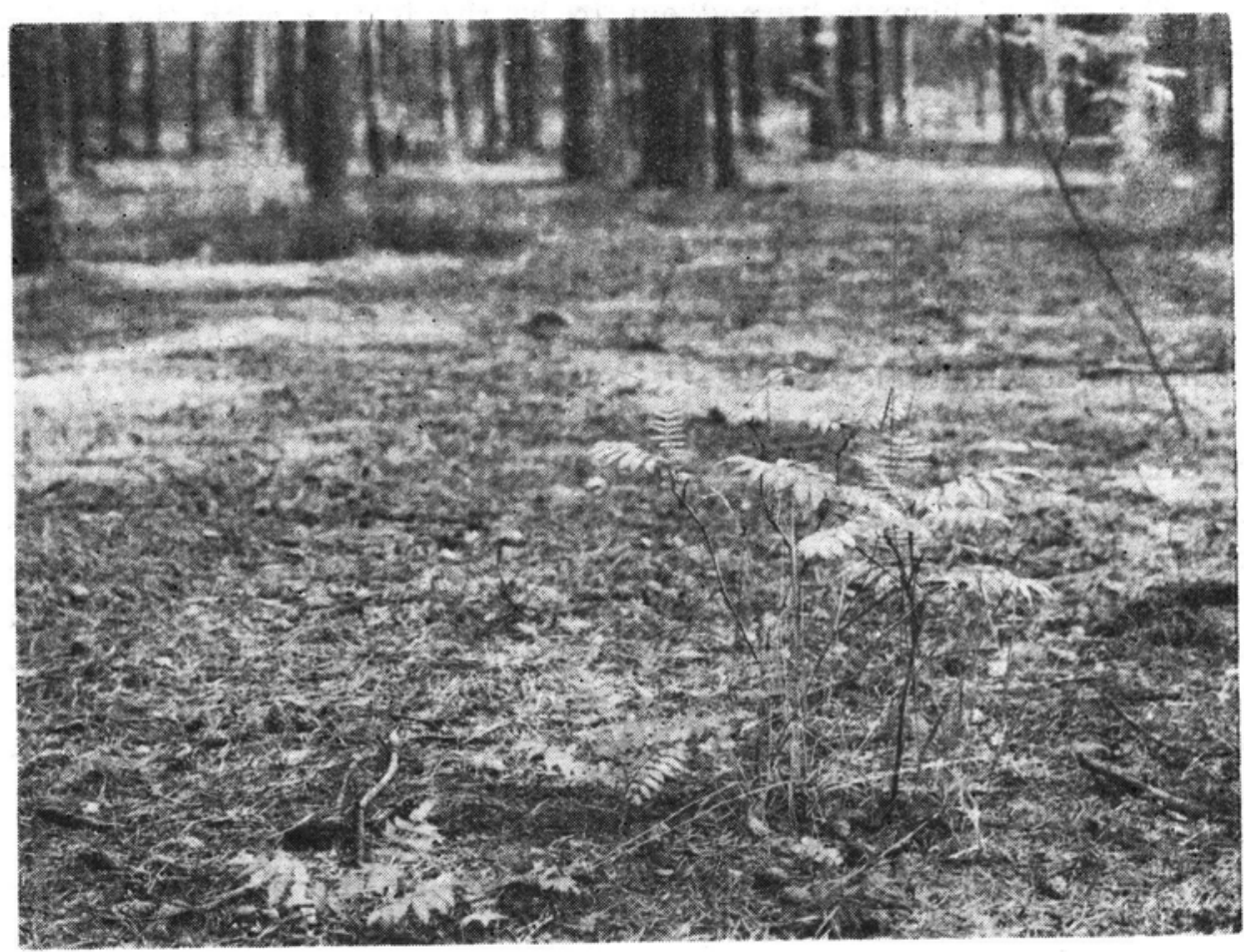

Fig. 31. Sorbaria sorbifolia in the dry pine forest - young specimens growing from stolons can be seen to the left of the shrub (Photo J. Herbich)

Ryc. 31. Sorbaria sorbifolia w borze suchym - na lewo od krzewu widać młode osobniki wyrosłe z rozłogów (fot. J. Herbich) 
shrubs planted have been growing well up to the present and are even reproducing vegetatively (Sorbaria sorbifolia - Fig. 31).

The underbrush was planted in hollows with a small addition of peat and mineral fertilizers in 1976. The destruction of the herb and mosslichen layers within a radius of $20-30 \mathrm{~cm}$ from the shrubs created suitable conditions for plants foreign to this habitat (Table 16). From 1977 to 1981 a total of 105 vascular plant species were found here.

The seeds and organs of vegetative reproduction of plants from other habitats arrived in the study area anthropochorically — chiefly meadow and ruderal species - and anemochorically - turf species.

\section{Table 16 - Tabela 16}

Number of vascular plant species in the ground cover

Liczba gatunków roślin naczyniowych runa

\begin{tabular}{|l|r|r|r|r|}
\hline \multicolumn{1}{|c|}{$\begin{array}{c}\text { Year } \\
\text { Rok }\end{array}$} & 1977 & 1978 & 1980 & 1981 \\
\hline $\begin{array}{l}\text { Total: } \\
\text { Ogółem: } \\
\text { typical to the habitat } \\
\text { typowych dla siedliska } \\
\text { foreign to the habitat } \\
\text { obcych siedliskowo }\end{array}$ & 58 & 66 & 61 & 68 \\
\hline
\end{tabular}

An analysis of the sociological provenance of the various species showed that $90.5 \%$ of the foreign ones were non-forest forms. Over half the species belong to two sociological groups - Molinio-Arrhenatheretea and Rudero-Secalietea s.l. Most of the 59 foreign species found recently, i.e. during 1981, occur in very small numbers - up to 10. Only 13 species occur in greater abundance, not counting the shrubs of the underbrush. They are Achillea millefolium, Agropyron repens, Agrostis vulgaris, Artemisia campestris, Centaurea scabiosa, Cerastium vulgatum, Medicago lupulina, Pimpinella saxifraga, Poa compressa, P. pratensis, Rumex acetosella, Trifolium repens and Veronica chamaedrys.

During the four years since the introduction of the underbrush the importance of all the foreign species has been negligible. As yet, they have not induced any observable changes in the herb layer. Most of them grow only within a radius of $20-30 \mathrm{~cm}$ from the shrubs, in the spots where the moss-lichen layer was destroyed (Fig. 32). A few plants are expanding somewhat and in 1981 were found at a greater distance from the underbrush shrubs, among synusiae of cryptogamic plants. They are almost all perennials reproducing, i.a. with the aid of stolons, and include Achillea millefolium, Agropyron repens, Fragaria vesca, 


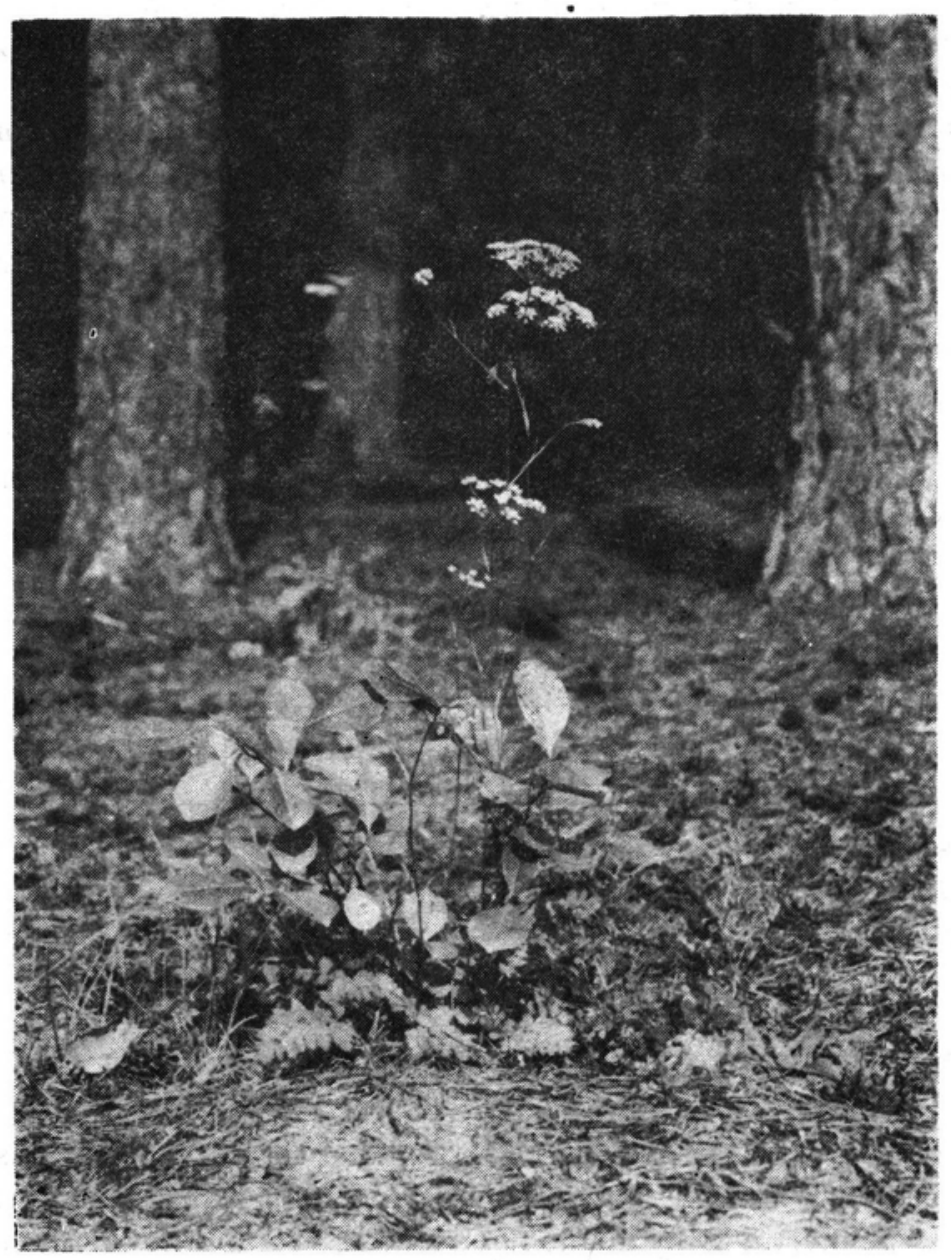

Fig. 32. Species foreign to the habitat (Pimpinella saxifraga, Centaurea scabiosa, Poa pratensis and Medicago lupulina) growing around Padus serotina (Photo J. Herbich)

Ryc. 32. Gatunki obce siedliskowo (Pimpinella saxifraga, Centaurea scabiosa, Poa pratensis i Medicago lupulina) skupione wokół Padus serotina (fot. J. Herbich)

Poa pratensis, Rumex acetosella, Trifolium repens and Cerastium vulgatum. It is quite likely that as the underbrush grows larger, and thus as the amount of dead organic matter falling on to the surroundings increases, some of the above-mentioned plants may become more important, and may even become a permanent feature of the habitat, improving its properties at the same time. This could alter the nature of the Cladonio-Pinetum herb and moss-lichen layers. Lichens being the first to be eliminated. That a dry pine forest could be transformed into a moist one by means of phytomelioration linked with fertilization is a possibility suggested in one or two papers (e.g. Milew ski 1970; K o c ja n 1977). 
Litter-raking and cattle-grazing exert an extremely adverse influence on woodland habitats. Many workers have drawn attention to this fact (e.g. Ka wecki 1939; O rłoś 1961; Dzięciołowski 1963; M olenda 1963; Sokołowski 1970b, 1976, 1980; Boiński 1976; Kreutzer 1979). Having studied the changes in a moist pine forest due to intensive litter- and bryophyte-raking, Sokołowski (1970b, 1976) stated that the procedures cause the disappearance of mosses and herbage, and a considerable reduction of small shrubs, giving preference to lichens and Dicranum scoparium. The losses of nutrient elements as a result of litter-raking are enormous. For a pine forest these losses amount to (in $\mathrm{kg} / \mathrm{ha}$ ): $\mathrm{N}-1000-1400, \mathrm{P}-100-150, \mathrm{~K}-350-450, \mathrm{Ca}-$ $500-700$ and $\mathrm{Mg}-100-150$ (K r e u t z e r 1979).

Cattle-grazing causes adverse changes in the physical properties of the soil. Compaction takes place, and the heat capacity of the surface layers increases ( $\mathrm{K} \mathrm{r}$ a p f e $\mathrm{n} \mathrm{b}$ a u e $\mathrm{r}$ 1977).

I should now like to give some indication of the kind of changes resulting from these activities in coniferous woodland communities in the Bory Tucholskie. Research into this problem is still in progress and the full results will be published after its completion.

Two pairs of phytosociological records were compiled in coniferous forest phytocenoses in the central Bory Tucholskie, near Szumiąca and Legbąd. Each pair of records covered patches several hundred metres distant from each other. The substrate was identical, and the patches differed only in the way they had been managed: one was undegraded, the other degraded as a result of litter-raking and cattle-grazing.

The moist pine forest on undegraded land near Szumiąca and Legbąd should be classified as belonging to the Leucobryo-Pinetum association (Table 17, rec. 1-2). The tree stand is of pine, and the shrub layer is sparse. Coniferous forest species dominate the abundant herb-small shrub layer (cover 35\% and 50\%): Melampyrum pratense, Vaccinium. myrtillus and V. vitis-idaea, also Deschampsia flexuosa and Calluna vulgaris. The moss layer is very well developed (cover $90 \%$ and $95 \%$ ) and basically comprises three species of moss: Pleurozium schreberi, Dicranum polysetum and Hylocomium splendens. Single lichens from the genus Cladonia occur here and there.

The phytocenoses on degraded land can be classified as an anthropogenic form of Cladonio-Pinetum (Table 17, rec. 3-4). This shows the following differences from undegraded land:

- the floristic composition is altered - many lichen species appear;

- the number of species is larger; the numbers of vascular species in both communities is approximately the same, but there are twice as many cryptogamic species in degraded communities;

- the numerical relationships are altered: in degraded phytocenoses 
Table 17 - Tabela 17

kon-degraded forest/Leucobryo-Pinetum and degraded

forest /Cladonio-Pinetum/ in Legbąd and Szumiąca

B6r niezdegradowany /Leucobryo-Pinetum/ i zdegradowany /Cladonio-Pinetum/ w Legbądzie i Szumiącej

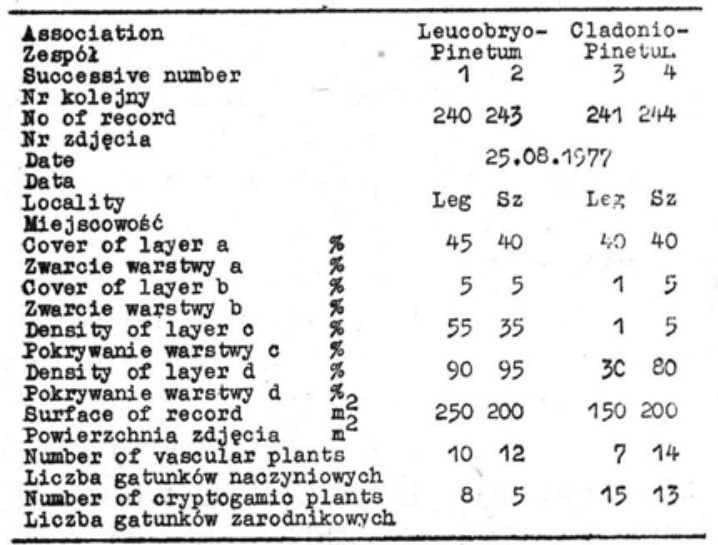

Ch. Vaccinio-Piceetea:

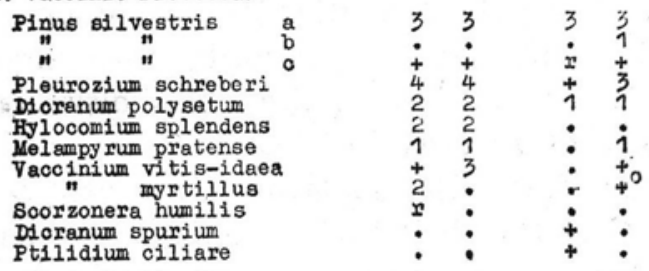

Ch. Cladonio-Pinetum:

Cladonia sylvatica

$\begin{array}{cl}n & \text { gracilis } \\ \text { n } & \text { rangiferina } \\ n & \text { furcata } \\ n & \text { squamosa } \\ n & \text { degenerans } \\ n & \text { impexa } \\ n & \text { deformis } \\ & \text { tenuis }\end{array}$

Accompanying species:

Gatunks towarzysz:日e:

Juniperus communis b

Deschampsia flexuosa

Calluna vulgaris

Cladonia chlorophaea

Sol1dago virga-aurea

Festuca ovina

Betula verrucosa

Quercus sessilis

Cladonia cornuta

n minor

Sorbus aucuparia

Agrostis vulgaris

Calamagrostis arundinacea

Carex arenaria

Cladonía coniocraea

Sieglingia decumbens

Cladonia glauca

" uncialis

Hieracium umbellatum

Prangula alnus

Polytrichum juniperinum

Rumex acetosella

Thymus serpylium 
the vascular plant cover is decidedly smaller $(1 \%$ and $5 \%)$, that of cryptogamic plants somewhat smaller $(30 \%$ and $80 \%)$; there are few bryophytes, lichens predominate.

In a raked and grazed forest, Cladonia species do not form larger, well-developed clumps. Their podetiae are abnormally low and distorted and extend along the substrate. The colour of the podetiae usually deviates from that typical of each species and approaches that of rotting, fallen pine needles, i.e. dark grey, greyish-brown, brown, brownishblack. This type of growth and colouration are the reaction towards specific factors such as biting, trampling, raking etc. (Cladonia species show great phenotype variability - see Sandstede 1931; Moty$\mathrm{k} \mathrm{a}$ 1964).

In recent years, the lack of straw has caused litter-raking to increase in both private and state-owned forests. Any further spread of this procedure needs to be prevented as its adverse effects on woodland habitats must not be underestimated.

\section{SUMMARY AND CONCLUSIONS}

1. The studied area was the dry pine forest complex situated on outwash plain sands in the north-western part of the Bory Tucholskie.

2. The dominant plant community in the studied area is Cladoniapine forest (Cladonia-Pinetum) which exist here in a somewhat impoverished suboceanic form. Leucobryo-Pinetum, Vaccinio uliginosi-Pinetum and small tracts of deciduous woodland cover much smaller areas. A not unimportant feature of the vegetation are the poor, dry heathlands.

3. Lichens are very common and of great importance in the CladonioPinetum and also in the various stages of the secondary succession leading to the formation of patches of this association. Because of their narrow ecological range, many of these lichens are useful, sensitive indicators of changes in the habitat.

4. 157 species of lichens were found in the studied area; of these the largest number $-34-$ and at the same time the most abundant were Cladonia species. In particular, Cladonia sylvatica, Cl. mitis, Cl. rangiferina, $\mathrm{Cl}$. uncialis and $\mathrm{Cl}$. gracilis are dominant cryptogamic plants in dry pine forest, on heaths and dry grassland. Also widespread are Lecidea granulosa and L. uliginosa, and of the epiphytic lichens Hypogymnia physodes, Lecanora conizaea, Lepraria aeruginosa and Pseudevernia furfuracea. One species of lichens - Usnea perplectans - has not been recorded before in Poland, and several were found which are very rare in Poland and Central Europe: Cetraria nivalis, Cyphelium calicioforme, Umbilicaria deusta, Usnea glauca, U. laricina, U. wasmuthii, Bryopogon implexus and B. tatarkiewiczii. 
5. The pine plantation having been estabilished, the following stages in the herb and moss-lichen layers development during the secondary succession in the dry pine forest habitat may be distinguished:

a. colonization and domination by heliophilous species;

b. coexistence of heliophilous and shade-tolerant species with a tendency for the former to decline;

c. mossy stage;

d. typically developed Cladonia-pine forest phytocenosis.

Each stage of the succession is distinguished by the presence or significantly greater constancy and quantities of a given group of species, mostly cryptogamic plants. The first two stages are characterized by the most radical changes in the quantity and quality of the herb and mosslichen layers. These changes are expressed by a tendency towards the maximum colonization of soil uncovered during planting, the mass occurrence of non-forest species foreign to the mature dry pine forest, and the systematic exchange of non-forest species for forest species as the pines grow. Man's continual interference with the secondary succession tends to accelerate this process.

6. The succession stages on decaying pine stumps are correlated with the initial stages in the succession of terricolous communities in a dry pine forest. There are four distinct stages of succession on decaying wood:

a. initial;

b. intensive colonization (invasion);

c. optimal;

d. regression: - domination of humusphilous species;

- terminal.

The flora of pine stumps depends on the exent to which the wood has decomposed, the illumination and humidity, and the floristic composition of the community in which the stumps occur.

7. 35 lichen species were found in the studied area which are epiphytes of Pinus silvestris. Most of them are rare or not very frequent. The commonest and most abundant include Hypogymnia physodes, Lecanora conizaea, Lepraria aeruginosa, Pseudevernia furfuracea, Parmeliopsis ambigua, Bacidia chlorococca and Lecidea scalaris. The epiphytic flora of pines changes with tree growth: the number of species and their cover increase, lichens with foliose thalli increasingly dominate the trees, species typical of thin branches (Bacidia chlorococca, Cetraria sepincola, Lecanora conizaeoides and L. umbrina) decline.

8. An investigation of the plant biomass confirmed the predominance of lichens in the Cladonia-pine forest. It was found that:

a. the total biomass of the vascular plants, lichens and mosses in a Cladonia-pine forest with pines in age class IV amounts to 137.68 $\pm 35.63 \mathrm{~g} / \mathrm{m}^{2} ; 85 \%$ of this total is made up by cryptogamic plants;

b. three species: Cladonia sylvatica, Dicranum polysetum and Calluna 
vulgaris are responsible for the value of the total biomass in the dry pine forest studied;

c. lichens are of the greatest significance $\left(89.03 \pm 32.19 \mathrm{~g} / \mathrm{m}^{2}\right)$. Cladonia sylvatica is the dominant species here, making up ca. $80 \%$ of the total. Apart from this, $\mathrm{Cl}$. gracilis and $\mathrm{Cl}$. uncialis are also of some import.

9. Having analysed the material collected for the purpose of determining the biomass, the following conclusions may be drawn:

a. the "species biomass" shows the greatest variability; evidence for this are the very wide confidence limits and the high coefficient of variability; the reason for this is the very low number of experimental samples - for a sampling area of the size studied, the number of samples should be greater by a factor of at least several tens so that the total area studied is the same as or greater than as area representative for the phytocenosis. To analyse such an enormous quantity of material would, however, cause serious technical difficulties;

b. in future it will be necessary to determine the nature of the relationship between the surface area and the biomass: whether it is linear or logarithmis. This will give the results a greater credibility.

10. Cladonia-pine forest is that type of community which arose as a consequence of periodic agricultural exploitation of the habitats and wasteful forest management, without any compensation for the loss of organic matter. The various agricultural activities significantly affect the composition, structure and dynamics of the phytocenoses.

11. Floristic changes resulting from mineral fertilization take place at the same time as changes due to the succession; interpretation of results if therefore rendered more difficult. Even so, it is possible to draw reasonable conclusions about the trends in the transformation of the vegetation of a dry pine forest after mineral fertilization.

a. The following changes observed in the flora of fertilized plantations:

- Senecio silvaticus and the turf plants Spergula vernalis, Corynephorus canescens and Rumex acetosella appear in fairly large number;

- the number of vascular plants, particularly Deschampsia flexuosa, increases;

- bryophytes increase in number, lichens decrease;

- in number of cryptogamic species decreases.

These facts suggest the possibility that the dry pine forest is being transformed into a.dry-moist pine forest or even a moist one. Such changes will not take place after a single fertilization, the effects of which are short-lived.

b. The results of investigating the plant biomass of a dry pine forest confirm the effects of fertilization: 
- the biomass of lichens is more than twice as great in unfertilized phytocenoses than in fertilized ones;

- the proportion of various herb and small shrubs species in the total biomass alter: Calluna vulgaris was more common in the control area, Deschampsia flexuosa in the fertilized area.

12. The effects of fertilization were quite out of proportion to expectations. The profitability of this operation ought to be recalculated. Apart from short-term economic benefits, one must take into account the effects of fertilization on the entire natural enyironment, and especially the adverse influence it exerts on the nearly aquatic and raisedbog ecosystems.

13. After planting shrubs to form an underbrush in the dry pine forest, many species foreign to this habitat appeared. During the four years of observations, their numbers did not alter but significant changes in the species composition did take place. These plants did not expand, with the exception of a few species forming surface or underground stolons. Up till now, the underbrush has not visibly affected the lichens and bryophytes.

14. Litter-raking and cattle-grazing seriously degrade the habitat. It was found that as a result of this primitive use of the moist pine forest, the substrate and flora were considerably impoverished. In fact, the community turned into a dry pine forest of the poorest type with a tree stand of little value.

\author{
Dr. Wiesław Faltynowicz \\ Department of Plant Ecology \\ and Nature Protection, \\ University of Gdańsk, \\ Czołgistów 46, 81-378 Gdynia, Poland
}

\title{
9. STRESZCZENIE
}

Terenem badań był kompleks suchych borów sosnowych, położony na piaskach sandrowych w północno-zachodniej części Borów Tucholskich, u styku granic województw bydgoskiego, gdańskiego i słupskiego (ryc. 1, 2).

Celem pracy było przedstawienie udziału i roli porostów oraz ich sukcesji w kolejnych etapach rozwoju boru chrobotkowego, od momentu wycięcia drzew do w pełni wykształconych fitocenoz borowych. Analizie poddano florę naziemną, epifityczną i epiksyliczną. Zwrócono dużą uwagę na wpływ tradycyjnych zabiegów pielęgnacyjnych prowadzonych w uprawach, młodnikach i dojrzałych drzewostanach na stosunki ilościowe i jakościowe wśród roślin runa, kory sosen i murszejących pniaków sosnowych. Drugim podstawowym celem pracy było określenie wpływu nawożenia mineralnego i wprowadzania podszytów na roślinność runa w borze chrobotkowym, głównie na porosty. W celu przedstawienia wpływu wszystkich ważniejszych zabiegów gospodarczych na fitocenozy Cladonio-Pinetum zasygnalizowano również, na podstawie wyników wstępnych badań, zmiany, jakie zachodzą w rezultacie prymitywnego użytkowania lasu (wypas bydła, grabienie ściółki). W trakcie badań zbierano materiały do flory porostów tego obszaru, co 
pozwoliło wypełnić ,białą plamę" na mapie lichenoflory Polski. Przedstawiono również fitosocjologiczną charakterystykę ważniejszych zbiorowisk roślinnych z udziałem porostów.

Dominującym zbiorowiskiem roślinnym na badanym obszarze jest bór chrobotkowy (Cladonio-Pinetum), występujący w nieco zubożałej odmianie suboceanicznej (tab. 3). Znacznie mniejszą powierzchnię zajmują: Leucobryo-Pinetum (tab. 5), Vaccinio uliginosi-Pinetum oraz fragmenty lasów liściastych. Duży stosunkowo udział w szacie roślinnej mają ubogie i suche wrzosowiska oraz murawy psammofilne: Corniculario-Cladonietum mitis (tab. 6) i Spergulo-Corynephoretum (tab. 7).

W badanym terenie znaleziono 157 gatunków i kilkadziesiąt niższych jednostek taksonomicznych porostów. Ich wykaz zamieszczono $\mathrm{w}$ oddzielnym opracowaniu (F a 1 t y nowicz 1980). Najbogatszy w gatunki i najliczniej reprezentowany jest rodzaj Cladonia (34 gatunki). Zwłaszcza Cladonia sylvatica, Cl. mitis, Cl. rangiferina, $\mathrm{Cl}$. gracilis i $\mathrm{Cl}$. uncialis są roślinami panującymi w fitocenozach boru suchego, wrzosowisk i suchych muraw. Ponadto dużą rolę przestrzenną odgrywają Lecidea granulosa i L. uliginosa, a z porostów epifitycznych Hypogymnia physodes, Lecanora conizaea, Lepraria aeruginosa i Pseudevernia furfuracea. Na szczególną uwagę zasługuje duża liczba gatunków z rodzajów Usnea (8) i Bryopogon (7), a także szerokie rozprzestrzenienie i obfite występowanie wielu $\mathrm{z}$ nich. We florze porostów stwierdzono jeden gatunek nowy dla Polski - Usnea perplectans, a także kilka bardzo rzadkich na niżu Europy Srodkowej i kraju: Cetraria nivalis, Cyphelium caliciforme, Bryopogon implexus, B. tatarkiewiczii, Umbilicaria deusta, Usnea glauca, U. laricina i U. wasmuthii.

Porosty naziemne odgrywają dużą rolę w fitocenozach Cladonio-Pinetum, a także w poszczególnych stadiach sukcesji wtórnej, prowadzącej do powstania tego zespołu. W procesie sukcesji wtórnej na siedlisku boru chrobotkowego wyróżniono następujące etapy rozwoju runa:

1. zasiedlania i dominacji gatunków światłolubnych (do 7-10 lat po wyrębie);

2. koegzystencji gatunków światłolubnych i cienioznośnych, z zaznaczającą się juź tendencją do ustępowania tych pierwszych (od 7-10 do 20-25 lat);

3. mszysty (od 20-25 do 40-45 lat);

4. typowo wykształconych fitocenoz borowych (powyżej 40-45 lat).

Każde stadium sukcesyjne ma grupę gatunków wyróżniających, głównie roślin zarodnikowych (ryc. 11). Najbardziej burzliwy i charakteryzujący się największymi zmianami ilościowymi i jakościowymi w runie jest etap pierwszy i drugi. Zmiany w nich zachodzące polegają przede wszystkim na: - dążeniu do maksymalnego zasiedlenia odkrytej $\mathrm{w}$ trakcie zakładania uprawy powierzchni gleby; - masowym pojawieniu się gatunków nieleśnych, obcych dla dojrzałych fitocenoz boru suchego; - systematycznej, w miarę wzrostu sosen, wymianie gatunków nieleśnych na leśne (ryc. 12). Dużą rolę odgrywają tu skorupiaste, naziemne gatunki z rodzaju Lecidea, których plechy, pokrywające zwartą skorupą piasek, utrudniają w znacznym stopniu erozję wodną i eoliczną, chronią podłoże przed wysychaniem, a obumierając stają się zaczątkiem warstwy próchniczej. Proces sukcesji wtórnej przebiega w warunkach ciągłej ingerencji człowieka, która w ogólnym rozrachunku przyśpiesza tok przemian sukcesyjnych.

$\mathrm{Z}$ początkowymi etapami następstwa zbiorowisk naziemnych na siedlisku boru suchego skorelowane są stadia sukcesyjne na murszejących pniakach sosnowych. Wyróżniono cztery etapy sukcesji na butwiejącym drewnie (ryc. 23):

1. inicjalny - do 4(5) lat po wyrębie, charakteryzujący się występowaniem na powierzchni cięcia pniaków sosnowych tylko pojedynczych roślin; ścianki okryte są korą, na której rosną gatunki epifityczne, pospolicie spotykane u nasady pni starych sosen;

2. intensywnego zasiedlania (inwazji) - 4(5)-10(11) lat po wyrębie, w którym 
odbywa się szybkie zarastanie drewna pniaków; dominują porosty skorupiaste (Lecidea humosa i L. granulosa - rys. 19);

3. optymalny - 10(11)-15(16) lat po wyrębie, wyróżniający się największym zróżnicowaniem flory, koegzystencją gatunków nieleśnych i leśnych; panują porosty skorupiaste oraz gatunki $\mathrm{z}$ rodzaju Cladonia o podecjach nierozgałęzionych;

4. regresji:

a. dominacji gatunków humusolubnych - 15(16)-25(30) lat po wyrębie; bardzo mały udział mają gatunki światłolubne, dominują chrobotki o podecjach rozgałęzionych (głównie Cladonia mitis) oraz humusolubne porosty i mszaki (Cladonia glauca, Cl. cenotea, Cl. digitata, Dicranum polysetum i Pleurozium schreberi);

b. terminalny - od 25(30) lat po wyrębie, w którym następuje ostateczne rozłożenie drewna pniaków i zarośnięcie ich przez gatunki runa.

Opisane wyżej stadia sukcesyjne są krótkotrwałe i mało stabilne. Flora pniaków sosnowych zależy od stopnia zmurszenia drewna, warunków świetlnych i wilgotnościowych oraz od składu florystycznego zbiorowisk, w których pniaki występują (pod słowem ,zbiorowiska” rozumiem w tym miejscu poszczególne, wyraźnie wyodrębniające się stadia sukcesji wtórnej na siedlisku Cladonio-Pinetum) (ryc. 16, 17, 19, 23).

W badanym terenie znaleziono 35 gatunków porostów będących epifitami Pinus silvestris. Większość $\mathrm{z}$ nich występuje rzadko lub w niewielkich ilościach (tab. 8). Do najpospolitszych i najobficiej rosnących należą: Hypogymnia physodes, Lecanora conizaea, Lepraria aeruginosa, Pseudevernia furfuracea, Parmeliopsis ambigua, Bacidia chlorococca i Lecidea scalaris. Flora epifityczna sosen zmienia się wraz ze wzrostem drzew: rośnie liczba gatunków i ich pokrywanie (ryc. 15), coraz większą przewagę zyskują porosty o plechach listkowatych (ryc. 14), ustępują gatunki przywiązane do cienkich gałązek (Bacidia chlorococca, Cetraria sepincola, Lecanora conizaeoides i L. umbrina) (tab. 8).

Dominację porostów w borze chrobotkowym potwierdziły badania stanu biomasy runa. Ich wyniki opublikowano w oddzielnym opracowaniu (F a 1 t y n o w ic z 1983/1985). Stwierdzono, że $85 \%$ biomasy całkowitej tworzą porosty i mszaki, przy czym główną rolę odgrywają te pierwsze, a przede wszystkim Cladonia sylvatica (tab. 15). Oprócz niej większe znaczenie mają tylko dwa gatunki: Dicranum polysetum i Calluna vulgaris.

Analiza materiału zebranego w trakcie badań biomasy pozwoliła na wyciągnięcie następujących wniosków metodycznych:

a. najbardziej zmienna jest cecha „biomasa gatunku”, o czym świadczą bardzo szerokie przedziały ufności i wysoki współczynnik zmienności; przyczyną tego jest zbyt mała liczba replikacji. Jednakże analiza większego materiału nastręcza istotne trudności techniczne;

b. konieczne jest w przyszłości określenie charakteru zależności między biomasą a powierzchnią: czy ma ona charakter liniowy, czy logarytmiczno-potęgowy. Pozwoli to na zwiększenie wiarygodności uzyskiwanych wyników.

Bór chrobotkowy jest typem zbiorowiska, które w dużej mierze powstało jako wynik okresowego użytkowania siedlisk przez rolnictwo i rabunkowej gospodarki leśnej, przy braku działań kompensujących ubytek materii organicznej. Różnorodne zabiegi gospodarcze w sposób istotny wpływają na skład, strukturę i dynamikę fitocenoz. Zmiany florystyczne, wywołane zastosowaniem nawożenia mineralnego, zachodzą na tle przemian sukcesyjnych, co znacznie utrudnia interpretację wyników. Ponadto wpływ nawozów mineralnych na porosty do tej pory nie był przedmiotem studiów. W światowej literaturze lichenologicznej i ekologicznej brak na ten temat jakiejkolwiek wzmianki, co uniemożliwia porównanie uzyskanych wyników. 
Rezultaty badań nad wpływem nawożenia mineralnego na runo Cladonio-Pinetum pozwalają na określenie $\mathrm{z}$ dużym prawdopodobieństwem kierunku przekształceń roślinności na siedlisku boru suchego po zastosowaniu tego zabiegu. Zaobserwowane zmiany we florze polegają przede wszystkim na:

- pojawieniu się w nawożonych uprawach Senecio silvaticus i w stosunkowo dużych ilościach roślin murawowych: Spergula vernalis, Corynephorus canescens i Rumex acetosella (ryc. 28, tab. 14);

- zwiększeniu się na powierzchniach nawożonych udziału roślin naczyniowych, glównie Deschampsia flexuosa (ryc. 28);

- zwiększeniu się w układach nawożonych udziału mszaków, a zmniejszeniu porostów (ryc. 27);

- zmniejszeniu się w uprawach i młodnikach nawożonych liczby gatunków roślin zarodnikowych (ryc. 30).

Powyższe fakty sugerują możliwość przejścia boru suchego w bór sucho-świeży, a nawet i świeży. Zmian takich nie można jednak spodziewać się po jednorazowym nawożeniu, którego efekty są krótkotrwałe i przemijające. Wyczerpanie wprowadzonych do gleby związków mineralnych powoduje powrót do stanu sprzed nawożenia. Już w tej chwili takie fakty, jak wyginięcie Senecio silvaticus w uprawach i ogólne zmniejszanie się pokrywania roślin naczyniowych (por. tab. 14, ryc. 26) wskazują na koniec stymulacji przez nawozy zmian w runie.

Wpływ nawożenia potwierdzają wyniki badań stanu biomasy runa boru suchego, a głównie ponad dwukrotnie większa wartość biomasy porostów w fitocenozach nienawożonych niż w nawożonych (tab. 15).

Efekty nawożenia mineralnego w badanym terenie były zupełnie nieproporcjonalne do oczekiwań. Ekonomiczna opłacalność tego zabiegu, wykonywanego w takiej formie, jak w północno-zachodniej części Borów Tucholskich, powinna być poddana weryfikacji. Przy analizie opłacalności mineralnego nawożenia lasów należy uwzględnić wpływ tego zabiegu na całe środowisko przyrodnicze, a zwłaszcza jego negatywne skutki dla kontaktowych ekosystemów wodnych i wysokotorfowiskowych (por. Fałt y nowicz, Szmeja 1978).

Innym zabiegiem hylomelioracyjnym, którego wpływ na roślinność runa analizowano w niniejszym opracowaniu, jest wprowadzenie podszytu. Wokół podsadzonych krzewów stwierdzono pojawienie się kilkudziesięciu gaturków roślin naczyniowych obcych siedliskowo (tab. 16, ryc. 32). Rośliny te, w ciągu czterech lat obserwacji, nie wykazują ekspansji, poza kilkoma gatunkami wytwarzającymi rozłogi, np. Agropyron repens, Poa pratensis, Rumex acetosella, Trifolium repens. Jak dotąd nie stwierdzono widocznego wpływu podszytu i roślin mu towarzyszących na stosunki ilościowe i jakościowe w runie boru chrobotkowego. Można jednak przypusżczać, że w miarę wzrostu krzewów, a co za tym idzie zwiększenia opadu martwej materii organicznej, niektóre $\mathrm{z}$ wymienionych wyżej roślin mogą odegrać większą rolę, a nawet zadomowić się na stałe, stając się jednym z czynników polepszających właściwości siedliska. Mogłoby to spowodować zmianę charakteru runa Cladonio-Pinetum, wyrażającą się w pierwszym rzędzie wyeliminowaniem porostów. Sugerują to również nieliczne wzmianki w literaturze (M i le ws ki 1970; Kocjan 1977).

Bardzo silnymi czynnikami degradującymi siedlisko są grabienie ściółki i wypas bydła. Stwierdzono, że w wyniku takiego prymitywnego użytkowania boru świeżego nastąpiło bardzo silne zubożenie podłoża i flory, a w efekcie zmiana zbiorowiska - powstał bór suchy w najbardziej ubogiej postaci i z mało wartościowym drzewostanem (tab. 17).

Bór chrobotkowy, mimo pozornego ubóstwa florystycznego i monotonnej fizjonomii, okazał się bardzo interesującym obiektem badawczym. Ilość problemów, 
z których każdy mógłby być odrębnym, wymagającym obszernych studiów, zagadnieniem badawczym, przekracza znacznie zakres niniejszego opracowania. Starano się jednak przedstawić możliwie szeroki ich wachlarz, aby zachęcić do badań tego typu w różnych zbiorowiskach i zwrócić uwagę na rolę takich roślin, jak porosty, dla których opracowania z zakresu ich ekologii, biologii i znaczenia fitocenotycznego nie idą $w$ parze $\mathrm{z}$ bardzo bogatą literaturą florystyczną.

Dr Wiestaw Faltynowicz Katedra Ekologii Roślin $i$ Ochrony Przyrody, Uniwersytet Gdański, ul. Czołgistów 46 81-378 Gdynia

\section{REFERENCES}

Ahti T., 1977. Lichens of the Boreal Coniferous Zone. [In:] Lichens Ecology. Ed. by M. R. D. Seaward, Academic Press, London-New York-San Francisco, pp. 145-181.

A hti T., Hepburn R. L., 1967. Preliminary studies on woodland caribou range, especially on lichen stands in Ontario. Research Report (Wildlife) 74: 1-134.

Ba c S., Ostrowski S., 1969. Podstawy leśnych melioracji wodnych. PWRiL, Warszawa.

Barkman J. J., 1969. Phytosociology and ecology of cryptogamic epiphytes. Van Gorcum and Comp. N. V., Assen.

B a u le H., Fricker C., 1973. Nawożenie drzew leśnych. PWRiL, Warszawa.

Berdowski W., 1974. Flora mchów i zbiorowiska mszaków masywu Slęży. Monogr. Bot. 45.

Boiński M., 1976. Historia lasów na obszarze Borów Tucholskich w świetle anałizy materiałów archeologiczno-historycznych. MS, Torun.

Boiński M., Gugnacka-Fiedor W., 1977. Materiały do flory Borów Tucholskich. Część I. Acta Univ. Nicolai Copernici, Biol. 20: 107-112.

Brodo I. M., 1973. Substrate ecology. [In:] The lichens. Ed. by V. Ahmadijan and M. R. Hale, Academic Press, New York-London, pp. 401-441.

B u dzbon E., unpbl. Porosty Mierzei Wiślanej. Gdynia.

Bystrek J., Bystrek J., 1972. Materiały do flory porostów okolic Suśca na Roztoczu Srodkowym. Ann. UMCS, C 27: 169-183.

Bystrek J., Górzyńska K., 1976. Gatunki rodzaju Bryopogon Link. emend. Bystr. na Lubelszczyźnie. Ann UMCS, C 31: 113-120.

Bystrek J., Ożóg K., 1974. Materiały do flory porostów okolic Krasnobrodu na Roztoczu Srodkowym. Fragm. Flor. Geobot. 29: 259-270.

Ceynowa M., Rejewski M., 1969. Roślinność jeziora Nawionek. Stud. Soc. Sc. Torunensis, D 9: 1-16.

Chojnacki J., 1974. Problem reprezentatywności strukturalnej w badaniach nad produkcją runa fitocenozy leśnej. Phytocoenosis 3: 69-112.

Ciéśliński S., 1973. Porosty Gór Swiętokrzyskich. Zesz. Przyrod., Kielce 1: 1-30.

Cieśliński S., 1978. Porosty rezerwatu Zagożdżon w Puszczy Kozienickiej. Fragm. Flor. Geobot. 24: 467-484.

Cieśliński S., 1979. Udział oraz rola diagnostyczna porostów naziemnych w zbio- 
rowiskach roślin naczyniowych Wyżyny Kielecko-Sandomierskiej i jej pobrzeży. WSP, Kielce.

Cybulko T., 1968. Reakcja borówki czarnej (Vaccinium myrtillus) rosnącej w naturalnym środowisku na mineralne nawożenie. Spraw. PTPN 80: 205-206.

Czerwiński A., 1970. Bory sosnowe północno-wschodniej Polski. Prace Komisji Biol. PTPN 33: 3-91.

Czubiński Z., 1950. Zagadnienia geobotaniczne Pomorza. Bad. Fizjogr. Pol. Zach. 2: 439-637.

Czyżewska K., 1974. Materiały do flory porostów województwa łódzkiego. Porosty rezerwatu modrzewia polskiego Trębaczew. Fragm. Flor. Geobot. 20: 243-253.

Dziabaszewski B., 1962a. Porosty wyspy Wolin ze szczególnym uwzględnieniem parku narodowego. Prace Komisji Biol. PTPN 22: 3-47.

Dziabaszewski B., 1962b. Porosty okolic Poznania na tle porostów Wielkopolski. Prace Komisji Biol. PTPN 22: 1-159.

Dzi ęc i oło o s k i W., 1963. Warunki rozwojowe drzewostanów sosnowych na niektórych glebach bielicowych. Prace Komisji Nauk Roln. i Komisji Nauk Leśn. PTPN 15: 3-68.

Ellenberg H., 1978. Der Wald als Okosystem. Eidgenössische Anstalt für das Forstliche Versuchswesen Mitteilungen 4: 385-395.

Fabiszewski J., 1964. Materiały do flory porostów północnej części Wysoczyzny Siedleckiej. Fragm. Flor. Geobot. 10: 249-262.

Fabiszewski J., 1975. East Canadian peat bog ecosystems and the biological role of their lichens. Phytocoenosis 4: 1-94.

Faliński J. B., 1980. Changes in the sex- and age-ratio in populations of pioneer dioecious woody species (Juniperus, Populus, Salix) in connection with the course of vegetation succession in abandoned farmlands. Ekol. Pol. 28: 327-365.

Fałtynowicz W., 1978. Rzadsze gatunki roślin naczyniowych nadleśnictwa Przymuszewo w Borach Tucholskich. Bad. Fizjogr. Pol. Zach., B 30: 193-197.

F ałtynowicz W., 1980. Porosty północno-zachodniej części Borów Tucholskich. Fragm. Flor. Geobot. 26: 81-102.

Fałtynowicz W., 1981. Umbilicaria deusta (L.) Baumg. i Collema flaccidum (Ach.) Ach. na Suwalszczyźnie. Fragm. Flor. Geobot. 27: 523-525.

Fałtynowicz W., 1983. Polska bibliografia lichenologiczna. Inst. Bot. PAN, Kraków-Wrocław.

Fałtynowicz W., 1983/1985. Zmiany biomasy runa boru chrobotkowego (Cladonio-Pinetum) pod wpływem nawożenia mineralnego (doniesienie naukowe). Zesz. Nauk. Wydz. BiNoZ UG, Biol. 4: 109-121.

Fałtynowicz W., 1982. Porosty Bielawskiego-Błota - stan aktualny i analiza zmian po trzydziestu latach dewastacji torfowiska. Fragm. Flor. Geobot., in press.

Fałtynowicz W., Budzbon E., 1982. Drugie stanowisko Cetraria nivalis (L.) Ach. na niżu polskim. Fragm. Flor. Geobot., in press.

Fałtynowicz W., Szmeja J., 1978. O potrzebie utworzenia stref ochronnych wokół jezior lobeliowych. Chrońmy Przyr. Ojcz. 34: 5-17.

Fałtynowicz W., Tobolewski Z., 1980. Cetraria nivalis (L.) Ach. w Borach Tucholskich (Pomorze Zachodnie). Fragm. Flor. Geobot. 26: 341-347.

Fiedler H. J., H unger W., 1963. Ưber den Einfluss einer Kalkdüngung auf Vorkommen, Wachstum und Nährelementgehalt höherer Pilze in Fichtenbestand. Arch. Forstw. 12: 936-962.

Fijałkowski D., 1971. Zmiany w lasach Lubelszczyzny wynikłe ze stosowania 
obowiązujących zasad hodowlanych w Polsce. Folia Soc. Sc. Lublinensis, B 13: 49-53.

Fis cher F., 1978. Forstwirtschaft und Landschaftsschutz. Eidgenössische Anstalt für das Forstliche Versuchswesen Mitteilungen 4: 519-528.

F o g K., 1977. Studies on decomposing wooden stumps. I. The microflora of heardwood stumps. Pedobiologia 17: 240-261.

Frey E., 1959. Die Flechtenflora und -vegetation des National-Parkes im Unterengadin. II Teil: Die Entwicklung der Flechtenvegetation auf photogrammetrisch kontrollierten Dauerflächen. Ergeb. wiss. Unters. Schweiz. Nat.-Parks 6: 241-319.

Fudała A., 1980. Rozwój gradacji brudnicy mniszki i innych szkodników pierwotnych w latach 1977-80 na terenie Borów Tucholskich i w lasach regionu gdańskiego oraz ich zwalczanie. MS.

Ga l o n R., 1953. Morfologia doliny i zandru Brdy. Stud. Soc. Sc. Torunensis 1: $1-56$.

Ga loux A., 1979. La fertilization annuelle continue dans les peuplements résineux. Bull. Soc. Roy. For. Belg. 2: 67-74.

G l a n c K., 1965. Ugrupowania porostów epifitycznych w zespołach leśnych nadleśnictwa doświadczalnego Zielonka pod Poznaniem. Prace Komisji Biol. PTPN 24: $3-59$.

G l a n c K., Ka puściński R., Król I., 1971. Flora porostów okręgu baryckiego w Krainie Wielkopolsko-Kujawskiej. Prace Komisji Nauk Roln. i Komisji Nauk Leśn. PTPN 32: 23-38.

Glanc K., Tobolewski Z., 1960. Porosty Bieszczadów Zachodnich. Prace Komisji Biol. PTPN 21: 1-107.

G1 a tzel G., 1979. Standortsdegradationen als Folge mechanisierter Holzernte. Allg. Forstzeitung 12: 372-373.

Glixelli S., Prosiński S., 1951. Z badań nad składem chemicznym drewna niektórych drzew krajowych. Prace Komisji Mat.-Przyr. PTPN 6: 1-10.

Grodziński W., 1958. The succession of small mammal communities on an overgrown clearing and landslip in the Western Carpathians. Bull. Acad. Pol. Sc., Sc. Biol. 6.

Grzywacz A., 1976. Występowanie grzybów patogenicznych w drzewostanach nadl. Olek będących pod wpływem przemysłowych zanieczyszczeń powietrza. Folia Forest. Pol., A 22: 149-163.

Guzikowa M., La tocha M., Pancer-Kotejowa E., Zarzycki K., 1976. The effect of fertilization on a pine forest ecosystem in an industrial region. III. Herbs. Ekel. Pol. 24: 307-318.

H a le M. E., 1974. The biology of lichens. Edward Arnold Ltd., London.

H a 1 i c z B., 1959. Badania statystyczno-florystyczne nad rozmieszczeniem nadrzewnych porostów okolic Łodzi. Łódzkie Tow. Nauk. 60: 5-40.

Halicz B., Godlewski M., 1968. Flora i stosunki fitosocjologiczne naziemnych porostów Zielonej Puszczy Kurpiowskiej. Łódzkie Tow. Nauk. 104: 8-46.

Heinrich Z., Wojewoda W., 1976. The effect of fertilization on a pine forest ecosystem in an industrial region. IV. Macromycetes. Ekol. Pol. 24: 319-330.

Henningsson B., Lündström H., 1970. The influence of lichens, lichen extracts and usnic acid on wood destroying fungi. Material und Organismen 5: $1-31$.

Holmen H., 1978. Zur Forstdüngung in Skandinavien. Allg. Forstzeitschr. 48: 1413.

Il mużyński E., 1969. Szczegółowa hodowla lasu. PWRiL, Warszawa.

I zydorek I., 1978. Materiały do flory porostów nadleśnictwa Smolarz. Fragm. Flor. Geobot. 24: 147-156. 
Kajak Z., Prończuk J., 1979. Zmiany środowiska rolniczo-leśnego w Polsce w perspektywie roku 2000. Zesz. Probl. Post. Nauk Roln. 217: 11-28.

K a we cki W., 1939. Lasy Żywiecczyzny, ich teraźniejszość i przeszłość (zarys monograficzny). PAU, Prace Roln.-Leśn. 35: 1-171.

Kennel E.; Franz F., 1977. Die Zuwachsleistung von Kiefernbeständen nach grossflächiger Flugzeugdüngung mit Kalkamonsalpeter im Forstamt Weiden in der Oberpfalz. Forstarchiv. 10: 206-210.

Kershaw K. A., 1964. Preliminary observations on the distribution and ecology of epiphytic lichens in Wales. Lichenologist 2: 263-276.

Kępczyński K., 1965. Szata roślinna Wysoczyzny Dobrzyńskiej. UMK, Toruń. K iszk a J., 1964. Porosty Kotliny Sandomierskiej. Część I: Porosty Okręgu Puszczy Niepołomickiej. Fragm. Flor. Geobot. 10: 527-564.

K i s z k a J., 1967a. Porosty Beskidu Sląskiego. Roczn. Nauk.-Dydakt. WSP w Krakowie, 28, Prace z bot. 1: 5-91.

Kiszka J., 1967b. Porosty Pasma Gubałówki. Fragm. Flor. Geobot. 13: 419-446. Kiszka J., 1979. Flora porostów (Lichenes) okolic Pustyni Błędowskiej. Studia Ośrodka Dokumentacji Fizjograficznej 7: 349-377.

Klement O., 1955. Prodromus der mitteleuropäischen Flechtengesellschaften. Feddes Repert. Spec. Nov. Reg. Veget. 117: 1-192.

K o c jan H., 1977. Wpływ przygotowania gleby i nawożenia na udatność i wzrost sosny zwyczajnej na siedlisku boru suchego. Prace Komisji Nauk Roln. i Komisji Nauk Leśn. PTPN 44: 71-80.

K o e hler W., 1971. Hylopatologiczna charakterystyka lasów Polski. PWRiL, Warszawa.

K ondracki J., 1981. Geografia fizyczna Polski. PWN, Warszawa.

Kosturkiewicz A., 1964. Vliyanie urovnia pochvenno-gruntovykh vod na rost sosnovogo molodniaka. Ekol. Pol. A 12: 125-146.

Kowalkowski A., 1979. Perspektywy mineralnego nawożenia lasu i jego rola w kształtowaniu środowiska. Zesz. Probl. Post. Nauk Roln. 217: 11-28.

K ozak K., 1967. Bory nadleśnictwa Parczew. Ann. UMCS, C 21: 313-342.

Kozik R., 1977. Porosty (Lichenes) Pogórza Rożnowsko-Ciężkowickiego. Fragm. Flor. Geobot. 23: 215-252.

Krapfen ba uer A., 1977. Der forstliche Standort und dessen Belastberkeit. Allg. Forstzeitung 12: 332-335.

Kreutzer K., 1979. Okologische Fragen zur Voltbaumernte. Forstwis. Clb. 6: 298-308.

Krotoska T., Tobolewski Z., 1980. Zbiorowisko naziemnych porostów psammofilnych w Słowińskim Parku Narodowym. Bad. Fizjogr. Pol. Zach., B (Bot.) 31: 53-63.

Król S., 1963. Zmienność fenotypowa Calluna vulgaris (L.) Salisb. w zespołach borowych związku Vaccinio-Piceion. Prace Komisji Nauk Roln. i Komisji Nauk Leśn. PTPN 15: 69-114.

Krzyszkowski J., 1974. Melioracje agrotechniczne w leśnictwie. PWRiL, Warszawa.

Kwiatkowska A. J., Dudziec J., 1974. Zmienność przestrzenna stanu biomasy części nadziemnej runa w rezerwacie "Grabowy" w Puszczy Kampinoskiej. Phytocoenosis 3: 43-68.

K wi e cień K., 1979. Warunki klimatyczne. [In:] Pojezierze Kaszubskie. Ed. by B. Augustowski, Ossolineum, Gdańsk, pp. 95-120.

Lambert J. D. H., Ma y cock P. F., 1968. The ecology of terricolous lichens of the Northern Conifer-Hardwood forests of central Eastern Canada. Can. J. Bot. 46: 1043-1078. 
Leibundgut H., 1972. Pielęgnowanie drzewostanów. PWRiL, Warszawa.

Li nnemann G., 1964. Mykorrhiza und Düngung. AFJZ 135(9).

Lis owski S., Szafrański F., Tobolski K., 1965. Interesujące torfowisko nad jeziorem Stawek w powiecie chojnickim (woj. bydgoskie). Bad. Fizjogr. Pol. Zach. 16: 199-204.

Lisowski S., Szafrański F., Tobolski K., 1966a-1970. Materiały do flory powiatu chojnickiego (Pomorze Zachodnie). Bad. Fizjogr. Pol. Zach.: I - 1966a, 18: 251-258; II - 1967a, 20: 87-101; III - 1969, 22: 161-165; IV - 1970, B 23: 171-204.

Lisowski S., Szafrański F., Tobolski K., 1966b-1967b. Notatki bryologiczne z powiatu chojnickiego (Pomorze Zachodnie). Bad. Fizjogr. Pol. Zach.: I - 1966b, 18: 259-261; II - 1967b, 20: 163-168.

L ündström H., 1970. Epixyls on treated wooden posts at Bogesund. Medd. Reports 101: 1-7.

Luścińska M., 1979. Structure of epiphytic algal communities of the Lobelialakes in the region of Bory Tucholskie (Poland). Arch. Hydrobiol., Supp. 56: 324-338.

Ławrynowicz J., 1964. Jeziora lobeliowe w północnej części powiatu chojnickiego. Bad. Fizjogr. Pol. Zach. 14: 185-189.

Ławrynowicz J., 1965. Jeziora lobeliowe we wschodniej i północno-wschodniej części powiatu chojnickiego. Bad. Fizjogr. Pol. Zach. 16: 195-197.

Maikawa E., Kershaw K. A., 1976. Studies on lichen-dominated systems. XIX. The postfire recovery sequence of black-spruce lichen woodland in the Abitae Lake Region, N.W.T. Can. J. Bot. 54: 2679-2687.

Malicki J., 1965. Wpływ kwasów porostowych na mikroorganizmy glebowe. Część I. Wypłukiwanie kwasów do gleby. Ann. UMCS, C 20: 239-248.

Malicki J., 1967. Wpływ kwasów porostowych na mikroorganizmy glebowe. Część II. Wpływ wyciągów wodnych z gatunków Cladonia na bakterie glebowe. Ann. UMCS, C 22: 159-163.

Malicki J., 1970. Wpływ kwasów porostowych na mikroorganizmy glebowe. Część III. Wpływ gatunków z rodzaju Cladonia na stosunki bakteryjne w glebie zespołu Peucedano-Pinetum cladonietosum. Ann. UMCS, C 25: 75-80.

Malysheva T. V., 1981. The reaction of some soil mosses on fertilizers. Ekologia 6: 47-53.

Malysheva T. V., Shmidt V. M., Golubkova N. S., 1980. The lichens of Tataria. II. The ecological distribution of lichens according to substrates. On substrate role in geographical distribution of lichens. Vestn. Leningradskogo Univ., 15, Biol. 3: 45-55.

Markowski R., 1971. Regeneracja acidofilnych zbiorowisk leśnych na porębach wysp Wolina i południowo-wschodniego Uznamu. Prace Komisji Biol. PTPN 35: 1-28.

Markowski R., 1974. Zręby zupełne jako czynnik degeneracji niektórych fitocenoz leśnych. Phytocoenosis 3: 215-226.

M a r kowski R., 1982. Sukcesja wtórna roślinności na porębach lasów liściastych. Prace Komisji Biol. PTPN 61: 3-76.

Matuszkiewicz W., Matuszkiewicz J., 1973. Przegląd fitosocjologiczny zbiorowisk leśnych Polski. Cz. 2. Bory sosnowe. Phytocoenosis 2: 273-356.

Milewski J., 1970. Podszyty w litych drzewostanach sosnowych. Sylwan 114: 63-72.

Moberg R., 1977. The lichen genus Physcia and allied genera in Fennoscandia. Symb. Bot. Upsal. 22: 1-108.

Molenda T., 1963. Problem wzrostu produktywności lasów Polski. Sylwan 107: 13-26. 
M otyka J., 1960. Porosty (Lichenes). 5(1). Parmeliaceae. Flora polska. Rośliny zarodnikowe Polski i ziem ościennych. PWN, Warszawa.

Motyka J., 1962. Porosty (Lichenes). 5(2). Usneaceae. Flora polska. Rośliny zarodnikowe Polski i ziem ościennych. PWN, Warszawa.

M o ty ka J., 1964. Porosty (Lichenes). 3(2). Cladoniaceae. Flora polska. Rośliny . zarodnikowe Polski i ziem ościennych. PWN, Warszawa.

M o w śzowicz J., 1956. Roślinność dolnych warstw borów sosnowych na pogorzeliskach. Sylwan, A 100: 42-49.

Mucha W., Sienkiewicz A., Szymańska M., 1979. Dotychczasowe efekty i perspektywy nawożenia w Puszczy Noteckiej. Sylwan 123: 39-48.

Muhle H., Le Blanc F., 1975. Bryophyte and lichen succession on decaying logs. I. Analyses along on evaporational gradient in eastern Canada. J. Hattori Bot. Lab. 39: 1-33.

Nowak J., 1961. Porosty Wyżyny (Jury) Krakowsko-Częstochowskiej. Monogr. Bot. 11(2): 1-126.

N owa k J., 1967. Porosty Wyżyny Wieluńskiej. Acta Mycol. 3: 209-242.

Nowak J., Tobolewski Z., 1975. Porosty polskie. PWN, Warszawa-Poznań.

Nowotarska E., 1976. Porosty Puszczy Dulowskiej. Zesz. Nauk. UJ, Prace Bot. 4: 143-157.

O bmiński Z., 1970. Zarys ekologii. [In:] Sosna zwyczajna Pinus silvestris L. Ed. by S. Białobok. PWN, Warszawa-Poznań, pp. 152-231.

O b m ińs ki Z., 1977. Ekologia lasu. PWN, Warszawa.

Ochsner F., 1928. Studien über die Epiphyten-Vegetation der Schweiz. Jahrb. Naturf. Ges. St. Gallen 63: 1-108.

Ochyra R., Szmajda P., 1978. An annotated list of Polish mosses. Fragm. Flor. Geobot. 24: 93-145.

Oktaba W., 1976. Elementy statystyki matematycznej i metodyka doświadczalnictwa. PWN, Warszawa.

Ola c zek R., 1972. Formy antropogenicznej degeneracji leśnych zbiorowisk roślinnych w krajobrazie rolniczym Polski niżowej. Wyd. Uniw. Łódzkiego.

Ole ch M., 1973. Porosty Beskidu Sądeckiego. Zesz. Näuk. UJ, Prace Bot. 1: 87192.

Olszowski J., 1976a. The effect of fertilization on a pine forest ecosystem in an industrial region. I. Forest stand volume increment. Ekol. Pol. 24: 285297.

Olszowski J., 1976b. The effect of fertilization on a pine forest ecosystem in an industrial region. V. Chemical properties of the soils. Ekol. Pol. 24: 331-344.

O1szowski J., 1976c. The effect of fertilization on a pine forest ecosystem in an industrial region. VI. Biological activity of the soils. Ekol. Pol. 24: 345-358.

O lszowski J., 1976d. The effect of fertilization on a pine forest ecosystem in an industrial region. VII. Summary of the studies. Ekol. Pol. 24: 359-363.

Olszowski J., Warteresiewicz M., 1976. The effect of fertilization on a pine forest ecosystem in an industrial region. II. Sulphur content and some morphological characters of the needles. Ekol. Pol. 24: 299-306.

Ordyczyńska B., 1973. Porosty lasów nadleśnictwa Leżajsk w województwie rzeszowskim. Fragm. Flor. Geobot. 19: 101-118.

Orłoś H., 1961. Grzyby w środowisku leśnym, podział na grupy ekologiczne i ocena funkcji ekologicznej. Sylwan 105: 61-68.

P a w ła t H., 1974. Wpływ uwilgotnienia i nawożenia na dynamikę przyrostu, plon i skład florystyczny łąki madowej. Roczn. Nauk Roln., D, Monogr. 156: 1-103.

Pawłowski B., 1972. Skład i budowa zbiorowisk roślinnych oraz metody ich badania. [In:] Szata roślinna Polski. Ed. by W. Szafer and K. Zarzycki. PWN, Warszawa, 1: 237-268. 
Petersen P. M., 1970. Changes of the fungus flora after treatment with various chemicals. Bot. Tidsskr. 65: 264-280.

Prosiński S., 1969. Chemia drewna. PWRiL, Warszawa.

Prusinkiewicz Z., 1973. Gleby. [In:] Województwo bydgoskie. Krajobraz, dzieje, kultura, gospodarka. PWN, Poznań, pp. 47-57.

Puchalski T., Prusinkiewicz Z., 1975. Ekologiczne podstawy siedliskoznawstwa leśnego. PWRiL, Warszawa.

R a ma u t J.-L., C orvis i e r M., 1975. Effect inhibiteurs des extrains de Cladonia impexa Harm., C. gracilis (L.) Willd. et Cornicularia muricata (Ach.) Ach. sur la germination des graines de Pinus silvestris L. Oecol. Plant. 10: 295-299.

Rejewski M., 1981. Roślinność jezior regionu Laski w Borach Tucholskich. UMK, Toruń.

Reyment-Grochowska I., 1950a. Wątrobowce. PZWS, Warszawa.

Reyment-Groch ow ska I., 1950b. Czynniki ekologiczne i rozmieszczenie geograficzne wątrobowców (Hepaticeae) Beskidu Sląskiego. Prace Biol. 2: 3-71.

Romer E., 1949. Regiony klimatyczne Polski. Prace Wrock. Tow. Nauk., B 16: 1-26.

Rydin J., 1978. Walddüngung in Skandinavien am Beispiel der Schwedischen Staatsforstverwaltung. Allg. Forestzeitschr. 15: 420-422.

Rydzak J., 1955. Wpływ małych miast na florę porostów. Cz. IV. LubelszczyznaKieleckie-Podlasie. Puławy-Zamość-Busko-Siedlce-Białowieża. Ann. UMCS, C 10: 321-398.

Rydzak J., 1961. Tree lichens in the forest communities of the Białowieża National Park. Ann. UMCS, 16: 17-47.

R y dzak J., 1969a. Badania nad stanem ilościowym flory porostów nadrzewnych Puszczy Białowieskiej i Puszczy Ladzkiej. Ann. UMCS, C 24: 65-72.

R y dzak J., 1969b. Badania nad stanem ilościowym flory porostów nadrzewnych na Roztoczu. Ann. UMCS, C 24: 41-63.

Rydzak J., 1970. Flora i ekologia porostów drzew przydrożnych. Ann. UMCS, C 25: 149-157.

Rydzak J., Sa łata B., 1970. Badania nad stanem ilościowym flory porostów nadrzewnych Puszczy Solskiej. Ann. UMCS, C 25: 159-165.

Rydzak J., Zabińska B., 1972. Badania nad szybkością wzrostu porostów. Część III. Ann. UMCS, C 27: 151-158.

Rykowski K., Sierota Z., 1972. Wstępna analiza mikologiczna drewna, korzeni i pniaków sosnowych na gruntach porolnych. Prace IBL 531: 3-19.

S a lo K., 1979. Mushrooms and mushroom yield on transitional peat-land in central Finland. Ann. Bot. Fenn. 16: 181-192.

Sandstede H., 1931. Die Gattung Cladonia. [In:] Rabenhorst's KryptogamenFlora von Deutschland, Osterreich und der Schweiz. 9.4, 2: 1-531.

S camoni A., 1967. Wstęp do fitosocjologii praktycznej. PWRiL, Warszawa.

Schulz-Korth K., 1931. Die Flechtenvegetation der Mark Brandenburg. Repert. Spec. Nov. Reg. Veget. 117: 1-192.

S cotter G. W., 1963. Growth rates of Cladonia alpestris, C. mitis and C. rangiferina in the Taltson River region, N.W.T. Can. J. Bot. 41: 1199-2002.

S cotter G. W., 1964. Effects of forest fires on the winter range of barrenground carribou in northern Sask. Can. Wildl. Serv. Manage. Bull. 1, 18.

Shure D. J., Ragsdale H. L., 1977. Patterns of primary succession on granits outcrop surfaces. Ecology 58: 993-1006.

S o k ołowski A. W., 1961. Badania mikroklimatyczne na zrębie zupełnym w Puszczy Białowieskiej. Ekol. Pol., A 9: 259-285. 
Sokołowski A. W., 1963. Zespoły leśne południowo-wschodniej części Niziny Mazowiecko-Podlaskiej. Monogr. Bot. 16.

S ok ołowski A. W., 1965. Zespoły leśne nadleśnictwa Laska w Borach Tucholskich. Fragm. Flor. Geobot. 9: 97-119.

Sokołowski A. W., 1970a. Charakterystyka fitosocjologiczna i stanowisko systematyczne borów chrobotkowych Polski. Prace IBL 368: 3-13.

S ok ołowski A. W., 1970b. Fitosocjologiczna charakterystyka zbiorowisk roślinnych nadleśnictwa Józefów koło Biłgoraja. Prace IBL 370: 65-130.

S ok ołowski A. W., 1972. Gospodarcze użytkowanie lasu jako główny czynnik synantropizacji zbiorowisk leśnych. Phytocoenosis 1: 211-216.

Sokołowski A. W., 1976. Charakterystyka fitosocjologiczna lasów Wysoczyzny Drohickiej. Prace IBL 513: 3-46.

Sokołowski A. W., 1980. Zbiorowiska leśne północno-wschodniej Polski. Monogr. Bot. 60 .

Sosnowski J., 1977. Problem oceny szkód wyrządzonych przez środki zrywkowe. Zesz. Nauk. AR w Krakowie, Leśn. 10: 89-98.

Strzałkowski A., Sliżyński A., 1978. Matematyczne metody opracowywania wyników pomiarów. PWN, Warszawa.

Sulma T., 1935. Beiträge zur Kenntnis der Flechtenflora des Lubliner Hügellandes. Acta Soc. Bot. Pol. 12: 39-67.

Surmiński J., 1970. Właściwości techniczne i możliwości użytkowania. [In:] Sosna zwyczajna Pinus silvestris L. Ed. by S. Białobok, PWN, Warszawa-Poznań, pp. 309-331.

Sz a f er W., 1972. Szata roślinna Polski niżowej. [In:] Szata roślinna Polski. Ed. by W. Szafer i K. Zarzycki. PWN, Warszawa, 2: 17-188.

Szafer W., Kulczyński S., Pawłowski B., 1969. Rośliny polskie. PWN, Warszawa.

Szodfridt J., 1980. Fertilization on forest and the vegetation. Acta Bot. Acad. Sc. Hungaricae 26: 203-207.

Szujecki A., 1976. Wpływ rębni zupełnej na entomofaunę glebową. Folia Forest. Pol., A 22: 49-58.

Szweykowski J., 1953. Mszaki Gór Stołowych. Cz. I. Wątrobowce (Hepaticeae). Prace Komisji Biol. PTPN 14: 1-133.

Sla ski K., 1951. Zasięg lasów Pomorza w ostatnim tysiącleciu. Prz. Zach. 5: 207-263.

Ties zen L. L. (ed.), 1978. Vegetation and production ecology of an Alaskan Arctic Tundra. Ecol. Stud. 29.

Tobolewski Z., 1952. Porosty epifityczne okolic Łagowa ze szczególnym uwzględnieniem flory buka. Prace Komisji Biol. PTPN 13: 1-24.

Tobolewski Z., 1955. Porosty Gór Stolowych. Prace Komisji Biol. PTPN 16: 1-98.

Tobolewski Z., 1958. Porosty Pienin. Prace Komisji Biol. PTPN 17: 1-124.

Tobolewski Z., 1963. Materiały do znajomości borów chrobotkowych północnozachodniej Polski. Bad. Fizjogr. Pol. Zach. 12: 193-212.

Tobolewski Z., Kupczyk B., 1976. Porosty (Lichenes). 3. Atlas rozmieszczenia roślin zarodnikowych w Polsce, III. PWN, Warszawa-Poznań.

Tobolski K., 1975/1976. Zarys historii roślinności powiatu chojnickiego w czasie ostatnich 12 tysięcy lat. Zeszyty Chojnickie 7: 1-18.

Toborowicz K., 1976. Porosty miasta Kielc i najbliższej okolicy. Fragm. Flor. Geobot. 22: 575-603. 
T omanek J., 1955. Klimatologiczne i hydrologiczne znaczenie lasów. Sylwan 99: 203-214.

Trampler T., 1979. Sposób zagospodarowania lasu i jego wielostronne funkcje obecnie i w perspektywie do 2000 roku. Zesz. Probl. Post. Nauk. Roln. 217: 63-82.

Tyszkiewiczowa J., 1935. Badania nad występowaniem porostów nadrzewnych w lasach północno-wschodniej części wyżyny Kielecko-Sandomierskiej. Planta Pol. 3.

Vainshtein E. A., Tolpysheva T. J., 1975. On the influence of lichens extracts on higher plants. Bot. Zhurn. 60: 1004-1011.

Wa lter H., 1955. Die Klimadiagramme als Mittel zur Beurteilung der Klimaverhältnisse für ökologische und landwirtschaftliche Zwecke. Ber. Deutsch. Bot. Ges. 68: 331-344.

Wa rmińska B., 1973. Materiały do flory porostów nadleśnictwa Kosobudy. Fragm. Flor. Geobot. 19: 91-100.

W i ąck o wski S., 1957. Entomofauna pniaków sosnowych w zależności od wieku i rozmiaru pniaka. Ekol. Pol., A 5: 13-140.

W i e lgolaski F. E. (ed.), 1975. Fennoscandian tundra ecosystems. Part 1. Plants and microorganisms. Ecol. Stud. 16.

W ł oczewski T., 1968. Ogólna hodowla lasu. PWRiL, Warszawa.

Wojterski T., 1964. Bory sosnowe na wydmach nadmorskich na polskim wybrzeżu. Prace Komisji Biol. PTPN 28: 3-215.

Z a ręba R., 1976. Zmiany w szacie leśnej Polski oraz w składzie botanicznym cenoz leśnych wywołane procesami gospodarczymi. Zesz. Probl. Post. Nauk Roln. 177: 349-367.

Zi eli ńska J., 1967. Porosty Puszczy Kampinoskiej. Monogr. Bot. 24: 1-122.

Zimny H., 1966. Fitomelioracja lekkich gleb leśnych jako czynnik wzmożenia produktywności i poprawy wartości produkcyjnej siedlisk. Ekol. Pol., B 12: 211-229.

Z a b k o-Potopowicz A., 1954. Zagadnienie lasów w Polsce przed rozbiorami od schyłku XV do połowy XVIII wieku. Sylwan 97: 364-388. 